\section{UKCPR}

University of Kentucky

Center for
DP 2009-03

\section{Discussion Paper Series}

ISSN: 1936-9379

\title{
Down from the mountain: Skill upgrading and wages in Appalachia
}

\author{
Christopher Bollinger \\ University of Kentucky \\ Department of Economics \\ James P. Ziliak \\ University of Kentucky \\ Department of Economics \\ Center for Poverty Research \\ Kenneth R. Troske \\ University of Kentucky \\ Department of Economics \\ Center for Business and Economic Research
}

\section{May 2009}

\section{Preferred citation}

Bollinger, C., Ziliak, J., and Troske, K. (2009, May). Down from the mountain: Skill upgrading and wages in Appalachia. University of Kentucky Center for Poverty Research Discussion Paper Series, DP2009-03.

Retrieved [Date] from http://www.ukcpr.org/Publications/DP2009-03.pdf.

\section{Author correspondence}

James P. Ziliak, Department of Economics, 335S Gatton Building, University of Kentucky, Lexington, KY 40506-0034; Email: jziliak@uky.edu. We are grateful to Ken Sanford for excellent research assistance. We received many helpful comments on earlier versions of this paper from seminar participants at the Brookings Institution, Georgetown University, Georgia State University, Thirteenth Annual Society of Labor Economists Meetings, the 2008 Midwest Economics Association Meetings, University of California at San Diego, University College Dublin, University College London, and Queens University. This project was funded in part by a grant to the Center for Poverty Research from the Federal Reserve Bank of Cleveland. The opinions expressed herein are those of the authors and do not necessarily reflect the views of the Federal Reserve or any other sponsoring agency. 


\begin{abstract}
Despite evidence that skilled labor is increasingly concentrated in cities, whether regional wage inequality is predominantly due to differences in skill levels or returns is unknown. We compare Appalachia, with its wide mix of urban and rural areas, to other parts of the U.S., and find that gaps in both skill levels and returns account for the lack of high wage male workers. For women, skill shortages are important across the distribution. Because rural wage gaps are insignificant, our results suggest that widening wage inequality between Appalachia and the rest of the U.S. owes to a shortage of skilled cities.
\end{abstract}

The emerging consensus in the vast wage inequality literature seems to be that growth in inequality in the United States was most pronounced in the 1980s and was largely the result of changes in the demand for skilled workers, coupled with some important institutional changes such as the decline in unionization and the real value of the minimum wage (Bound and Johnson 1992; Katz and Murphy 1992; Juhn, Murphy, and Pierce 1993; DiNardo, Fortin, and Lemieux 1996; Lee 1999; Card and DiNardo 2002). The causes behind the growth in inequality since 1990 are less clear. Some argue that the increase is due to changes in the composition of the workforce towards more experienced and more educated workers (e.g., Lemieux 2006), while others argue it is concentrated in the upper tail of the distribution resulting in a polarization of the U.S. labor market (e.g. Autor, Katz and Kearney 2005, 2008).

The inequality literature, however, has been surprisingly silent on wage differentials among workers within and between regions (Moretti 2008). This is despite the fact that there is evidence that more skilled workers tend to live in cities, that the difference in skills between cities and rural areas has been growing recently (Glaeser and Saiz 2003; Moretti 2004), and that the returns to skills have been growing within cities (Chung, Clark and Kim 2009).

We begin to fill this gap in the literature by comparing the movement of wages within the Appalachian region of the United States and the rest of the country. In particular, we study whether the widening wage gap between Appalachia and the rest of the country is due to changes in skill levels, divergence in the returns to skill, or both. Our focus on Appalachia is motivated by several factors related to inequality trends. The Appalachian region has historically had lower levels of skilled labor and income relative to the rest of the country, which some researchers claim has resulted in a 'poverty trap’ (Harrington 1962; Caudill 1962; Duncan 1999; Easterly 2001; Eller 2008). This has lead policy makers to focus extensive resources on the region in an effort to raise the levels of education and income in the area. Appalachia was the focal point for much of the legislation underlying the 'War on Poverty' and, since the mid 1960s, has been a 
well defined zone of economic activity. However, despite all of these efforts, Appalachia still lags behind the rest of the country in educational achievement and income.

While the Appalachian region has long been the focus of policy makers, it has received relatively little attention from economists (Black, Daniel, and Sanders 2002; Black and Sanders 2004). This is unfortunate since knowledge of how regional differences in skill levels and returns to skill translate into regional differentials in wages is essential to a better understanding of widening inequality in general, as well as for more targeted policy prescriptions for regional economic development (Glaeser and Gottlieb 2008). This seems particularly salient for regions with persistently low levels of income. Parente and Prescott (2005) argue that a country starts to experience sustained increases in incomes when the country's capacity to effectively use modern technological resources reaches a critical threshold. To the extent that their framework is applicable to regions within the United States, the implication of recent technological change, which favors a college-educated workforce, is that persistent income differentials will continue in regions such as Appalachia until these residents close the college-completion gap, assuming the return to such investment is at least as high as the return outside the region.

To identify the reasons for wage differences we estimate human-capital wage equations for men and women that admit region-specific heterogeneity in the returns to observable and unobservable factors that proxy for skill. Beyond the standard demographics found in scores of studies on wage levels and gaps (Altonji and Blank 1999; Card 1999), we control explicitly for self-selection into the labor force and migration into the region of residence (Blundell, et al. 2006; Dahl 2002; Juhn, et al. 1993). With the secular rise of employment among women and concurrent decline among men, it is important to control for unobserved factors related to these trends, and the possibility that these processes differ between Appalachia and the rest of the nation. Likewise, even conditional on observables, selection into and out of the Appalachian region may not be exogenous to wages, and thus our model controls for endogenous migration.

In addition to the conditional mean, we also estimate the determinants of wages across the distribution. Black and Sanders (2004) suggests that earnings inequality in Appalachia in the 1980s and 1990s was lower and rose more slowly than the rest of the United States. This may be due to slower wage growth at the higher ends of the earnings distribution, or it may be due to faster wage growth at the lower ends of the earnings distribution. By specifically examining the determinants of wages throughout the distribution we more clearly understand the implications 
of the observed changes. We estimate quantile wage equations across the region-gender wage distributions, again controlling for nonrandom selection into the labor force and into the region of residence using the methods of Buchinsky (1998; 2001). Given the estimated coefficients at the conditional mean and conditional quantiles, we then decompose the regional wage gaps into the shares attributable to differences in demographics and in coefficients (Oaxaca 1973; Machada and Mata 2005). Applications of mean wage decompositions controlling for sample selection bias are scarce (Chandra 2003; Neuman and Oaxaca 2004; Neal 2004), and the quantile approach with selection is even more rare (Albrecht et al. 2008; Blundell, et al. 2006).

The data for our analysis are the 1980-2000 Integrated Public Use Microdata Samples (IPUMS) of the Decennial Census. Because counties are not identified in the IPUMS we employ a weighting method that identifies the share of a public use area (a PUMA for every 100,000 persons) that is defined by the Appalachian region, and weight all regressions by the appropriate share. For historical purposes, our base case compares Appalachia to the rest of the nation, but because it is a relatively rural region, we also consider a number of alternative comparisons such as rural Appalachia to rural non-Appalachia, and urban Appalachia to urban non-Appalachia.

Although we find substantial evidence of skill upgrading in Appalachia, college completion rates still lag behind the rest of the country, and by 2000 the relative wage premium to schooling in Appalachia was lower, contrary to early decades. A consequence is that the majority of the regional wage gap in 1980 for men and women was due to demographic differences whereas by 2000 it was accounted for by differential returns to skill. While much of the difference in mean wages is confirmed by the distribution decomposition, we find that the coefficients gap is more important in explaining the preponderance of low-wage male workers in Appalachia, while both the skills and returns gaps are important for explaining the lack of high wage workers in Appalachia. For women, differences in demographics appear to be important across the distribution. One potential explanation for our findings is that Appalachia suffers from “missing markets," both a paucity of high skilled workers and low returns for those with high skills, that is most pronounced in the urban areas of the region.

\section{Background and Data}

Few regions within the United States have engendered as much attention as Appalachia in discussions of poverty (Caudill 1962; Harrington 1962; Duncan 1999; Eller 2008). In 1964 President Johnson traveled to the small town of Inez, Kentucky to launch the nation's 'War on 
Poverty,' and several Presidential candidates have included 'poverty tours' of Appalachia as part of their campaigns. Appalachia was first designated as a special economic zone in 1965 with passage of the Appalachian Regional Development Act. The Act defined the economic zone of activity and created a federal and state partnership known as the Appalachian Regional Commission (ARC) whose mission is to expand the economic opportunities of the residents by increasing job opportunities, human capital, and transportation. The ARC-designated region traces the Appalachian Mountains from southern New York to northern Mississippi, spanning parts of twelve states and all of West Virginia (see Appendix Figure 1). ${ }^{1}$ As of 2000, 406 counties were included in Appalachia, and over $\$ 13$ billion had been spent by ARC on the region (Glaeser and Gottlieb 2008).

Although much of Appalachia is rural, it does encompass about ten percent of the nation's population and includes several urban centers such as Pittsburgh, PA, Knoxville, TN, and Birmingham, AL. Historically the region was heavily dependent on resource extraction (coal and timber in the central area), manufacturing (especially steel in the north), and agriculture (cotton and tobacco in the south) (Eller 2008). Appalachian poverty has exceeded national poverty rates by 10 to 20 percent, but in the central Appalachian region poverty is nearly double the national rate. Median income in Appalachia is at least $\$ 10,000$ below the national median, differences in median income have widened in recent decades. ${ }^{2}$ While still lagging behind the United States as a whole, the Appalachian region has shown some social and economic convergence toward the rest of the country during the last decade (Black and Sanders 2004; Pollard 2003; Haaga 2004). Even still, perhaps because of the searing portraits of grinding poverty by Caudill (1962) and Harrington (1962), to this day Appalachia is often viewed as 'the other America.'

As recent as 1980 only 67 percent of residents in Appalachia had completed high school or its equivalent, compared to 76 percent outside the region. ${ }^{3}$ By 2000 the fraction of prime age Appalachians with at least high school rose to 86 percent, while it rose more slowly to 88 percent outside the region. Based on the analysis of Lemieux (2006), we would expect this relative education upgrading to narrow regional wage differentials between 1980 and 2000. At the same

\footnotetext{
${ }^{1}$ Inclusion in ARC was based in part on proximity to the Appalachian Mountains, in part on economic distress, and in part on political economy (Eller 2008).

${ }^{2}$ See "Economic Overview" at http://www.arc.gov/index.do?nodeId=26.

${ }^{3}$ Author's calculations based on IPUMS data from 1980 and 2000 Decennial Census as described in the Data Section. These estimates pool men and women, but we conduct our analyses below separately by gender.
} 
time, the gap in college graduation rates across regions actually expanded from 6 to 8 percentage points between 1980 and 2000. The results of Autor, et al. (2008) suggest that this gap in highly skilled workers would point to widening of regional wage differentials. In fact, the average wage gap between workers in Appalachia and the rest of the nation rose from 9 log points in 1980 to 13 log points in 2000, which seems more consistent with Autor, et al. (2008). Both scenarios, however, assume that the standard result of factor-price equalization holds across regions. Recent evidence by Dahl (2002) and Black, et al. (2009) calls this assumption into question as they find persistent differences in schooling returns across states and cities, respectively. How skill returns in Appalachia evolved over time relative to the rest of the nation is not known, and yet is critical to the regional evolution of inequality.

Appalachia is of interest not only because of its historical significance in the nation's fight against poverty, but because its large geographic coverage that spans remote rural areas as well as some mid-size and large cities offers the opportunity to study the role that urban areas play in regional economic development. It has long been true that urban areas have more skilled workers than rural areas. Moretti (2004) shows that the gap in skill between the most and least skilled urban areas has risen since 1980 and this increase in skill dispersion is correlated not only with the level of workers' skill, but also with the size of the area, wealth and industrial structure. Urban areas with large concentrations of hi-tech industries experienced the largest gains in skill over this period. In turn, this growth in the skill gap accounts for some of the overall growth in the income gap between 1980 and 2000. Since the urban areas in Appalachia tend to be smaller, poorer, and contain very little hi-tech industry, decomposing wage changes between urban and rural areas within Appalachia, as well as between urban and rural areas inside and outside of Appalachia will help document the role regional differences in skill and skill accumulation have in accounting for the earnings gap in the U.S.

To address the potential importance of urban areas in the analysis, we include comparisons of rural Appalachia to the rest of rural America, of urban Appalachia to urban nonAppalachia, and for the central Appalachian region (the coal producing states) to the residents in non-Appalachia living in rural areas and metro areas with fewer than one million persons. Indeed, the legislation establishing ARC mandated that resources be directed to the locales with the greatest potential for economic growth, which not surprisingly were the urban centers of the 
region (Eller 2008). Thus, the supplemental analyses on the urban areas of Appalachia are of independent interest.

\section{A. Data}

Our data derive from the Integrated Public Use Micro Samples (IPUMS) of the 1980, 1990 and 2000 Decennial Census. The IPUMS contain variables commonly used in estimation of wage equations and also include geographic identifiers. We begin our data in 1980 because earlier IPUMS data contain no geographic identifier below the state level; thus, it is not possible to estimate individual-level wages separately for the Appalachian region. ${ }^{4}$ We select working and non-working individuals between the ages of 25 and 60, who do not have missing or allocated wages. The age cutoffs are chosen to minimize the presence of full time students and those nearing retirement. Dropping those with allocated earnings avoids attenuation bias in skill returns (Bollinger and Hirsch, 2006). The resulting sample has 7 million men and 8 million women across the three Censuses.

The key advantage of the IPUMS data are the long time series of cross sections and the exceptionally large sample sizes that permit identification of region-by-gender skill returns across the wage distribution. The data are limited because the geographic identifiers that are made publicly available are not perfectly coincident with the Appalachian Region. ${ }^{5}$ The smallest geographic unit reported in the IMPUS is the Public Use Micro Area, or PUMA, containing groupings of 100,000 residents. In most cases the PUMA is fully contained within either Appalachia or non-Appalachia and thus individuals can be assigned as Appalachian residents (or not) simply from the PUMA information. However, a few PUMA's contain counties in both regions, and for these cases we use supplementary information from the Decennial Census Summary Files to determine the proportion of residents in a particular PUMA who live in Appalachia. These proportions are then used to weight individual observations in the summary statistics and regression models to follow. Since the Summary Files contain detailed population counts by age, sex, and race, the weights are constructed to reflect the probability that the particular individual actually lives in Appalachia. This weighting procedure has its roots in weighting for stratified samples and weighting for item non-response (Groves, et al. 2004).

\footnotetext{
${ }^{4}$ The variable "county group" in the 1970 Census is collected solely for the metropolitan sample, which misses most of the Appalachian region.

${ }^{5}$ A lesser concern is the fact that the definition of the Appalachian region has changed slightly over our sample period. In 1980397 counties were included in Appalachia, and by 2000 the number of counties was 406.
} 
Our outcome of interest is the log real hourly wage rate. We construct the real wage as the ratio of annual earnings to the product of weeks worked and hours of work per week, and then deflate the average hourly wage by the personal consumption expenditure deflator with 2000 as the base year. ${ }^{6}$ Key demographic variables available in the Census and pertinent to our analysis include education attainment, potential experience (defined as age minus years of schooling minus 6), race and ethnicity, marital status, living in an urban area (=1 if the Beale rural-urban continuum code is 3 or less), and one-digit industry (for workers).

Table 1 contains summary statistics on key economic and demographic variables for our sample of working and non-working men and women in each of the last three Decennial Censuses broken down by residency in Appalachia. Among men inside Appalachia versus those outside, we see that the log wage gap widened from 0.095 log points in 1980 to 0.126 log points in 1990 and then held steady at 0.123 in 2000. The widening in the 1980s occurred because male wages in Appalachia fell more than those in the rest of the nation, while in the 1990s the wages of men within Appalachia grew slightly more than the wages outside the region. Among women, the wage gap widened from 0.12 log points to 0.17 between 1980 and 1990, and like men, women in both regions experienced wage growth in the 1990s but wages of those inside Appalachia grew faster and narrowed the gap to 0.16 .

There are several other trends of note in Table 1. First, there is a slight decline in employment among men, and a more discernable rise among women. The regional gap in employment rates for men range from 2 to 3 percentage points, and employment fell more rapidly among men in Appalachia between 1980 and 2000. Women in Appalachia, however, had employment rates 7 percentage points lower in 1980 compared to women outside the region, but cut the gap roughly in half in the ensuing two decades. Second, there is evidence of relative education upgrading in Appalachia between 1980 and 2000. Appalachian men are now significantly more likely to matriculate from high school and to complete some college, while Appalachian women showed large gains in some college and advanced degrees. Ceteris paribus,

\footnotetext{
${ }^{6}$ Since we estimate the models separately by year, deflating by the expenditure deflator is not necessary, but it is needed to discuss the summary statistics over time. On the other hand, Card and Krueger (1992) deflate wages by the average wage in the state to account for state-specific differences in cost of living, and Moretti (2008) proposes a city-specific version of the CPI to account for cost-of-living differences across metro and non-metro areas. A priori it is not clear whether one should adjust wages for local cost-of-living differences as the latter may be outcomes affected by the preferences of the community, which in turn are affected by the demographic composition (DuMond et al 1999). As a consequence we chose not to use a local price deflator, though we capture some broad effect of location by controlling for urban residence.
} 
this convergence in education attainment should narrow the gap in wages. Third, the Appalachian region has become more diverse in terms of racial composition. Borjas (2004) shows that the South experienced marked increases in immigrants during the 1990s both from increases in the number of newly-arrived persons as well as internal migration to the South. These new immigrants were much more likely to settle in the Appalachian South than in earlier decades. These immigrants tend to be low skilled and this could possibly exacerbate regional wage differences. Fourth, there is a large secular decline in marriage rates across the board of about 16 percent. Last, in terms of industrial composition of the male workforce, both regions experienced employment declines in manufacturing and transportation, and both experienced growth in retail trade, FIRE, and business and repair services. In most cases, though, the regional differences in industrial composition either held steady or converged.

\section{Wage Determination and Wage Decompositions}

We begin by specifying the typical human capital wage equation:

$$
\ln W_{i j r t}=X_{i j r t} \beta_{j r t}+\varepsilon_{i j r t},
$$

where $\ln W$ is the natural log of the real average hourly wage rate for individual $i$ of gender $j$ residing in region $r$ (Appalachia and Non-Appalachia) during Decennial Census year $t$. The demographics $X$ that serve as observable proxies of skill include indicators for education attainment (high school dropout [omitted], high school, some college, college, post graduate), indicators of potential experience (0-10 [omitted], 10-20, 20-30, 30-40, > 40), interactions of education and experience (Heckman, Lochner, and Todd 2003), race and ethnicity, marital status, and urbanicity. We also present results of models that include industry controls so that we can examine the role that changes in industry composition had on the wages of workers. ${ }^{7}$ Least squares estimation of equation (1) will fail to provide consistent estimates of $\hat{\beta}_{j r t}$ if $E\left[\varepsilon_{i j r t} \mid X_{i j r t}\right] \neq 0$, which we hypothesize can occur for two reasons-nonrandom selection into the labor force and nonrandom selection into the geographic region of residence.

\section{A. Endogenous Selection into Employment and Region}

Wages are observed only for those who are employed. Although concerns about selection on unobservables into work have been more prominent in research on women's wages than

\footnotetext{
${ }^{7}$ There are a few other possible covariates available in the Census that might bear on a worker's productivity, including veteran's status and health status. Both variables have been shown to be important determinants of workers' wages (Berger and Hirsch 1983; Angrist 1990; Haveman et al. 1994), but in general are endogenous to wages and thus we exclude them from our analyses.
} 
men's, the differential decline across regions in labor force participation of men in Table 1, and the differential rise in employment among women, implies that endogenous selection into and out of work is a potential concern not just for women but for men as well (Blundell and MaCurdy 1999; Bound and Burkhauser 1999).

To address labor-market selection we specify a latent variable model of the form

$$
E_{i j r t}^{*}=Z_{i j r t} \gamma_{j r t}+\eta_{i j r t},
$$

where $E_{i j r t}^{*}$ is the latent propensity to work, $Z_{i j r t}$ are observed characteristics, and $\eta_{i j r t}$ are unobserved components. Since we only observe whether the person is employed or not, i.e. $E_{i j r t}=1$ or 0 , then being employed implicitly occurs when $E_{i j r t}^{*}>0$. A key issue in selection models is how the selection effects are identified separately from the observed factors affecting wages. We rely on exclusion restrictions such that $Z$ includes the variables in $X$ along with additional person and state specific covariates. The person-specific exclusion restrictions available in the Census to identify selection into work but not wages follows from the canonical model of labor supply (Blundell and MaCurdy 1999), including nonlabor income, the total number of children, and the number of kids under age 5. The state-specific variables used to identify the employment decision include those that affect the generosity of welfare and disability such as the combined maximum monthly benefit guarantee for the Supplemental Security Income plus food stamps and the combined maximum monthly benefit for Aid to Families with Dependent Children and food stamps; institutional constraints including the state minimum wage; business cycle conditions such as the state unemployment rate; and state political preferences as represented by the party affiliation of the state's governor. We also include the family-size specific subsidy rate for the federal Earned Income Tax Credit (Hotz and Scholz 2003). The state-specific variables are obtained from the University of Kentucky Center for Poverty Research (http://www.ukcpr.org/AvailableData.aspx ).

In addition to employment selection, the structure of wages can also be influenced by potential endogenous migration decisions (Dahl 2002). The standard model of migration predicts that workers will sort into the location offering the highest wages given the level of skills, and if these migration decisions are influenced by factors unobserved to the researcher, then ignoring nonrandom migration will lead to biased estimates of equation (1). 
The Decennial Census contains information on the place of residence as of five years prior to the Census. ${ }^{8}$ We define a 'stayer' in Appalachia if one resided in the region in both periods, a 'mover-in' to Appalachia as someone who currently resides in Appalachia but did not five years prior, and a 'mover-out' of Appalachia as someone who lived in Appalachia five years ago but no longer lives in the region. Stayers and movers in non-Appalachia are defined similarly. Appendix Table 1 demonstrates that the fraction of persons moving into Appalachia exceeds that of movers out, the result of which is that the five-year stayer rate in Appalachia is declining over time because in-migration is altering the composition of the region. Appendix Table 2 shows that among both men and women, those who move out of Appalachia are two to three times more likely to have completed college or received post-graduate training than those who stay in the region. As for those who move into Appalachia, they too are more educated than stayers, but have less schooling than those who move out. On net, there is some evidence of a brain drain in Appalachia due to migration.

To address possible endogenous migration we again specify a latent variable model

$$
S_{i j r t}^{*}=D_{i j r t} \gamma_{j r t}+\xi_{i j r t}
$$

where $S_{i j r t}^{*}$ is the unobserved propensity to stay in your current location, $D_{i j r t}$ are observable characteristics and $\xi_{i j t}$ are unobservable characteristics. Since we only observe whether the person has stayed or moved, i.e. $S_{i j r t}=1$ or 0 , then staying implicitly occurs when $S_{i j r t}^{*}>0$. In this case $D$ includes the variables in $Z$, i.e. those variables in the labor force selection equation, along with the identifying variable of whether or not the person was born in a state within Appalachia. Dahl (2002) used the birth state as his identifying restriction under the assumption that state of birth affects latent geographic preferences to live, but not wages conditional on making the migration decision. Card and Krueger (1992) include state of birth as a direct determinant of weekly earnings, but the argument in Dahl (2002) is that in a two-stage optimization problem state of birth affects the first stage of whether to move or not, but conditional on controlling for the migration choice, state of birth does not affect wages except indirectly through the migration decision. We follow a similar identification scheme as Dahl, but instead of selection into one of 50 states we only estimate selection into one of two regions and

\footnotetext{
${ }^{8}$ In 1980 the Census only asked the migration questions for one-half of the sample. Because they were randomly assigned, the data are representative of each region as a whole.
} 
rely on the cross-section heterogeneity in state of birth to identify the model. Appendix Table 2 shows that 90 percent of men and women in 1980 and 1990 currently residing in Appalachia were born in the region, and while it fell to about 86 percent by 2000, the high concentration of native-born in the region suggests the variable is a strong predictor of staying.

Based on equations (2) and (3) we specify the conditional mean of the error term in equation (1) as

$$
E\left[\varepsilon_{i j r t} \mid X_{i j r t}\right]=\sum_{k=1}^{K} \delta_{k j r t} \lambda_{i j r t}^{(k)}\left(\gamma_{j r t}\right)+\sum_{k=1}^{K} \varphi_{k j r t} \lambda_{i j r t}^{(k)}\left(\pi_{j r t}\right),
$$

which is a series estimator that admits possible non-linearity in labor force selection (the first term) and migration decisions (the second term) via higher order terms of $\lambda$ (Lee 1984). To operationalize the model, in the first step we estimate the decisions to work and to migrate, which yields the estimated parameters, $\hat{\gamma}_{j r t}, \hat{\pi}_{j r t}$. The second step of estimation then involves constructing the terms in equation (4) with the estimated first-stage parameters and appending them to equation (1)

$$
l n W_{i j r t}=X_{i j r t} \beta_{j r t}+\sum_{k=1}^{K} \delta_{k j r t} \lambda_{i j r t}^{(k)}\left(\hat{\gamma}_{j r t}\right)+\sum_{k=1}^{K} \varphi_{k j r t} \lambda_{i j r t}^{(k)}\left(\hat{\pi}_{j r t}\right)+u_{i j r t} .
$$

We estimate equation (5) via OLS separately for each region, gender, and year only for those individuals who are working stayers in each region. As a practical matter, we set $K=1$ in our base case and estimate the work and migration equations (2) and (3) via probit maximum likelihood, which yields the usual two-step Heckman correction (Heckman 1979); however, we also present results when we set $K=2$ and for the case with a linear probability selection model (Olsen 1980). ${ }^{9}$

\section{B. Mean Wage Decompositions}

To compare differences in average wages between two populations (for example, Appalachia and non-Appalachia in 2000), we employ a modified version of the Oaxaca (1973) and Blinder (1973) method that decomposes wage gaps into differences in the coefficients and differences in the observable characteristics that is robust to non-random selection. Typically one decomposes the mean of actual wages of workers, and it is possible to do the same here but include the average differences in the selection correction terms (Neuman and Oaxaca 2004). ${ }^{10}$

\footnotetext{
${ }^{9}$ We explored estimating the selection terms with a semi-parametric model of Ichimura (1993), but the very large sample sizes coupled with large number of covariates made the problem prohibitive and it failed to converge. In addition, we assume independence between the selection terms, the violation of which is typically thought to be second order (Wooldridge 2001).

${ }^{10}$ In an earlier version of this paper we presented the decomposition of selectivity adjusted wages of working stayers in each region, but the current approach is more instructive on the whole structure of wages. That said, it is possible
} 
However, in our case we are interested in the wage distribution facing the entire population including non-workers as well as workers regardless of realized migration decision. Thus we decompose the offer wage distribution rather than the realized wage distribution.

We predict offer wages by using the observed demographics of the whole population of men and women in each region and year along with the selectivity-corrected coefficients, $\hat{\beta}_{j r t}$. Specifically, if we define $\ln \widehat{W}_{i j t}^{A}=X_{i j t}^{A} \hat{\beta}_{j t}^{A}$ as the predicted offer wages (of workers and nonworkers, and movers and stayers) of gender $j$ in time period $t$ for the Appalachian region ( $A$ ), and $\ln \widehat{W}_{i j t}^{N A}=X_{i j t}^{N A} \hat{\beta}_{j t}^{N A}$ as the corresponding predicted offer wages outside Appalachia $(N A)$, then we can decompose the offer wages at the means by using either the Appalachian coefficients or the non-Appalachian coefficients as the reference price vector. The average predicted nonAppalachian-Appalachian wage gap based on non-Appalachian coefficients is

$$
\ln \overline{\widehat{W}}_{j t}^{N A}-\ln \overline{\widehat{W}}_{j t}^{A}=\left(\bar{X}_{j t}^{N A}-\bar{X}_{j t}^{A}\right) \hat{\beta}_{j t}^{N A}+\bar{X}_{j t}^{A}\left(\hat{\beta}_{j t}^{N A}-\hat{\beta}_{j t}^{A}\right),
$$

where the first term on the right hand side represents the average offer wage gap accruing to demographic differences across regions, and the second term reflects differences in coefficients. Because the decomposition in equation (6) can be sensitive to the reference set of coefficients we also present estimates of (6) using the Appalachian coefficients as the reference group.

\section{Quantile Wage Decompositions}

The Oaxaca-Blinder decomposition focuses upon differences in average offer wages; however, as noted in the voluminous inequality literature there have been important changes throughout the earnings distribution. We thus extend our previous analysis to decompose changes in the entire wage distribution using quantile regression techniques and building on the methodology of Machado and Mata (2005), hereafter denoted as MM. The value of examining the wage distribution is that if by estimating equation (5) we observe that the rate of return to education has increased in Appalachia on average, that increase at the mean may reflect that it shifted up among all persons, or it may be that the lowest rates of return have improved dramatically, but the highest rates have not (or vice versa). Understanding these distinctions has important implications for the role of increasing skill levels versus rising returns to skill across the distribution. 
The MM procedure uses estimated quantiles of the conditional wage distribution to conduct a series of counterfactual decompositions of the distribution by simulating the marginal wage distributions under alternative scenarios. This approach differs from DiNardo, et al. (1996) who estimate wage models with nonparametric kernel densities and are not able to separately identify the contributions of variables compared to coefficients. ${ }^{11}$ Autor, Katz and Kearney (2005) extend the MM approach for wage distributions by separately identifying the contribution of ‘within-group' inequality from ‘between-group' inequality and observed versus unobserved skill in the spirit of Juhn, Murphy, and Pierce (1993). Our approach extends the MM method in a different fashion from Autor, et al. (2005) by explicitly admitting nonrandom sample selection bias into the quantile model. ${ }^{12}$ As shown in Datta Gupta, et al. (1998) there is a close relationship between the Oaxaca approach with selection and the Juhn, et al. method.

To implement the MM procedure we first estimate a variant of the selection-corrected conditional quantile proposed by Buchinsky (1998)

$$
\ln W_{i j r t}=X_{i j r t} \beta_{j r t}^{\theta}+\sum_{k=1}^{K} \delta_{k j r t}^{\theta} \lambda_{i j r t}^{(k)}\left(\hat{\gamma}_{j r t}\right)+\sum_{k=1}^{K} \varphi_{k j r t}^{\theta} \lambda_{i j r t}^{(k)}\left(\hat{\pi}_{j r t}\right)+u_{i j r t}
$$

for each quantile $\theta$ on the sample of workers and stayers that yields the vector of gender, region, and year-specific coefficients $\left(\hat{\beta}_{j r t}^{\theta}, \hat{\delta}_{k j r t}^{\theta}, \hat{\varphi}_{k j r t}^{\theta}\right)$. In order to capture wide heterogeneity in the distribution of wages we estimate equation (7) for 99 quantiles ranging from 0.01 to 0.99 . Using the same identification strategy as in the case of the conditional mean, we estimate the first stages in equations (2) and (3) as probit models, and set $K=1$ under the assumption that the nonlinearity of inverse Mills ratio coupled with the exclusion restrictions should provide

\footnotetext{
${ }^{11}$ Recently Firpo et al. (2007) proposed a new method of estimating unconditional quantiles that permits decompositions into differences in coefficients and differences in regressors similar to MM. The advantage of their approach over MM is that they are also able to identify the contributions of specific regressors to the wage gap, while the MM approach only permits a decomposition of the whole vector of regressors. This variable by variable approach has always been possible with the linear Oaxaca-Blinder decomposition method, but as first noted by Jones (1983), the results are sensitive to the choice of reference group if any of the regressors are dummy variables. Although the Firpo et al. method is an elegant extension of the literature, the set of regressors in our model are dummy variables and our interest is primarily on the full index of skills. More importantly, quantile methods adjusted for sample selection have been developed previously by Buchinsky $(1998 ; 2001)$ but as of yet similar results have not been established for unconditional quantiles, though Blundell, et al. (2006) recently proposed a bounding procedure for quantiles with selection.

${ }^{12}$ Independently Albrecht, et al. (2008) proposed a similar extension to the MM method and applied it to gender wage gaps in the Netherlands.
} 
sufficient flexibility in the selection process to separately identify $\hat{\beta}_{j r t}^{\theta}$ from $\left(\hat{\delta}_{k j r t}^{\theta}, \hat{\varphi}_{k j r t}^{\theta}\right)$ in the quantile wage equation (7). ${ }^{13}$

With the estimated conditional quantile coefficients we then construct counterfactual distributions by simulating out the marginal “offer” wage distribution using the demographics from the whole population of workers and non-workers and movers and stayers in each gender, region, and year along with the estimated coefficients on the observed demographics, $\hat{\beta}_{j r t}^{\theta}$. We decompose the predicted offer distributions into differences in skills and differences in coefficients as before, but now for 99 quantile points rather than just the mean. For example, suppose we take the coefficients and demographics from the non-Appalachian region as the reference group. We can construct a counterfactual distribution using demographic characteristics drawn from the Appalachian region by first drawing observations randomly (with replacement) from the Appalachian data and randomly assigning a quantile, $\theta, \theta \in[0.01,0.99]$ to each drawn observation. Then we generate a predicted wage using the non-Appalachian quantile coefficients indicated by that observation's $\theta$ and the demographic variables $(X)$ of that observation. This generates a simulated distribution of wages as if individuals in non-Appalachia had the same distribution of $X$ 's as the Appalachian region.

The procedure is comparable to the term $X_{i j t}^{A} \hat{\beta}_{j t}^{N A}$ in a standard Oaxaca-Blinder decomposition. We can then compare differences in the non-Appalachian offer wage distribution to this counter-factual distribution: differences are solely due to differences in demographics and are comparable to the term $\left(X^{N A}-X^{A}\right) \hat{\beta}^{N A}$ in the Oaxaca-Blinder decomposition found in equation (6) with non-Appalachia as the reference price vector. We can also compare differences in the counterfactual distribution and the predicted offer wage distribution in Appalachia: differences are solely due to coefficients on the demographics and are comparable to the term $X^{A}\left(\hat{\beta}^{N A}-\hat{\beta}^{A}\right)$ in the Oaxaca-Blinder decomposition.

\section{Results}

The first stage estimates for the probability of employment in equation (2) and for the probability of staying in equation (3) are presented in Appendix Tables 4 and 5, while the final wage regression estimates are presented in Appendix Table 3. In general the exclusion

\footnotetext{
${ }^{13}$ Buchinsky (1998) used a probit as well as a semi-nonparametric estimator in the first stage, but then a powered-up version of the inverse Mills Ratio as we do in the second stage. With two separate selection terms we opted for the parametric first stage in order to enhance transparency and computational feasibility with our very large datasets.
} 
restrictions are highly predictive of work and staying in the region. For example, higher nonlabor income, more children under age 5, and a higher state unemployment rate are each associated with a lower probability of employment, while a more generous EITC increases the odds of employment. Being born in an Appalachian state is highly predictive of currently living in Appalachia and not living outside the region. There is strong evidence of nonrandom selection into the region of residence for all years for both men and women, and the same is true for nonrandom selection into work, except for women in 1980 where it appears that controlling for selection on observables was sufficient for wages. We note in passing that failure to control for nonrandom selection into work and region tends to lead to an upward bias in the returns to schooling and experience among men, but it has little impact on the trends in the wage decompositions discussed below.

As one would expect, both education and potential experience are important to the determination of wages for both men and women in each region, but large coefficients on the interactions of education and experience also clearly reject the null hypothesis of separability between education and experience assumed in the canonical Mincer equation (Heckman, Lochner, and Todd 2003). Because of the importance of these interactions, this implies that the return to schooling is highly nonlinear. Thus, to assist in interpretation, in Figures 1 and 2 we plot the percentage wage gain of schooling relative to a high school dropout for a worker with 10-20 years of potential experience.

Figure 1 reveals that there was large increase in the relative return to some college or better in the 1980s for men, both within and outside Appalachia. This result has been well documented in the literature for the nation as a whole, and the estimates here indicate that the trend was also true for the economically depressed region of Appalachia. Indeed, the relative return to college and post-graduate degrees for a man with 10-20 years experience was actually higher in Appalachia in 1980 and 1990 compared to non-Appalachia. This gradient is consistent with a higher return offered to workers whose skills are in relatively short supply, which may have characterized the situation in Appalachia since Table 1 shows that there are fewer individuals with advanced degrees in Appalachia than in other parts of the country. The 1990s were a different story for men in Appalachia. Although the relative return to college and advanced degrees continued to rise in both regions of the country, they rose more quickly outside Appalachia, and actually surpassed the Appalachian returns by 2000. In fact, the proportionate 
wage gain for high school and some college in Appalachia actually declined after 1990, so that the wage gains at all education levels for this experience cohort of men fell compared to the rest of the nation. This divergence in schooling returns will exacerbate within-Appalachian inequality consistent with the polarization story of Autor, et al. (2008), but will also increase betweenregion inequality. These trends were not specific to the cohort of men with 10-20 years potential experience as they likewise hold for workers with 30-40 years experience.

Similar to the male experience, in Figure 2 there is strong evidence of rising relative returns to skill in the 1980s among women, but this was especially strong outside of Appalachia. Indeed, the wage gain for a college graduate relative to a dropout was a fairly constant 72-74 percent from 1980-2000, whereas it rose from 61 percent to 88 percent in the same period outside of Appalachia. Also like men, there was a reversal between 1980 and 2000 in that the wage gain for women in Appalachia in 1980 exceeded non-Appalachia at nearly every education level, but was lower at every level by 2000. Even though there was education upgrading in Appalachia in recent decades, especially at the high school and some college levels, the relative wage gains fell behind the rest of the nation.

The other coefficients in Appendix Table 3 show that most racial groups earn lower hourly wages than white non-Hispanics, but these gaps appear to be larger outside of Appalachia, at least after 1980. In addition, the premium associated with residing in an urban area is at least double outside of Appalachia for both men and women, suggesting that there are important differences in wage opportunities in urban areas across regions, a point that we return to below. Being married paid off more for men in Appalachia than those outside of the region in both 1980 and 1990; however, the relative difference in the marriage premium fell from 39 percent in 1980 to a negative 1 percent in 2000 because of a large secular rise in the returns to marriage in the 1990s among men outside of Appalachia. Both the rates of marriage and the returns to marriage for Appalachian men have fallen over the past decade. Although Wilson's (1987) thesis on the decline of "marriageable men" was initially applied to low-skilled urban African Americans, the results here are suggestive that such a phenomenon may be in evidence in Appalachia as well.

\section{A. Decomposing Changes in Average Wages}

In Table 2 we report the selection-corrected wage offer decompositions at the means for each year from equation (6). The table shows the mean difference in offered wages (not the actual wage as in the summary statistics in Table 1), the portion of the gap due to differences in 
observed demographics, and the portion due to differences in coefficients. For both men and women, we report the gap first based on non-Appalachian coefficients as the reference group and second based on Appalachian coefficients, along with analytic standard errors (Jann 2005). ${ }^{14}$

The mean offered wage gap for men rose about 28 percent between 1980 and 2000, but that was substantially lower than the 54 percent increase between 1980 and 1990 (the actual gap in Table 1 increased 33 percent between 1980 and 1990, the difference between the offer wage gap and actual wage gap arising from selection effects). Based on the non-Appalachian coefficients, in 1980 three-fifths of the 0.101 wage gap was due to demographic shortfalls among Appalachian men, and the remainder was due to regional differences in coefficients. By 2000, however, the portion due to demographic differences fell by 20 percentage points and the portion due to coefficients rose a comparable amount. An even more dramatic shift from demographic gaps to coefficient gaps from 1980 to 2000 emerges when using Appalachian coefficients as the reference prices. The differences are all statistically different from zero. Although there is evidence that skill upgrading in Appalachia during the 1980s and 90s played an important role in equalizing inter-regional wages, the widening of the average wage gaps are a result of the divergence in skill returns.

The offered wage gap between non-Appalachian women and Appalachian women is both smaller than that of men, and widened by less in the 1980s (just the opposite of the actual wage gap in Table 1, again highlighting the importance of controlling for nonrandom selection). However, like men, the gap narrowed somewhat in the 1990s. And while qualitatively similar to men, the pattern over the past two decades toward less of the gap explained by demographics and more of the gap explained by coefficients is much more muted for women. In each year, differences in demographics account for a majority of the wage gap among women.

\section{B. Decomposing the Distribution of Wages}

Because of the myriad of estimated coefficients from the quantile models in equation (7) -99 quantiles each with 18 coefficients by year, region, and gender (over 21,000 coefficients

\footnotetext{
${ }^{14}$ The formula's for the analytic standard errors are based on a Taylor series approximation under the assumption of independence across samples. Because of overlap of samples due to our weighting procedure, independence is violated, but the overlap is trivial and is ignored in the standard errors. The variance formulas for each term in equation (6) are given as $V\left(\left[\bar{X}_{j t}^{N A}-\bar{X}_{j t}^{A}\right]^{\prime} \hat{\beta}_{j t}^{N A}\right)=\left(\bar{X}_{j t}^{N A}-\bar{X}_{j t}^{A}\right)^{\prime} V\left(\hat{\beta}_{j t}^{N A}\right)\left(\bar{X}_{j t}^{N A}-\bar{X}_{j t}^{A}\right)+\hat{\beta}_{j t}^{N A^{\prime}}\left[V\left(\bar{X}_{j t}^{N A}\right)+V\left(\bar{X}_{j t}^{A}\right)\right] \hat{\beta}_{j t}^{N A}+$ $\operatorname{tr}($.$) and V\left(\bar{X}_{j t}^{A \prime}\left[\hat{\beta}_{j t}^{N A}-\hat{\beta}_{j t}^{A}\right]\right)=\bar{X}_{j t}^{A^{\prime}}\left[V\left(\hat{\beta}_{j t}^{N A}\right)+V\left(\hat{\beta}_{j t}^{A}\right)\right] \bar{X}_{j t}^{A}+\left(\hat{\beta}_{j t}^{N A}-\hat{\beta}_{j t}^{A}\right)^{\prime} V\left(\bar{X}_{j t}^{A}\right)\left(\hat{\beta}_{j t}^{N A}-\hat{\beta}_{j t}^{A}\right)+\operatorname{tr}($.$) .$
} 
in total)—we instead follow Machado and Mata and present our quantile decompositions graphically.

Figure 3 presents the Machada-Mata decomposition for men using non-Appalachia as the reference group. The first column presents the differences in the offered log-wage distributions (for workers and non-workers, movers and stayers) between the non-Appalachian and Appalachian regions from the quantile models - like the first column of Table 2 labeled “Difference in Offered Wage.” That is, the estimated coefficients from quantile equation (7) are used in conjunction with the demographics (without the selection terms) for workers and nonworkers, movers and stayers, to construct a predicted wage distribution, and the first column in Figure 3 is the difference in predicted densities. The second column compares the counterfactual distribution constructed using Appalachian $X$ variables and non-Appalachian coefficients ( $\beta^{\prime} s$ ) to the predicted non-Appalachian offered wage distribution - like the second column of Table 2 labeled “Demographics.” The third column compares the counterfactual distribution and the predicted Appalachian wage distribution - like the fourth column of Table 2 labeled "Coefficients.” The difference between the results in Figure 3 and Table 2 are that we can observe which part of the wage distribution is driving the average difference.

The first panel of Figure 3 (first row, first column) displays the difference in the offer wage distributions between non-Appalachia and Appalachia in 1980. The negative values represent places where there is higher density for Appalachia than for non-Appalachia, while the positive values represent areas where there is higher density for non-Appalachia than for Appalachia. Hence, the first panel demonstrates that the distribution of wages for Appalachia is shifted to the left (or lower) of the distribution for non-Appalachia in 1980. The symmetry of the graph indicates that the Appalachian distribution is shifted down relatively uniformly along the wage (x) axis. Thus, the average difference in Table 2 is not being driven only by a lack of high earners in Appalachia or only by a lack of low earners in non-Appalachia.

The second panel (first row, second column) displays the comparison of the counterfactual distribution to the predicted non-Appalachian distribution for 1980. This graph displays the portion of the distributional difference in the first panel which is due to different demographics of Appalachian workers. We first note that the magnitude of the differences is smaller in this graph as compared to the differences in the first panel. Roughly we can say that at least half of the differences in the distribution are attributable to demographic differences. The 
symmetry suggests that the $X^{\prime}$ s for Appalachia are shifted lower relatively uniformly through the distribution.

The third panel (row one column three) of Figure 3 represents the gaps due to coefficients as reflected by the difference in the counterfactual non-Appalachian distribution from the predicted Appalachian distribution. It appears that slightly less than half of the distributional difference is explained by the returns to demographics. This indicates that returns are, in general, higher outside of Appalachia. However, because the distribution is given by the $X$ 's times the returns, Figure 3 shows that the higher $X$ 's in non-Appalachia are associated with higher returns, which may reflect investment in high return characteristics outside of Appalachia (this is confirmed in Appendix Figure 2 that shows the wage gain from completing high school and beyond with 10-20 years of potential experience across the 99 quantiles is higher outside Appalachia at higher wages).

As we move down the three rows we see that the magnitudes in the first column increase between 1980 and 1990 and then falls again between 1990 and 2000. This is consistent with the rise in the average wage gap between 1980 and 1990 in Table 2 and with the constant wage gap between 1990 and 2000. Most importantly, the first column remains symmetric: the distribution

for Appalachian men is shifted down relatively uniformly such that the Appalachian wage gap is constant throughout the wage distribution.

The differences over time in the second and third column of Figure 3 are more striking. By 2000, the magnitude of the differences in the second column (the demographics gap) is attenuated, and like Table 2, we see that demographic differences are less important in explaining the overall wage gap by 2000 . With the demographics gap declining, we see the coefficients gap rising consistently. In results not tabulated, when we ignore nonrandom selection even more weight is placed on the coefficients gap, suggesting an increasing role played by selection into work and region in Figure 3. A similar story emerges in Appendix Figure 3 based on Appalachian coefficients and, if anything, the declining role of demographic differences and rising role of coefficient differences is amplified when Appalachian coefficients are used as the base.

Although there is evidence of convergence in skills between men in Appalachia and nonAppalachia, this convergence is most evident at low wages and there still remains a shortage in Appalachia at the right tail of the distribution. The coefficients gap is exacerbated between 1980 
and 1990, especially at mean log wages and higher, though it is tempered somewhat by 2000. As highlighted in Appendix Figure 2, it appears that the rise in overall differences between 1980 and 1990 was driven by a rise in the schooling returns gap, in particular at the high end. The slight closing of the gap between 1990 and 2000 appears to be driven by a decline in the returns gap. Thus we see that while much of the average difference story in Table 2 is confirmed by the distribution decomposition we learn that the coefficients gap is more important in explaining the preponderance of low wage male workers in Appalachia, while both the demographics and coefficients gaps are important for explaining the lack of high wage workers in Appalachia. In short, Appalachia seems to suffer from a problem of "missing markets” for male workers - the double jeopardy of a lack of high skilled workers coupled with lower returns on those skills.

Figure 4 presents comparable graphs for women (Appendix Figure 4 is based on Appalachian coefficients). As with men, the first column demonstrates that the offer wage distribution for women in Appalachia was lower than the distribution for women outside of Appalachia. Moreover, the difference is symmetric and thus represents a relatively uniform shifting down of the overall wage distribution in Appalachia compared to the rest of the country. In contrast to men, the density difference is less disbursed and generally falls between 1990 and 2000. Table 1 showed that the actual mean wage gap narrowed between 1990 and 2000, and the mean offered gap in Table 2 fell even more, which reflects differential movements in and out of the labor force and region. Figure 4 suggests that the narrowing in the 1990s occurred throughout most of female wage distribution, with the possible exception of very high wages.

The second column of Figure 4 represents the portion of the overall differences due to the demographics gap. The graph is roughly symmetric, similar to men, but the magnitude falls only slightly between 1980 and 2000. Thus, some of the decline in differences between 1980 and 2000 for women is driven by decreasing differences in demographics. The demographics gap appears to be at least half or more of the overall gap in each Census year. Thus, unlike the men, differences in demographics are more important across the entire wage distribution: the preponderance of low wage female workers in Appalachia is explained in part by a lack of skills and the lack of high wage workers in Appalachia is also be explained by a lack of skills.

The third column represents the role of coefficient differences. The odd shape suggests that the coefficient difference is concentrated at the median of the wage distribution. NonAppalachia appears to have a wider distribution of returns, while for Appalachia, the coefficients 
are concentrated near the median. This indicates a lack of high and low returns in the wage distribution. There may be high characteristic women who are receiving lower returns for those characteristics than their non-Appalachian counterparts receive, while there may be low characteristic women who are receiving higher returns for their characteristics than their nonAppalachian counterparts. We also note that by 2000, the differences between Appalachia and non-Appalachia are muted and there is less of a clear distributional story. It appears that the coefficients are no longer driving the differences, while the $X$ 's appear to drive the differences. The muddled coefficient story for women is explained by the fact that labor force selection and migration play a much more important role for women than for men; indeed, in models that ignore selection we find that the role of coefficient gaps explains roughly half the total wage gap in each period. Thus, the wage distribution story for women is similar to men in trends, and like men, there is a widening gap in skill returns at high wage, but selection plays a much bigger role for women in the lower part of the wage distribution.

\section{Sensitivity Analyses}

We considered a number of robustness checks to our results, and because the analysis underlying the trends in average wage gaps largely carries over to the distributional wage gaps, we focus on how the mean decompositions change in response to alternative specifications. In addition, in order to economize on space we report results based only on the Non-Appalachian coefficients, and note in passing that as in the base case of Table 2, the trends among men towards skill upgrading are more pronounced using the Appalachian coefficients.

\section{C.1. Industrial Composition}

As highlighted in the summary statistics in Table 1, the employment trends affecting many one-digit industries were similar across regions, but there were some differences. To account for possible shifting industrial composition we re-estimated our wage models including indicators for industry (but excluded industry from both selection equations) and report the results in the top panel of Table 3. When industry controls are included, the schooling premium for men increases across the board, while it declines for women. In terms of the Oaxaca-Blinder wage decompositions, the percent attributable to demographics falls in 1980 relative to the base case in Table 2, but the trend to more of the gap being explained by differences in coefficients is robust, and indeed strengthened with the inclusion of industry, especially for women. 


\section{C.2. Modeling Selection}

A second robustness check was to relax the normal distribution assumption in the first stage employment and migration models in two ways, one by assuming a uniform distribution and estimating the first stage with a linear probability model and second by relaxing the linearity assumption in the Heckman correction (Olsen 1980; Lee 1984). In the former case, in lieu of the inverse Mills ratio, Olsen (1980) shows that the conditional mean of the error term under least squares is modeled as $(\hat{P}-1)$, where $\widehat{P}$ is the fitted value of the linear probability model. The selection corrections in this case make transparent that identification requires exclusion restrictions as we have in our models described above. In the latter case, Lee (1984) uses Edgeworth expansions to show that linearity in the control function under normality can be relaxed by taking higher order powers as we discuss in equation (4). In this case we set $K=2$. The bottom two panels of Table 3 for each of men and women suggest that the baseline story holds up with the linear probability and quadratic selection terms; namely, that among men there was a shift toward skill return differences in accounting for mean wage gaps, but that the gaps were roughly stable among women and explained by mean differences in demographics.

\section{C.3. Subregions and the Role of Urban Areas}

The wage equation estimates showed that there were significant wage advantages to living in an urban area outside Appalachia as compared to inside Appalachia. In addition, there is a widespread perception that references to 'the other America' are directed at the rural areas of Appalachia, not urban centers such as Pittsburgh and Birmingham. As a consequence in this robustness check we examine the role of urban areas in our wage decompositions for five different subregions: (a) comparing rural non-Appalachia to rural Appalachia; (b) comparing urban non-Appalachia to urban Appalachia; (c) by dropping residents living in urban areas with more than 1,000,000 people; (d) by comparing non-Appalachia to the residents of PUMAs contained in the seven central Appalachian states of Kentucky, Maryland, North Carolina, Ohio, Tennessee, Virginia, and West Virginia; and (e) by comparing non-Appalachian residents residing in urban areas under 1,000,000 to the residents of PUMAs contained in the central Appalachian states. The rural-to-rural and urban-to-urban comparisons presumably removes some of the unobserved heterogeneity across areas and thus may make a more plausible “treatment group-comparison group” evaluation. Likewise, because Appalachia does not contain any of the very large urban areas such as New York, Los Angeles, or Houston, then our base 
results in Table 2 may be unduly influenced by those areas and thus (c) should remove some of that influence. Finally, the Central Appalachian states are more similar in terms of geography and demographics compared to the Deep South and northern sections in New York and Pennsylvania, and are often most frequently perceived of being “the” Appalachian region.

In Table 4 we record the actual average wage gaps for each of the five subregions as well as the overall gap from Table 2 (labeled base case). Most striking is that for men the average wage gap between rural Appalachia and the rest of rural America is zero in both 1980 and 1990, and widens to just under 3 log points in 2000. This suggests that the level of and trend toward a widening wage gap observed over the past two decades was driven by urban areas. The same holds for women in Appalachia as well. When we omit urban areas greater than 1,000,000, the wage gaps fall by 5-10 log points depending on year and whether we examine men or women, suggesting that the actual wage gaps are heavily influenced by large urban areas. As expected the wage gaps widen when we restrict Appalachia to the central states, but when we also drop large urban areas outside Appalachia the wage gaps fall by upwards of 60 percent.

Recall, however, that our decompositions focus on offered wages across the population of workers and non-workers, and thus in Table 5 we record the Oaxaca-Blinder mean offer wage decompositions for the five subregions. We estimated the selection equations (2) and (3) and wage equations (5) and (6) separately for each subgroup, but one limitation in the migration selection equation is that we lack identifying information on whether or not the person was born in an urban or rural location, and thus continue to rely on whether the person was born in an Appalachian state as the exclusion restriction.

In the top panel of Table 5 we see that for both men and women the offered wage gaps between rural Appalachia and the rest of rural America are actually negative, meaning that on average offer wages are higher in rural Appalachia. For men, much like the actual gap, the offer wage gap is near zero. Contrary to the base case, the differences in rural areas across all years for both men and women are wholly accounted for by differences in inter-regional coefficients and not demographics. Comparing urban Appalachia to the rest of urban America in the second panel, we also see that in any given year for both men and women demographic differences explain less of the gap compared differences in coefficients, but this differential widened over time. This suggests that the base case results in Table 2 were driven largely by the increasing importance of urban areas over time offering higher wage returns to skills. Indeed, the remaining 
three panels in Table 4 suggest that it is not that the residents of Central Appalachia are somehow different from other Appalachians, nor that urban areas per se were important to widening interregional wage gaps, rather that it is large urban areas with more than a million people driving much of the Appalachian-non-Appalachia wage gaps in recent decades. Appalachia lacks these large urban areas, and the corresponding growth in wages that such cities enjoyed in recent decades.

\section{Conclusion}

Our results indicate that men and women in Appalachia came 'down from the mountain' in the 1980s and 1990s and significantly upgraded their human capital in terms of education attainment compared to men and women in the rest of the nation. This relative skill upgrading prevented the wages of Appalachians from falling further behind those outside the region during the period of widening inequality overall. As a consequence, the wage distribution for men in Appalachia compared to non-Appalachia is less due to demographic shortfalls than to differences in returns to important skills such as education and experience, the latter of which appears to be driven in large part to the relative decline in returns to schooling in Appalachia over the past two decades. At the same time, however, for men we find that skill shortages remain more pronounced at the high end of the wage distribution, which is borne out in the summary statistics in Table 1 that show that college completion and advanced degrees in Appalachia are about onehalf the rate of attainment in the rest of the country.

Appalachia seems to suffer from "missing markets"-the double jeopardy of a lack of high skilled workers coupled with lower returns on those skills. Perhaps surprisingly, this is most pronounced in the urban areas of Appalachia and not the rural areas as commonly perceived. Indeed, the wage gap between rural Appalachia and the rest of rural America is virtually nonexistent - the wage gap is driven by weakness in the urban areas. As lucidly described by Glaeser and Gottlieb (2008) the policy response to such missing markets in urban Appalachia is not clear ex ante. If there are human capital externalities and/or agglomeration economies that have yet to be exploited in Appalachia, or if redistributive concerns take primacy, then the policy response would involve the combination of more heavily subsidizing college-level degree programs - a supply-side issue-along with the demand-side issue of developing high skill jobs that encourage higher-educated Appalachians to remain in the region rather than migrate to higher returns in other areas of the United States. On the other hand, if agglomeration economies 
and externalities are most pronounced in other metro areas of the country, and tastes for redistribution weak, then policies that foster migration to those high return areas are likely to be most cost effective. To more effectively inform policy on efficiency grounds, further evidence is needed on the presence or absence of region-specific externalities. 


\section{References}

Albrecht, James, Aico van Vuuren, and Susan Vroman. 2008. "Counterfactual Distributions with Sample Selection Adjustments: Econometric Theory and an Application to the Netherlands." Mimeo, Georgetown University.

Altonji, Joseph, and Rebecca Blank. 1999. "Race and Gender in the Labor Market.” in O. Ashenfelter and D. Card,(eds), Handbook of Labor Economics Volume 3c Elsevier Science B.V., 3144-3259.

Angrist, Joshua. 1990. "Lifetime Earnings and the Vietnam Draft Lottery: Evidence from Social Security Earnings Records.” American Economic Review 80(2): 313-336.

Autor, David, Lawrence Katz, and Melissa Kearney. 2005. "Rising Wage Inequality: The Role of Composition and Prices.” Mimeo, MIT.

Autor, David, Lawrence Katz, and Melissa Kearney. 2008. "Trends in U.S. Wage Inequality: Revising the Revisionists.” Review of Economics and Statistics 90(2): 300-323.

Azariadis, Costas, and John Stachurski. 2005. "Poverty Traps.” In Handbook of Economic Growth, P. Aghion and S. Durlauf, (eds.), Amsterdam: North Holland, Chapter 5.

Berger, Mark and Barry Hirsch. 1983. "The Civilian Earnings Experience of Vietnam-Era Veterans.” Journal of Human Resources 18(3): 455-479.

Black, Dan, Kermit Daniel, and Seth Sanders. 2002."The Impact of Economic Conditions on Disability Program Participation: Evidence from Coal Boom and Bust” American Economic Review 92(1): 27-50.

Black, Dan, Natalia Kolesnikova, and Lowell Taylor. 2009. "Earnings Functions when Wages and Prices vary by Location.” Journal of Labor Economics 27(1): 21-47.

Black, Dan A. and Seth G. Sanders. 2004. "Labor Market Performance, Poverty and Income Inequality in Appalachia” Population Reference Bureau (and University of Maryland).

Blanchard, Olivier and Lawrence Katz. 1992. "Regional Evolutions." Brookings Papers on Economic Activity 1:1-75.

Blinder, Alan S. 1973. "Wage Discrimination: Reduced Form and Structural Estimates" in Darity, William, Jr., ed. Economics and discrimination. Volume 2. Elgar Reference Collection.

Blundell, Richard, Amanda Gosling, Hidehiko Ichimura, and Costas Meghir. 2006. "Changes in the Distribution of Male and Female Wages Accounting for Employment Composition Using Bounds.” Econometrica 75(2): 323-363. 
Blundell, Richard, and Thomas MaCurdy. 1999. "Labor Supply: A Review of alternative Approaches.” In Handbook of Labor Economics, Volume 3A, Orley Ashenfelter and David Card, editors, Amsterdam: North-Holland, 1559-1695.

Bollinger, Christopher, and Barry Hirsch. 2006. "Match Bias from Earnings Imputation in the Current Population Survey: The Case of Imperfect Matching.” Journal of Labor Economics 24(3): 483-520

Borjas, George. 2004. “The Rise of Low-Skilled Immigration in the South.” University of Kentucky Center for Poverty Research Discussion Paper 2004-01.

Bound, John and George Johnson. 1992. "Changes in the Structure of Wages in the 1980s: An Evaluation of Alternative Explanations.” American Economic Review 82(3):371-92.

Bound, John, and Richard Burkhauser. 1999. "Economic Analysis of Transfer Programs Targeted on People with Disabilities.” In O. Ashenfelter and D. Card, editors, Handbook of Labor Economics, Volume 3C, Amsterdam: North Holland, 3417-3528.

Bowles, Samuel, Steven Durlauf, and Karla Hoff. 2006. Poverty Traps, Princeton, NJ: Princeton University Press.

Buchinsky, Moshe. 1998. "The Dynamics of Changes in the Female Wage Distribution in the USA: A Quantile Regression Approach.” Journal of Applied Econometrics 13: 1-30.

Buchinsky, Moshe. 2001. “Quantile Regression with Sample Selection: Estimating Women’s Return to Education in the U.S.” Empirical Economics 26: 87-113.

Card, David. 1999. “The Causal Effect of Education on Earnings.” in Handbook of Labor Economics, Vol 3A, O. Ashenfelter and D. Card (eds.), Amsterdam: North Holland, Ch. 30.

Card, David, and John DiNardo. 2002. "Skill-Biased Technological Change and Rising Wage Inequality: Some Problems and Puzzles.” Journal of Labor Economics 20: 733-783.

Card, David, and Alan Krueger. 1992. "Does School Quality Matter? Returns to Education and the Characteristics of Public Schools in the United States.” Journal of Political Economy 100(1): $1-40$.

Caudill, Harry. 1962. Night Comes to the Cumberlands, New York: Little, Brown.

Chandra, Amitabh. 2003. “Is the Racial Wage Gap Illusory?” National Bureau of Economic Research Working Paper 9476.

Chung, Chul, Jeremy Clark and Bonggeun Kim. 2009. “Is the Growing Skill Premium a Purely Metropolitan Issue?” Economics Letters 102: 73-75. 
Dahl, Gordon. 2002. "Mobility and the Return to Education: Testing a Roy Model with Multiple Markets.” Econometrica 70(6): 2367-2420.

Datta Gupta, Nabanita, Ronald Oaxaca, and Nina Smith. 1998. "Wage Dispersion, Public Sector Wages, and the Stagnating Danish Gender Wage Gap.” Center for Labor Market and Social Research Working Paper 98-18, University of Aarhus.

DiNardo, John, Nicole Fortin and Thomas Lemieux. 1996. "Labor Market Institutions and the Distribution of Wages, 1973-1992: A Semiparametric Approach.” Econometrica 64 (September), 1001-1044.

Duncan, Cynthia. 1999. Worlds Apart: Why Poverty Persists in Rural America. New Haven: Yale University Press.

DuMond, J. Michael, Barry Hirsch, and David Macpherson. 1999. "Wage Differential Across Labor Markets and Workers: Does Cost of Living Matter?” Economic Inquiry 37(4): 577-598.

Eller, Ronald D. 2008. Uneven Ground: Appalachia Since 1945. Lexington, Ky.: University of Kentucky Press.

Easterly, William. 2001. The Elusive Quest for Growth: Economists' Adventures and Misadventures in the Tropics, Cambridge, MA: MIT Press.

Firpo, Sergio, Nicole Fortin, and Thomas Lemieux. 2007. "Decomposing Wage Distributions Using Recentered Influence Function Regressions.” Mimeo, University of British Columbia.

Glaeser, Edward, and Joshua Gottlieb. 2008. "The Economics of Place-Making Policies.” National Bureau of Economic Research Working Paper 14373.

Groves, Robert M., Floyd J. Fowler, Jr., Mick P. Couper, James M. Lepkowski, Eleanor Singer, and Roger Tourangeau. 2004. Survey Methodology. John Wiley and Sons, New York.

Haaga, John. 2004. “The Aging of Appalachia.” Population Reference Bureau.

Harrington, Michael. 1962. The Other America. New York: Macmillan.

Haveman, Robert, Mark Stone, and Barbara Wolfe. 1994. "Market Work, Wages, and Men's Health." Journal of Health Economics 13(2): 163-182.

Heckman, James. 1979. “Sample Selection Bias as Specification Error.” Econometrica 47:1, 153-161.

Heckman, James, and Paul LaFontaine. 2007. "The American High School Graduation Rate: Trends and Levels.” National Bureau of Economic Research Working Paper 13670. 
Heckman, James, Lance Lochner, and Petra Todd. 2003. "Fifty Years of Mincer Earnings Regressions.” National Bureau of Economic Research Working Paper 9732.

Hotz, V. Joseph, and John Karl Scholz. 2003. “The Earned Income Tax Credit.” In Means-Tested Transfer Programs in the United States, R. Moffitt (ed.), Chicago: The University of Chicago Press and NBER, 141-197.

Ichimura, Hidehiko. 1993. "Semiparametric Least Squares (SLS) and Weighted SLS Estimation of Single-Index Models.” Journal of Econometrics 58:71-120.

Jann, B. 2005. "Standard Errors for the Blinder-Oaxaca Decomposition.” http://repec.org/dsug2005/oaxaca_se_handout.pdf.

Jones, F.L. 1983. “On Decomposing the Wage Gap: A Critical Comment on Blinder’s Method,” Journal of Human Resources 18(1): 126-131.

Juhn, Chinhui, Kevin Murphy, and Brooks Pierce. 1993. "Wage Inequality and the Rise in Returns to Skill” Journal of Political Economy 101(3): 410-42

Katz, Lawrence F. and Kevin M. Murphy. 1992. "Changes in Relative Wages, 1963-87: Supply and Demand Factors.” Quarterly Journal of Economics 107(1): 35-78.

Lee, David. 1999. "Wage Inequality in the United States during the 1980s: Rising Dispersion or Falling Minimum Wage?” Quarterly Journal of Economics 114(3): 977-1023.

Lee, Lung-Fei. 1984. "Tests for the Bivariate Normal Distribution in Econometric Models with Selectivity.” Econometrica 52:4, 843-863.

Lemieux, Thomas. 2002. "Decomposing Changes in Wage Distribution: A Unified Approach," Canadian Journal of Economics, 35(4), November, 646-688.

Lemieux, Thomas. 2006. "Increasing Residual Wage Inequality: Composition effects, Noisy Data, or Rising Demand for Skill?” American Economic Review 96(3): 461-498.

Machado, José and José Mata. 2005. "Counterfactual Decompositions of Changes in Wage Distribution Using Quantile Regression.” Journal of Applied Econometrics, 20(4), 445-65.

Meyer, Bruce and Dan Rosenbaum. 2001. "Welfare, the Earned Income Tax Credit, and the Labor Supply of Single Mothers.” Quarterly Journal of Economics 116(3): 1063-1114.

Moretti, Enrico. 2004. "Human Capital Externalities in Cities” In V. Henderson and J.F. Thisse, eds., Handbook of Urban and Regional Economics, vol. 4 Amsterdam: North Holland.

Moretti, Enrico. 2008. “Real Wage Inequality.” NBER Working Paper 14370.

Neal, Derek. 2004. “The Measured Black-White Wage Gap among Women is too Small.” Journal of Political Economy 112: S1-S28. 
Neuman, Shoshana and Ronald Oaxaca. 2004. "Wage Decompositions with SelectivityCorrected Wage Equations: A Methodological Note.” Journal of Economic Inequality 2: 3-10.

Oaxaca, Ronald. 1973. "Male-Female Wage Differentials in Urban Labor Markets.” International Economic Review 14(3): 693-709.

Olsen, Randall. 1980. “A Least Squares Correction for Selectivity Bias.” Econometrica 48(7): 1815-1820.

Parente, Stephen and Edward Prescott. 2005. "A Unified Theory of the Evolution of International Income Levels.” In The Handbook of Economic Growth, P. Aghion and S. Durlauf (eds.), Amsterdam: North Holland, 1371-1416.

Pollard, Kelvin M. 2003. “Appalachia at the Millennium: An Overview of Results from Census 2000.” Population Reference Bureau.

Wilson, William J. 1987. The Truly Disadvantaged: The Inner City, the Underclass, and Public Policy. Chicago, IL: University of Chicago Press.

Wooldridge, Jeffrey M. 2001. Econometric Analysis of Cross Section and Panel Data. Cambridge, MA: MIT Press.

Ziliak, James P. 2007. "Human Capital and the Challenge of Persistent Poverty in Appalachia." Economic Commentary, Federal Reserve Bank of Cleveland. 


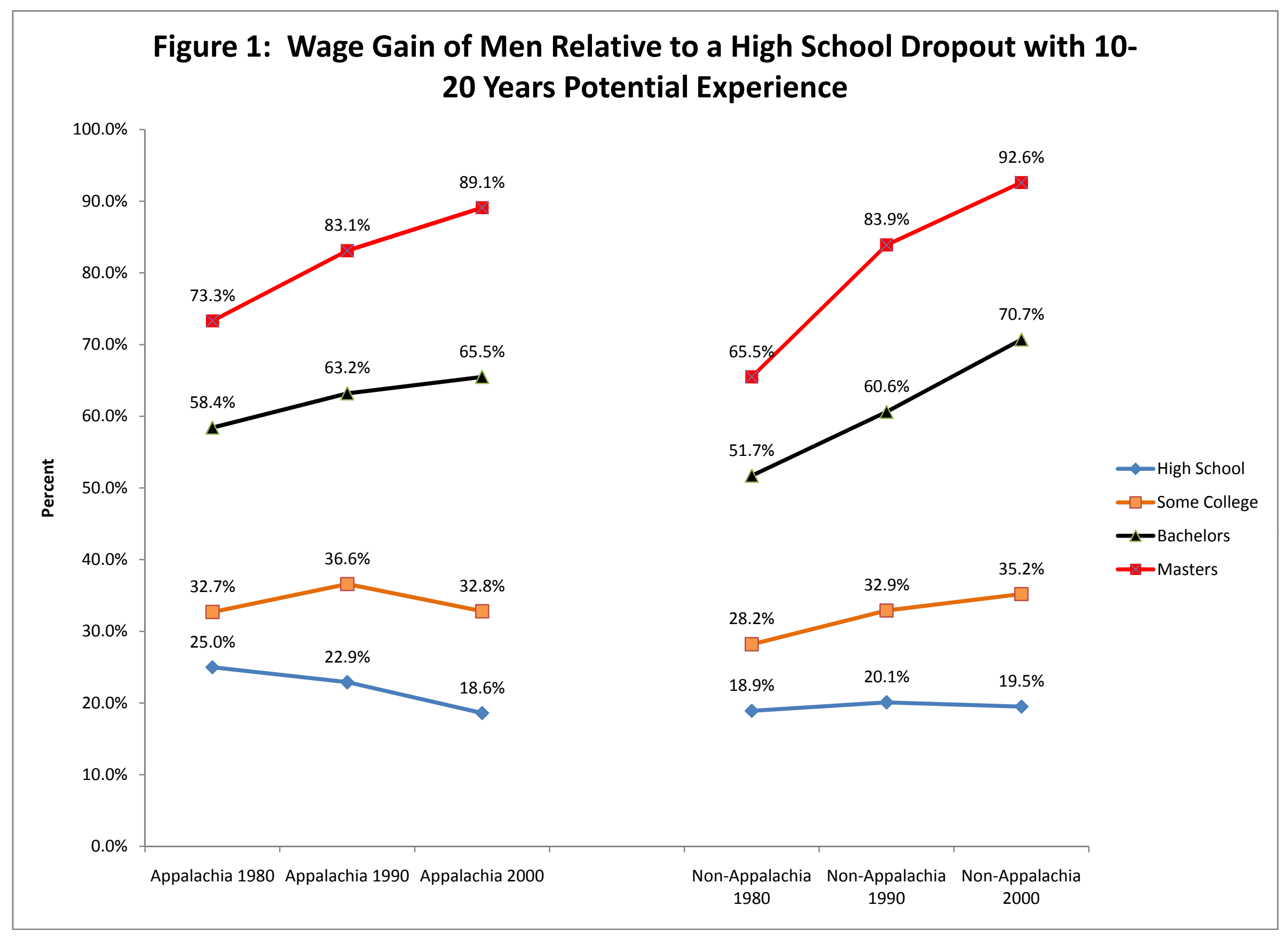




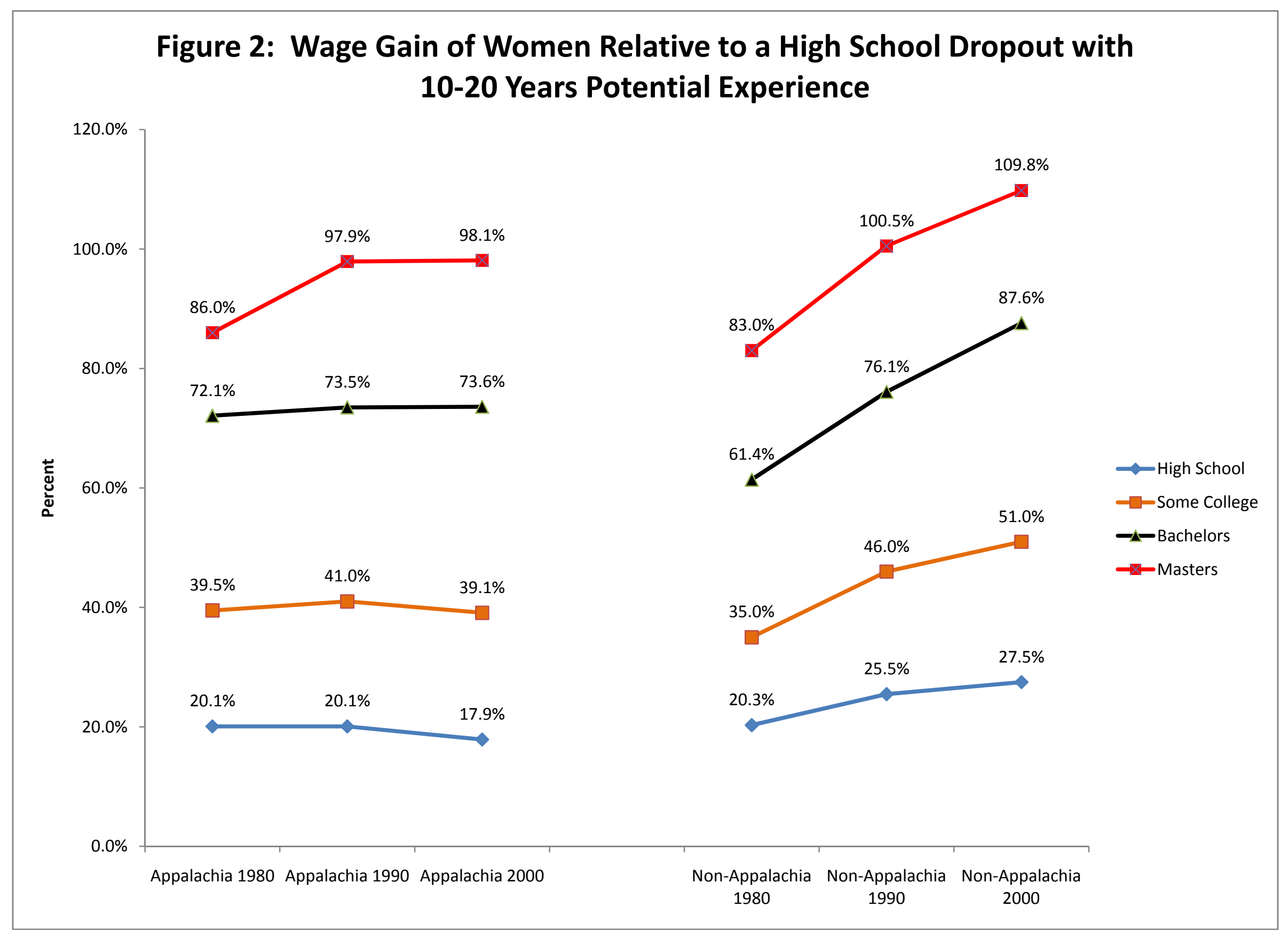




\section{Figure 3: Male Distribution Comparison Using Non-Appalachia as Counterfactual}
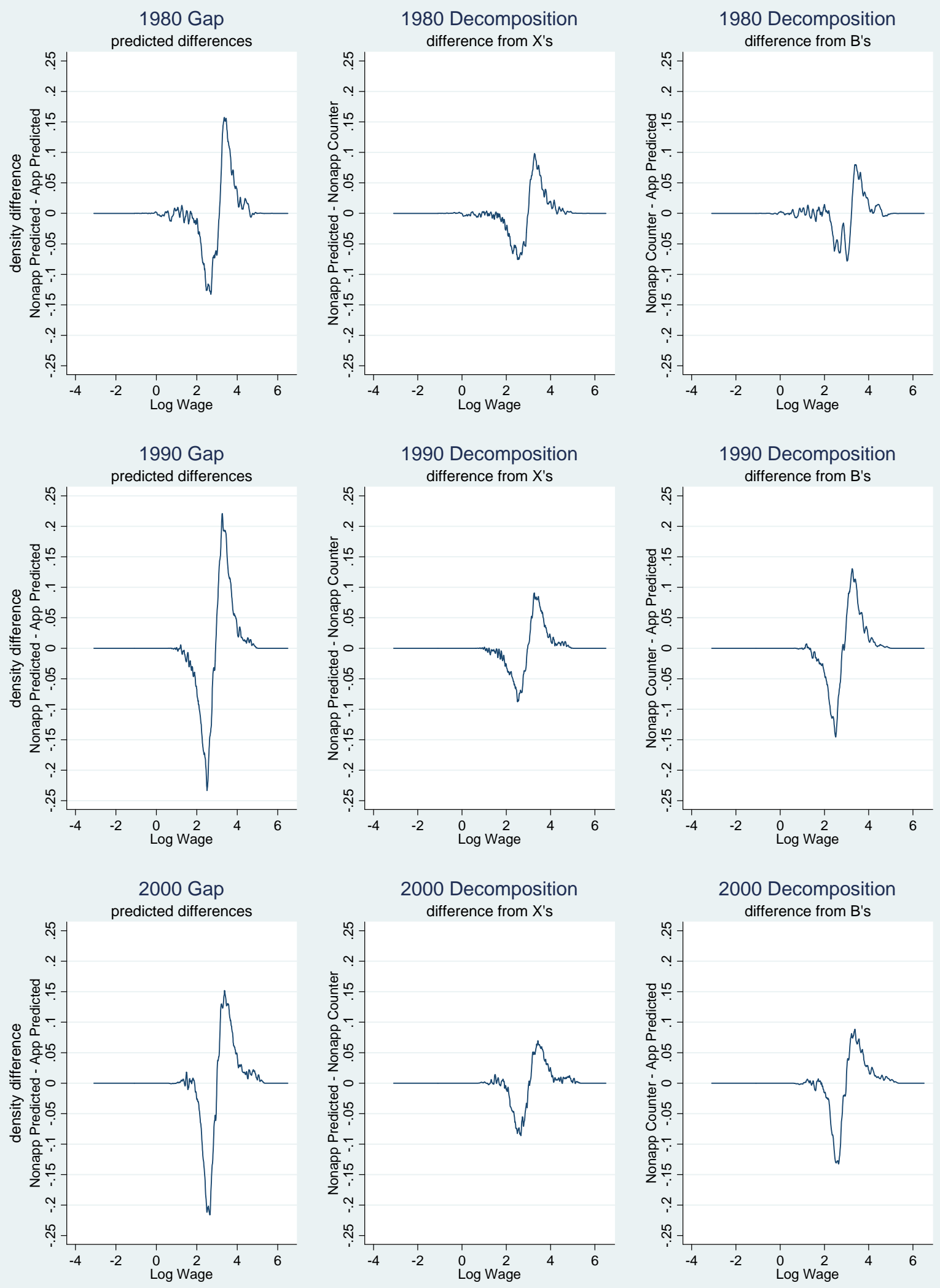


\section{Figure 4: Female Distribution Comparison Using Non-Appalachia as Counterfactual}
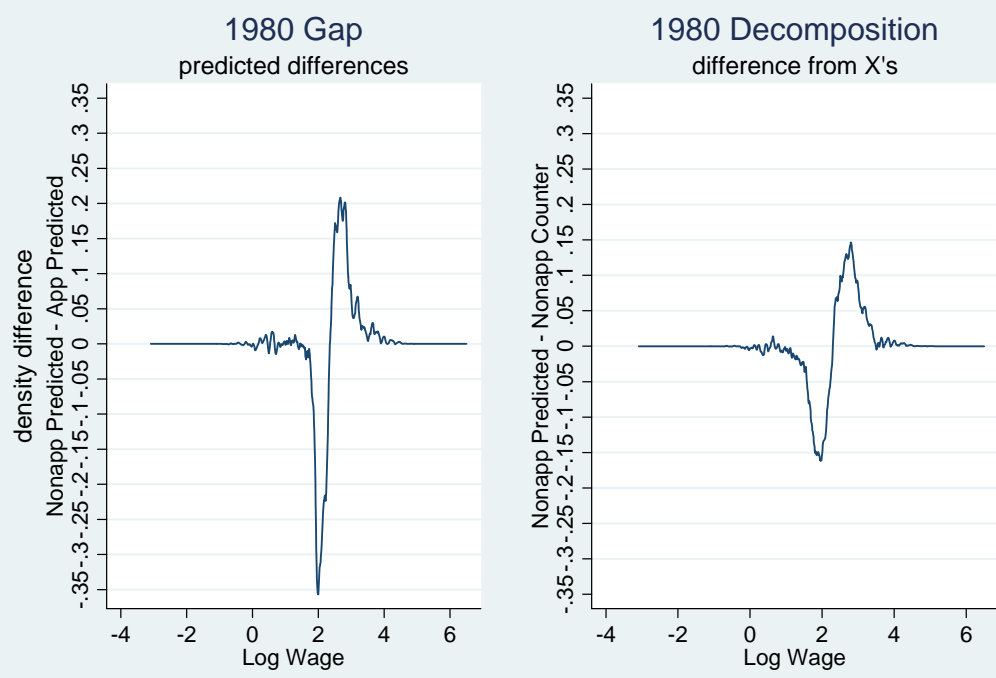

1990 Gap

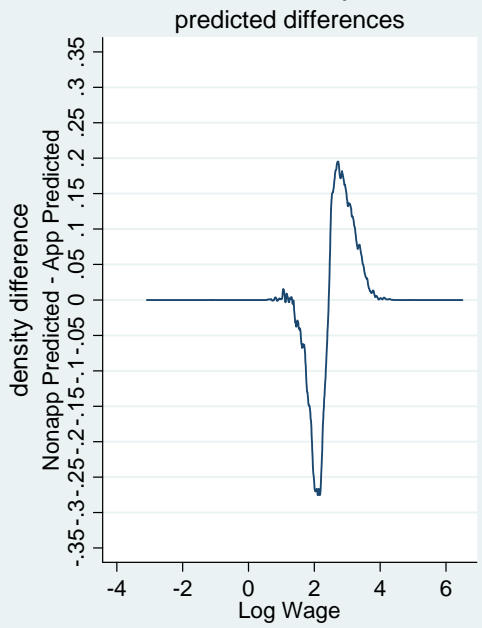

2000 Gap predicted differences

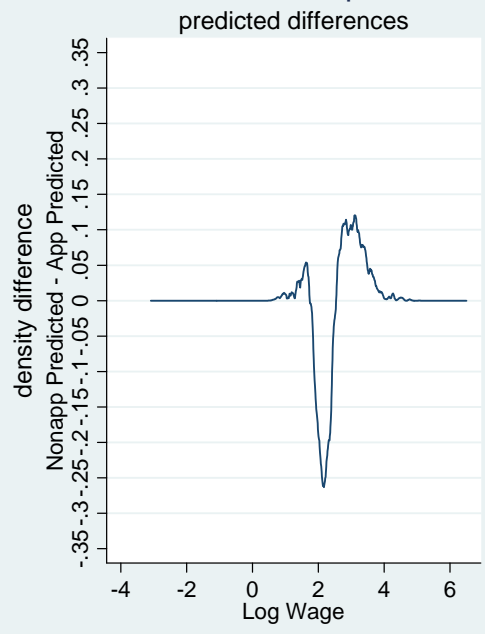

1980 Decomposition difference from B's

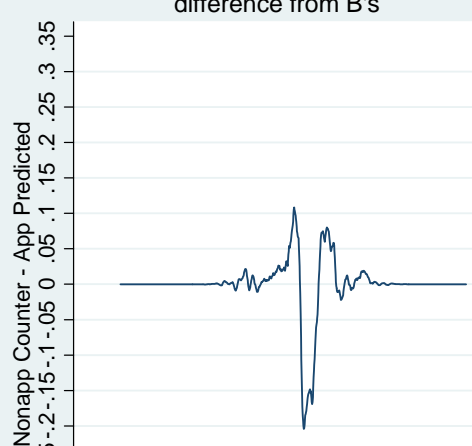

\begin{tabular}{llllll}
\hline & & 1 & 1 & 1 & 1 \\
-4 & -2 & 0 & 2 & 4 & 6
\end{tabular}

1990 Decomposition difference from B's
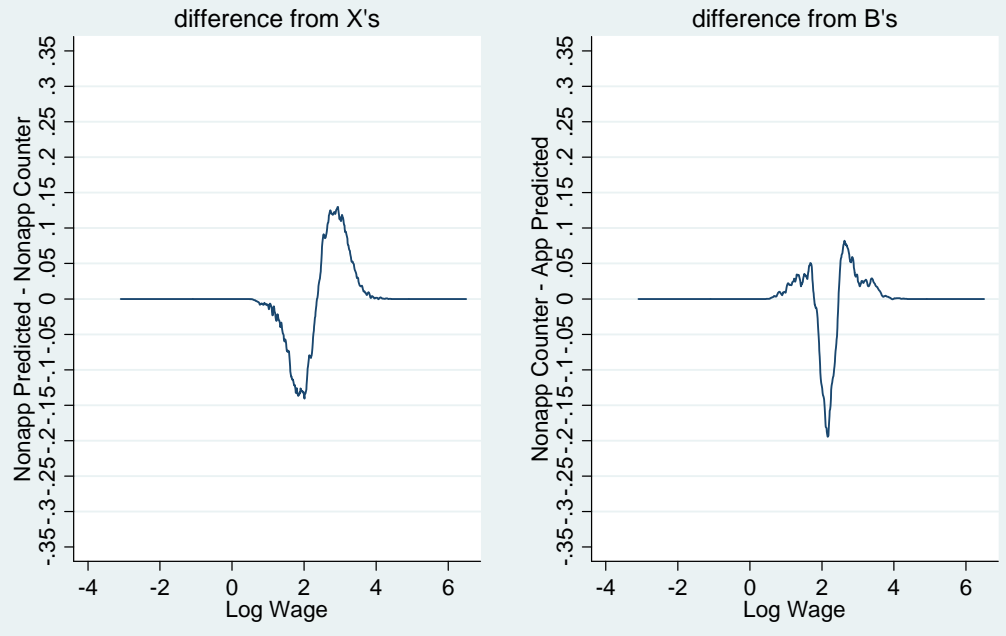

2000 Decomposition difference from B's
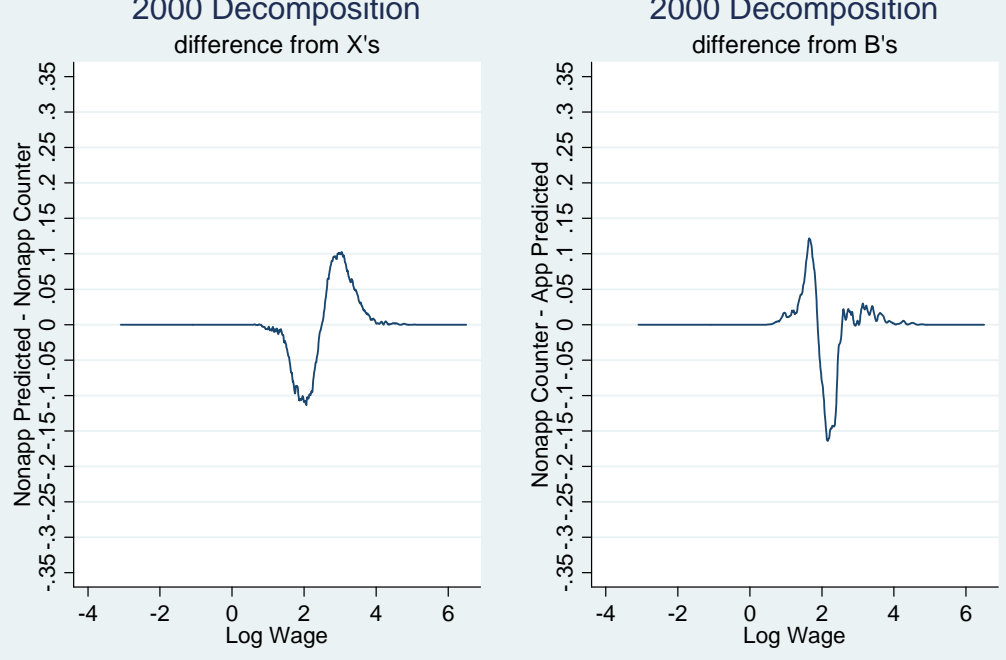
Table 1: Average Values of Selected Variables of Men within and outside Appalachia

Log of Real Wage

Wage Gap (Non-App less App)

Employment Rate

Usual Hours Worked per Week

Less than high school

High School

Some College

Bachelors Degree

Masters or more

Potential Experience $<=10$ years

Potential Experience $>10$ years $\&<=20$ years

Potential Experience $>20$ years $\&<=30$ years

Potential Experience $>30$ years $\&<=40$ years Appalachia Non-Appalachia Appalachia Non-Appalachia

\begin{tabular}{|c|c|c|c|c|c|}
\hline Appalachia & Non-Appalachia & Appalachia & Non-Appalachia & Appalachia & Non-Appalachia \\
\hline 1980 & 1980 & 1990 & 1990 & 2000 & 2000 \\
\hline \multirow{2}{*}{2.689} & 2.783 & 2.628 & 2.754 & 2.691 & 2.814 \\
\hline & 0.095 & & 0.126 & & 0.123 \\
\hline 0.890 & 0.914 & 0.884 & 0.912 & 0.860 & 0.890 \\
\hline 37.752 & 39.118 & 38.311 & 40.068 & 38.019 & 39.576 \\
\hline 0.334 & 0.241 & 0.211 & 0.154 & 0.154 & 0.131 \\
\hline 0.380 & 0.336 & 0.414 & 0.326 & 0.420 & 0.320 \\
\hline 0.132 & 0.190 & 0.212 & 0.274 & 0.244 & 0.286 \\
\hline 0.107 & 0.153 & 0.107 & 0.158 & 0.120 & 0.169 \\
\hline 0.048 & 0.080 & 0.057 & 0.089 & 0.063 & 0.094 \\
\hline 0.193 & 0.232 & 0.153 & 0.188 & 0.129 & 0.150 \\
\hline 0.285 & 0.293 & 0.346 & 0.360 & 0.288 & 0.307 \\
\hline 0.221 & 0.212 & 0.253 & 0.244 & 0.316 & 0.312 \\
\hline 0.208 & 0.196 & 0.186 & 0.163 & 0.218 & 0.195 \\
\hline 0.092 & 0.067 & 0.063 & 0.045 & 0.050 & 0.036 \\
\hline 0.931 & 0.809 & 0.932 & 0.773 & 0.901 & 0.703 \\
\hline 0.004 & 0.060 & 0.005 & 0.089 & 0.009 & 0.060 \\
\hline 0.059 & 0.100 & 0.055 & 0.095 & 0.062 & 0.101 \\
\hline 0.000 & 0.001 & 0.000 & 0.002 & 0.000 & 0.002 \\
\hline 0.005 & 0.026 & 0.008 & 0.040 & 0.018 & 0.066 \\
\hline 0.000 & 0.004 & 0.000 & 0.001 & 0.009 & 0.067 \\
\hline 0.175 & 0.127 & 0.176 & 0.147 & 0.159 & 0.149 \\
\hline 0.247 & 0.203 & 0.204 & 0.162 & 0.197 & 0.143 \\
\hline 0.118 & 0.092 & 0.113 & 0.084 & 0.099 & 0.072 \\
\hline 0.097 & 0.097 & 0.099 & 0.091 & 0.096 & 0.091 \\
\hline 0.045 & 0.055 & 0.048 & 0.057 & 0.046 & 0.048 \\
\hline 0.086 & 0.102 & 0.106 & 0.118 & 0.117 & 0.127 \\
\hline 0.027 & 0.045 & 0.028 & 0.047 & 0.030 & 0.048 \\
\hline 0.045 & 0.066 & 0.064 & 0.093 & 0.079 & 0.118 \\
\hline 0.096 & 0.113 & 0.105 & 0.114 & 0.120 & 0.127 \\
\hline 0.064 & 0.100 & 0.057 & 0.087 & 0.058 & 0.078 \\
\hline 0.421 & 0.782 & 0.420 & 0.748 & 0.476 & 0.774 \\
\hline 0.814 & 0.765 & 0.746 & 0.694 & 0.688 & 0.651 \\
\hline
\end{tabular}

White, non-Hispanic

White, Hispanic

Black, non-Hispanic

Black, Hispanic

Other, non-Hispanic

Other, Hispanic

Fishing, Mining, \& Construction

Durable Goods Manufacturing

Nondurable Goods Manufacturing

Transport, Communication, and Other Utilities

Wholesale Trade

Retail Trade

Finance, Insurance, \& Real Estate

Business \& Repair Services

Professional \& Related Services

Public Administration

Live in Urban Area

0.814

0.765

0.746

0.694

0.688 
Table 1 continued: Average Values of Selected Variables of Women within and outside Appalachia

Log of Real Wage

Wage Gap (Non-App less App)

Employment Rate

Usual Hours Worked per Week

Less than high school

High School

Some College

Bachelors Degree

Masters or more

Potential Experience $<=10$ years

Potential Experience $>10$ years $\&<=20$ years

Potential Experience $>20$ years $\&<=30$ years

Potential Experience $>30$ years $\&<=40$ years

$\begin{array}{r}\text { Appalac } \\ 1980 \\ \hline 2.190\end{array}$

Potential Experience $>40$ years

White, non-Hispanic

White, Hispanic

Black, non-Hispanic

Black, Hispanic

Other, non-Hispanic

Other, Hispanic

Fishing, Mining, \& Construction

Durable Goods Manufacturing

Nondurable Goods Manufacturing

Transport, Communication, and Other Utilities

Wholesale Trade

Retail Trade

Finance, Insurance, \& Real Estate

Business \& Repair Services

Professional \& Related Services

Public Administration

Live in Urban Area

Currently Married

0.563

0.328

0.450

0.119

0.081

0.022

0.224

0.233

0.093

0.924

0.004

0.066

0.001

0.005

0.000

0.022

0.101

0.162

0.029

0.172

0.076

0.317

0.046

0.420

\begin{tabular}{cc}
1980 & 1990 \\
\hline 2.317 & 2.230 \\
0.127 & \\
0.629 & 0.690 \\
22.402 & 25.373 \\
0.245 & 0.193 \\
0.423 & 0.447 \\
0.179 & 0.223 \\
0.117 & 0.090 \\
0.036 & 0.048 \\
0.198 & 0.152 \\
0.294 & 0.331 \\
0.218 & 0.255 \\
0.219 & 0.197 \\
0.070 & 0.065 \\
0.800 & 0.925 \\
0.058 & 0.005 \\
0.110 & 0.062 \\
0.002 & 0.000 \\
0.027 & 0.008 \\
0.003 & 0.000 \\
0.026 & 0.026 \\
0.094 & 0.085 \\
0.086 & 0.128 \\
0.039 & 0.030 \\
0.028 & 0.023 \\
0.165 & 0.184 \\
0.079 & 0.062 \\
0.095 & 0.084 \\
0.327 & 0.336 \\
0.061 & 0.042 \\
0.769 & 0.417 \\
0.732 & 0.730 \\
\hline &
\end{tabular}

Non-Appalachia

Appalachia Appalachía

2000

20.242

0.165

0.286

0.020

0.054

0.775

0.730

2000

$\begin{array}{ccc}0.169 & & 0.159 \\ 0.743 & 0.724 & 0.76 \\ 27.632 & 27.354 & 29.014 \\ 0.146 & 0.128 & 0.114\end{array}$

27.632

0.146

0.363

0.289

0.139

0.062

0.180

0.344

0.249

0.177

0.050

0.763

0.082

0.110

0.002

0.042

0.001

0.030

0.072

0.072

0.039

0.030

0.168

0.088

0.110

0.333

0.058

0.739

0.681
27.354

0.128

0.408

0.280

0.119

0.064

0.132

0.286

0.307

0.226

0.049

0.897

0.007

0.072

0.000

0.019

0.006

0.023

0.084

0.080

0.032

0.021

0.182

0.066

0.086

0.379

0.047

0.475

0.688
0.159

0.114

0.314

0.317

0.171

0.084

0.149

0.300

0.306

0.207

0.039

0.696

0.056

0.119

0.002

0.068

0.059

0.027

0.064

0.055

0.040

0.025

0.158

0.083

0.117

0.370

0.061

0.769

0.646 
Table 2: Oaxaca-Blinder Decomposition of Offered Wage Gaps between non-Appalachians and Appalachians

\begin{tabular}{|c|c|c|c|c|c|c|c|c|c|}
\hline \multirow[b]{3}{*}{ Year } & \multirow[b]{3}{*}{$\begin{array}{l}\text { Difference in Offered } \\
\text { Wage (log points) (1) }\end{array}$} & \multicolumn{8}{|c|}{ Men } \\
\hline & & \multicolumn{4}{|c|}{ Non-Appalachia as Reference } & \multicolumn{4}{|c|}{ Appalachia as Reference } \\
\hline & & $\begin{array}{c}\text { Demographics } \\
\text { (2) }\end{array}$ & $\begin{array}{l}\text { Percent Due to } \\
\text { Demographics } \\
(3)\end{array}$ & $\begin{array}{c}\text { Coefficients } \\
(4)\end{array}$ & $\begin{array}{l}\text { Percent Due } \\
\text { to } \\
\text { Coefficients } \\
\text { (5) }\end{array}$ & $\begin{array}{c}\text { Demographics } \\
(6)\end{array}$ & $\begin{array}{c}\text { Percent Due to } \\
\text { Demographics } \\
(7)\end{array}$ & $\begin{array}{c}\text { Coefficients } \\
(8)\end{array}$ & $\begin{array}{c}\text { Percent Due } \\
\text { to } \\
\text { Coefficients } \\
\text { (9) }\end{array}$ \\
\hline 1980 & 0.101 & $\begin{array}{c}0.064 \\
(0.001)\end{array}$ & $63 \%$ & $\begin{array}{c}0.037 \\
(0.008)\end{array}$ & $37 \%$ & $\begin{array}{c}0.056 \\
(0.003)\end{array}$ & $55 \%$ & $\begin{array}{c}0.045 \\
(0.009)\end{array}$ & $45 \%$ \\
\hline 1990 & 0.156 & $\begin{array}{c}0.071 \\
(0.001)\end{array}$ & $46 \%$ & $\begin{array}{c}0.085 \\
(0.006)\end{array}$ & $54 \%$ & $\begin{array}{c}0.041 \\
(0.003)\end{array}$ & $26 \%$ & $\begin{array}{c}0.115 \\
(0.006)\end{array}$ & $74 \%$ \\
\hline \multirow[t]{3}{*}{2000} & 0.129 & $\begin{array}{c}0.056 \\
(0.001)\end{array}$ & $43 \%$ & $\begin{array}{c}0.074 \\
(0.006)\end{array}$ & $57 \%$ & $\begin{array}{c}0.027 \\
(0.002)\end{array}$ & $21 \%$ & $\begin{array}{c}0.102 \\
(0.007)\end{array}$ & $79 \%$ \\
\hline & & \multicolumn{8}{|c|}{ Women } \\
\hline & & \multicolumn{4}{|c|}{ Non-Appalachia as Reference } & \multicolumn{4}{|c|}{ Appalachia as Reference } \\
\hline Year & $\begin{array}{c}\text { Difference in Offered } \\
\text { Wage (log points) }\end{array}$ & Demographics & $\begin{array}{l}\text { Percent Due to } \\
\text { Demographics }\end{array}$ & Coefficients & $\begin{array}{l}\text { Percent Due } \\
\text { to } \\
\text { Coefficients }\end{array}$ & Demographics & $\begin{array}{l}\text { Percent Due to } \\
\text { Demographics }\end{array}$ & Coefficients & $\begin{array}{l}\text { Percent Due } \\
\text { to } \\
\text { Coefficients } \\
\end{array}$ \\
\hline 1980 & 0.092 & $\begin{array}{c}0.097 \\
(0.001)\end{array}$ & $105 \%$ & $\begin{array}{l}-0.005 \\
(0.013)\end{array}$ & $-5 \%$ & $\begin{array}{c}0.071 \\
(0.004)\end{array}$ & $77 \%$ & $\begin{array}{c}0.021 \\
(0.013)\end{array}$ & $23 \%$ \\
\hline 1990 & 0.137 & $\begin{array}{c}0.119 \\
(0.001)\end{array}$ & $87 \%$ & $\begin{array}{c}0.018 \\
(0.007)\end{array}$ & $13 \%$ & $\begin{array}{c}0.069 \\
(0.003)\end{array}$ & $50 \%$ & $\begin{array}{c}0.068 \\
(0.008)\end{array}$ & $50 \%$ \\
\hline 2000 & 0.094 & $\begin{array}{c}0.096 \\
(0.001)\end{array}$ & $102 \%$ & $\begin{array}{l}-0.002 \\
(0.008)\end{array}$ & $-2 \%$ & $\begin{array}{c}0.060 \\
(0.003)\end{array}$ & $64 \%$ & $\begin{array}{c}0.034 \\
(0.008)\end{array}$ & $36 \%$ \\
\hline
\end{tabular}

Note: Analytic standard errors are provided in parentheses. 


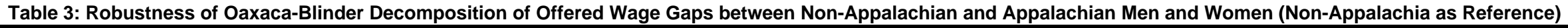

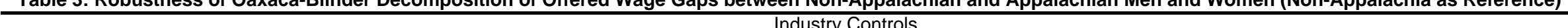

\begin{tabular}{|c|c|c|c|c|c|c|c|c|c|c|}
\hline \multirow[b]{3}{*}{ Year } & \multicolumn{10}{|c|}{ Industry Controls } \\
\hline & \multicolumn{5}{|c|}{ Men } & \multicolumn{5}{|c|}{ Women } \\
\hline & $\begin{array}{l}\text { Difference in Offered } \\
\text { Wage (log points) (1) }\end{array}$ & $\begin{array}{c}\text { Demographics } \\
\text { (2) }\end{array}$ & $\begin{array}{c}\text { Percent Due to } \\
\text { Demographics } \\
\text { (3) }\end{array}$ & $\begin{array}{l}\text { Coefficients } \\
\text { (4) }\end{array}$ & $\begin{array}{c}\text { Percent Due } \\
\text { to } \\
\text { Coefficients } \\
\text { (5) }\end{array}$ & $\begin{array}{l}\text { Difference in Offered } \\
\text { Wage (log points) (1) }\end{array}$ & $\begin{array}{l}\text { Demographics } \\
\text { (2) }\end{array}$ & $\begin{array}{l}\text { Percent Due to } \\
\text { Demographics } \\
\text { (3) }\end{array}$ & $\begin{array}{l}\text { Coefficients } \\
\text { (4) }\end{array}$ & $\begin{array}{c}\text { Percent Due } \\
\text { to } \\
\text { Coefficients } \\
\text { (5) }\end{array}$ \\
\hline 1980 & 0.103 & $\begin{array}{c}0.056 \\
(0.001)\end{array}$ & $54 \%$ & $\begin{array}{l}0.047 \\
(0.008)\end{array}$ & $46 \%$ & 0.100 & $\begin{array}{c}0.090 \\
(0.001)\end{array}$ & $90 \%$ & $\begin{array}{c}0.010 \\
(0.013)\end{array}$ & $10 \%$ \\
\hline 1990 & 0.159 & $\begin{array}{c}0.064 \\
(0.001)\end{array}$ & $40 \%$ & $\begin{array}{l}0.095 \\
(0.006)\end{array}$ & $60 \%$ & 0.153 & $\begin{array}{c}0.111 \\
(0.001)\end{array}$ & $73 \%$ & $\begin{array}{c}0.042 \\
(0.007)\end{array}$ & $27 \%$ \\
\hline \multirow[t]{2}{*}{2000} & 0.136 & $\begin{array}{c}0.049 \\
(0.001)\end{array}$ & $36 \%$ & $\begin{array}{l}0.087 \\
(0.006)\end{array}$ & $64 \%$ & 0.113 & $\begin{array}{l}0.092 \\
(0.001)\end{array}$ & $81 \%$ & $\begin{array}{l}0.021 \\
(0.007)\end{array}$ & $19 \%$ \\
\hline & \multicolumn{10}{|c|}{ Linear Probability Selection } \\
\hline & \multicolumn{5}{|c|}{ Men } & \multicolumn{5}{|c|}{ Women } \\
\hline Year & $\begin{array}{l}\text { Difference in Offered } \\
\text { Wage (log points) }\end{array}$ & Demographics & $\begin{array}{l}\text { Percent Due to } \\
\text { Demographics }\end{array}$ & Coefficients & $\begin{array}{c}\text { Percent Due } \\
\text { to } \\
\text { Coefficients }\end{array}$ & $\begin{array}{l}\text { Difference in Offered } \\
\text { Wage (log points) }\end{array}$ & Demographics & $\begin{array}{l}\text { Percent Due to } \\
\text { Demographics }\end{array}$ & Coefficients & $\begin{array}{c}\text { Percent Due } \\
\text { to } \\
\text { Coefficients }\end{array}$ \\
\hline 1980 & 0.113 & $\begin{array}{c}0.060 \\
(0.001)\end{array}$ & $53 \%$ & $\begin{array}{c}0.053 \\
(0.008)\end{array}$ & $47 \%$ & 0.102 & $\begin{array}{c}0.097 \\
(0.001)\end{array}$ & $95 \%$ & $\begin{array}{c}0.005 \\
(0.013)\end{array}$ & $5 \%$ \\
\hline 1990 & 0.160 & $\begin{array}{c}0.068 \\
(0.001)\end{array}$ & $43 \%$ & $\begin{array}{c}0.092 \\
(0.006)\end{array}$ & $58 \%$ & 0.143 & $\begin{array}{l}0.118 \\
(0.001)\end{array}$ & $83 \%$ & $\begin{array}{l}0.025 \\
(0.006)\end{array}$ & $17 \%$ \\
\hline \multirow[t]{4}{*}{2000} & 0.105 & $\begin{array}{c}0.055 \\
(0.001)\end{array}$ & $52 \%$ & $\begin{array}{c}0.051 \\
(0.006)\end{array}$ & $49 \%$ & 0.093 & $\begin{array}{l}0.096 \\
(0.001)\end{array}$ & $103 \%$ & $\begin{array}{l}-0.003 \\
(0.007)\end{array}$ & $-3 \%$ \\
\hline & \multicolumn{10}{|c|}{ Lee Quadratic Selection } \\
\hline & \multicolumn{5}{|c|}{ Men } & \multicolumn{5}{|c|}{ Women } \\
\hline & $\begin{array}{l}\text { Difference in Offered } \\
\text { Wage (log points) }\end{array}$ & Demographics & $\begin{array}{l}\text { Percent Due to } \\
\text { Demographics }\end{array}$ & Coefficients & $\begin{array}{c}\text { Percent Due } \\
\text { to } \\
\text { Coefficients }\end{array}$ & $\begin{array}{l}\text { Difference in Offered } \\
\text { Wage (log points) }\end{array}$ & Demographics & $\begin{array}{l}\text { Percent Due to } \\
\text { Demographics }\end{array}$ & Coefficients & $\begin{array}{c}\text { Percent Due } \\
\text { to } \\
\text { Coefficients }\end{array}$ \\
\hline 1980 & 0.017 & $\begin{array}{c}0.061 \\
(0.001)\end{array}$ & $359 \%$ & $\begin{array}{l}-0.044 \\
(0.015)\end{array}$ & $-259 \%$ & 0.112 & $\begin{array}{c}0.095 \\
(0.001)\end{array}$ & $85 \%$ & $\begin{array}{c}0.017 \\
(0.027)\end{array}$ & $15 \%$ \\
\hline 1990 & 0.180 & $\begin{array}{c}0.067 \\
(0.001)\end{array}$ & $37 \%$ & $\begin{array}{l}0.114 \\
(0.010)\end{array}$ & $63 \%$ & 0.204 & $\begin{array}{l}0.115 \\
(0.001)\end{array}$ & $56 \%$ & $\begin{array}{l}0.089 \\
(0.013)\end{array}$ & $44 \%$ \\
\hline 2000 & 0.126 & $\begin{array}{c}0.054 \\
(0.001)\end{array}$ & $43 \%$ & $\begin{array}{c}0.072 \\
(0.010)\end{array}$ & $57 \%$ & 0.053 & $\begin{array}{c}0.095 \\
(0.007)\end{array}$ & $179 \%$ & $\begin{array}{l}-0.042 \\
(0.014)\end{array}$ & $-79 \%$ \\
\hline
\end{tabular}

Note: Analytic standard errors are provided in parentheses 
Table 4: Actual Non-Appalachian - Appalachian Log Wage Gaps for Alternative Subregions

\begin{tabular}{|c|c|c|c|}
\hline & 1980 & 1990 & 2000 \\
\hline \multicolumn{4}{|l|}{ Men } \\
\hline Base Case & 0.095 & 0.126 & 0.123 \\
\hline Rural to Rural & -0.006 & -0.005 & 0.027 \\
\hline Urban to Urban & 0.062 & 0.114 & 0.097 \\
\hline Omit Urban Areas $>1,000,000$ & 0.049 & 0.040 & 0.058 \\
\hline Non-Appalachia to Central Appalachia & 0.125 & 0.168 & 0.175 \\
\hline Non-Appalachia (Omitting Urban Areas $>1,000,000$ ) to Central Appalachia & 0.044 & 0.059 & 0.078 \\
\hline \multicolumn{4}{|l|}{ Women } \\
\hline Base Case & 0.127 & 0.169 & 0.159 \\
\hline Rural to Rural & 0.013 & 0.010 & 0.031 \\
\hline Urban to Urban & 0.113 & 0.169 & 0.145 \\
\hline Omit Urban Areas > 1,000,000 & 0.059 & 0.061 & 0.072 \\
\hline Non-Appalachia to Central Appalachia & 0.155 & 0.213 & 0.205 \\
\hline Non-Appalachia (Omitting Urban Areas $>1,000,000$ ) to Central Appalachia & 0.067 & 0.083 & 0.086 \\
\hline
\end{tabular}




\begin{tabular}{|c|c|c|c|c|c|c|c|c|c|c|}
\hline \multirow[b]{2}{*}{ Year } & \multicolumn{10}{|c|}{ Rural to Rural Comparison } \\
\hline & $\begin{array}{l}\text { Difference in Offered } \\
\text { Wage (log points) (1) }\end{array}$ & $\begin{array}{c}\text { Demographics } \\
\text { (2) }\end{array}$ & $\begin{array}{l}\text { Percent Due to } \\
\text { Demographics } \\
\text { (3) }\end{array}$ & $\begin{array}{c}\text { Coefficients } \\
(4)\end{array}$ & 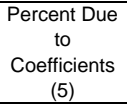 & $\begin{array}{l}\text { Difference in Offered } \\
\text { Wage (log points) }\end{array}$ & Demographics & $\begin{array}{l}\text { Percent Due to } \\
\text { Demographics }\end{array}$ & Coefficients & $\begin{array}{c}\text { Percent Due } \\
\text { to } \\
\text { Coefficients }\end{array}$ \\
\hline 1980 & -0.021 & $\begin{array}{c}0.000 \\
(0.001)\end{array}$ & $0 \%$ & $\begin{array}{l}-0.021 \\
(0.013)\end{array}$ & $100 \%$ & -0.069 & $\begin{array}{c}0.025 \\
(0.001)\end{array}$ & $-36 \%$ & $\begin{array}{l}-0.094 \\
(0.019)\end{array}$ & $136 \%$ \\
\hline 1990 & -0.012 & 0.000 & $0 \%$ & $\begin{array}{l}-0.012 \\
-0.006)\end{array}$ & $100 \%$ & -0.032 & 0.021 & $-66 \%$ & -0.053 & $166 \%$ \\
\hline 2000 & -0.018 & $\begin{array}{c}0.008 \\
(0.001)\end{array}$ & $-44 \%$ & $\begin{array}{l}-0.026 \\
(0.010)\end{array}$ & $144 \%$ & -0.020 & $\begin{array}{c}0.023 \\
(0.001)\end{array}$ & $-115 \%$ & $\begin{array}{l}-0.043 \\
(0.012)\end{array}$ & $215 \%$ \\
\hline & \multicolumn{10}{|c|}{ Urban to Urban Comparison } \\
\hline & \multicolumn{5}{|c|}{ Men } & \multicolumn{5}{|c|}{ Women } \\
\hline Year & $\begin{array}{l}\text { Difference in Offered } \\
\text { Wage (log points) (1) }\end{array}$ & $\begin{array}{c}\text { Demographics } \\
\text { (2) }\end{array}$ & $\begin{array}{l}\text { Percent Due to } \\
\text { Demographics } \\
\text { (3) }\end{array}$ & $\begin{array}{l}\text { Coefficients } \\
\text { (4) }\end{array}$ & $\begin{array}{l}\text { Percent Due } \\
\text { to } \\
\text { Coefficients } \\
\text { (5) }\end{array}$ & $\begin{array}{l}\text { Difference in Offered } \\
\text { Wage (log points) }\end{array}$ & Demographics & $\begin{array}{l}\text { Percent Due to } \\
\text { Demographics }\end{array}$ & Coefficients & $\begin{array}{c}\text { Percent Due } \\
\text { to } \\
\text { Coefficients }\end{array}$ \\
\hline 1980 & 0.101 & $\begin{array}{l}-0.009 \\
(0.001)\end{array}$ & $-9 \%$ & $\begin{array}{c}0.110 \\
(0.010)\end{array}$ & $109 \%$ & 0.095 & $\begin{array}{c}0.026 \\
(0.001)\end{array}$ & $27 \%$ & $\begin{array}{c}0.069 \\
(0.019)\end{array}$ & $73 \%$ \\
\hline 1990 & 0.172 & $\begin{array}{l}-0.018 \\
(0.001)\end{array}$ & $-10 \%$ & $\begin{array}{l}0.190 \\
(0.007)\end{array}$ & $110 \%$ & 0.153 & $\begin{array}{l}0.024 \\
(0.001)\end{array}$ & $16 \%$ & $\begin{array}{l}0.128 \\
(0.010)\end{array}$ & $84 \%$ \\
\hline 2000 & 0.126 & $\begin{array}{l}-0.024 \\
(0.001)\end{array}$ & $-19 \%$ & $\begin{array}{l}0.150 \\
(0.008)\end{array}$ & $119 \%$ & 0.098 & $\begin{array}{c}0.011 \\
(0.001)\end{array}$ & $11 \%$ & $\begin{array}{l}0.087 \\
(0.010)\end{array}$ & $89 \%$ \\
\hline & \multicolumn{10}{|c|}{ Base Case Comparison without Urban Areas $>1,000,000$} \\
\hline & \multicolumn{5}{|c|}{ Men } & \multicolumn{5}{|c|}{ Women } \\
\hline Year & $\begin{array}{l}\text { Difference in Offered } \\
\text { Wage (log points) (1) }\end{array}$ & $\begin{array}{c}\text { Demographics } \\
\text { (2) }\end{array}$ & $\begin{array}{l}\text { Percent Due to } \\
\text { Demographics } \\
\text { (3) }\end{array}$ & $\begin{array}{c}\text { Coefficients } \\
\text { (4) }\end{array}$ & $\begin{array}{c}\text { Percent Due } \\
\text { to } \\
\text { Coefficients } \\
\text { (5) }\end{array}$ & $\begin{array}{l}\text { Difference in Offered } \\
\text { Wage (log points) }\end{array}$ & Demographics & $\begin{array}{l}\text { Percent Due to } \\
\text { Demographics }\end{array}$ & Coefficients & $\begin{array}{c}\text { Percent Due } \\
\text { to } \\
\text { Coefficients }\end{array}$ \\
\hline 1980 & 0.074 & $\begin{array}{c}0.030 \\
(0.001)\end{array}$ & $41 \%$ & $\begin{array}{c}0.044 \\
(0.010)\end{array}$ & $59 \%$ & 0.004 & $\begin{array}{c}0.053 \\
(0.001)\end{array}$ & $1325 \%$ & $\begin{array}{l}-0.049 \\
(0.015)\end{array}$ & $-1225 \%$ \\
\hline 1990 & 0.059 & $\begin{array}{l}0.020 \\
(0.001)\end{array}$ & $34 \%$ & $\begin{array}{c}0.039 \\
(0.007)\end{array}$ & $66 \%$ & 0.027 & $\begin{array}{c}0.046 \\
(0.001)\end{array}$ & $170 \%$ & $\begin{array}{l}-0.019 \\
(0.008)\end{array}$ & $-70 \%$ \\
\hline \multirow[t]{4}{*}{2000} & 0.052 & $\begin{array}{l}0.022 \\
(0.001)\end{array}$ & $42 \%$ & $\begin{array}{l}0.030 \\
(0.007)\end{array}$ & $58 \%$ & 0.034 & $\begin{array}{c}0.043 \\
(0.001)\end{array}$ & $126 \%$ & $\begin{array}{l}-0.009 \\
(0.009)\end{array}$ & $-26 \%$ \\
\hline & \multicolumn{10}{|c|}{ Comparison of Non-Appalachia to Central Appalachian States } \\
\hline & \multicolumn{5}{|c|}{ 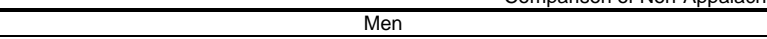 } & \multicolumn{5}{|c|}{ Women } \\
\hline & $\begin{array}{r}\text { Difference in Offered } \\
\text { Wage (log points) (1) }\end{array}$ & $\begin{array}{c}\text { Demographics } \\
\text { (2) }\end{array}$ & $\begin{array}{l}\text { Percent Due to } \\
\text { Demographics } \\
\text { (3) }\end{array}$ & $\begin{array}{c}\text { Coefficients } \\
(4)\end{array}$ & $\begin{array}{c}\begin{array}{c}\text { Percent Due } \\
\text { to } \\
\text { to } \\
\text { Coefficients } \\
\text { (5) }\end{array} \\
\end{array}$ & $\begin{array}{l}\text { Difference in Offered } \\
\text { Wage (log points) }\end{array}$ & Demographics & $\begin{array}{l}\text { Percent Due to } \\
\text { Demographics }\end{array}$ & Coefficients & $\begin{array}{c}\text { Percent Due } \\
\text { to } \\
\text { Coefficients }\end{array}$ \\
\hline 1980 & 0.140 & $\begin{array}{c}0.108 \\
(0.001)\end{array}$ & $77 \%$ & $\begin{array}{c}0.032 \\
(0.014)\end{array}$ & $23 \%$ & 0.161 & $\begin{array}{c}0.145 \\
(0.002)\end{array}$ & $90 \%$ & $\begin{array}{c}0.016 \\
(0.021)\end{array}$ & $10 \%$ \\
\hline 1990 & 0.211 & 0.117 & $55 \%$ & $\begin{array}{r}0.094 \\
(0.009)\end{array}$ & $45 \%$ & 0.181 & $\begin{array}{l}0.174 \\
(0.001)\end{array}$ & $96 \%$ & $\begin{array}{c}0.006 \\
(0.011)\end{array}$ & $3 \%$ \\
\hline \multirow[t]{4}{*}{2000} & 0.173 & $\begin{array}{c}(0.001) \\
0.100 \\
(0.001)\end{array}$ & $58 \%$ & $\begin{array}{c}(0.009) \\
0.073 \\
(0.011)\end{array}$ & $42 \%$ & 0.104 & $\begin{array}{l}(0.001) \\
0.150 \\
(0.001)\end{array}$ & $144 \%$ & $\begin{array}{l}-0.046 \\
(0.014)\end{array}$ & $-44 \%$ \\
\hline & \multicolumn{10}{|c|}{ Comparison of Non-Appalachia excluding Urban Areas $>1,000,000$ to Central Ap } \\
\hline & \multicolumn{5}{|c|}{ Men } & \multicolumn{4}{|c|}{ Women } & \\
\hline & $\begin{array}{l}\text { Difference in Offered } \\
\text { Wage (log points) (1) }\end{array}$ & $\begin{array}{l}\text { Demographics } \\
\text { (2) }\end{array}$ & $\begin{array}{l}\text { Percent Due to } \\
\text { Demographics } \\
\text { (3) }\end{array}$ & $\begin{array}{l}\text { Coefficients } \\
\text { (4) }\end{array}$ & $\begin{array}{c}\text { Percent Due } \\
\text { to } \\
\text { Coefficients } \\
\text { (5) }\end{array}$ & $\begin{array}{l}\text { Difference in Offered } \\
\text { Wage (log points) }\end{array}$ & Demographics & $\begin{array}{l}\text { Percent Due to } \\
\text { Demographics }\end{array}$ & Coefficients & $\begin{array}{c}\text { Percent Due } \\
\text { to } \\
\text { Coefficients }\end{array}$ \\
\hline 1980 & 0.056 & $\begin{array}{c}0.043 \\
(0.001)\end{array}$ & $77 \%$ & $\begin{array}{c}0.012 \\
(0.014)\end{array}$ & $21 \%$ & 0.055 & $\begin{array}{c}0.071 \\
(0.001)\end{array}$ & $129 \%$ & $\begin{array}{l}-0.016 \\
(0.021)\end{array}$ & $-29 \%$ \\
\hline 1990 & 0.105 & $\begin{array}{l}0.033 \\
(0.001)\end{array}$ & $31 \%$ & $\begin{array}{l}0.072 \\
(0.009)\end{array}$ & $69 \%$ & 0.061 & $\begin{array}{l}0.065 \\
(0.001)\end{array}$ & $107 \%$ & $\begin{array}{l}-0.004 \\
(0.012)\end{array}$ & $-7 \%$ \\
\hline 2000 & 0.081 & $\begin{array}{c}0.030 \\
(0.001)\end{array}$ & $37 \%$ & $\begin{array}{c}0.051 \\
(0.011)\end{array}$ & $63 \%$ & 0.039 & $\begin{array}{c}0.056 \\
(0.001)\end{array}$ & $144 \%$ & $\begin{array}{l}-0.017 \\
(0.015)\end{array}$ & $-44 \%$ \\
\hline
\end{tabular}

Note: Analytic standard errors are provided in parentheses 


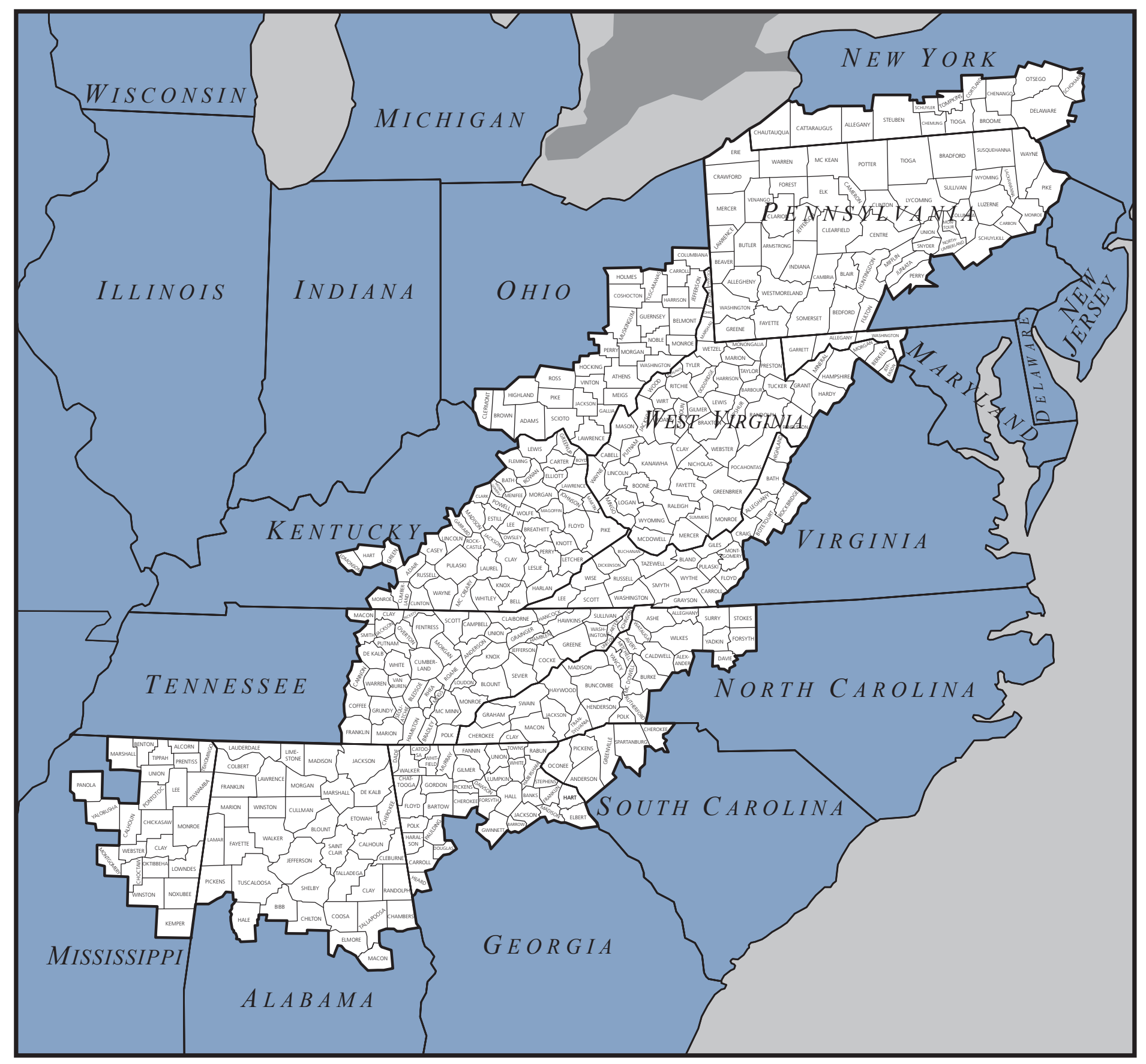

Appendix Figure 1: Map of Appalachian Counties (source: Appalachian Regional Commission) 


\section{Appendix Figure 2: Wage Gain of Men across Distribution}

Relative to High School Dropout with 10-20 Years Experience
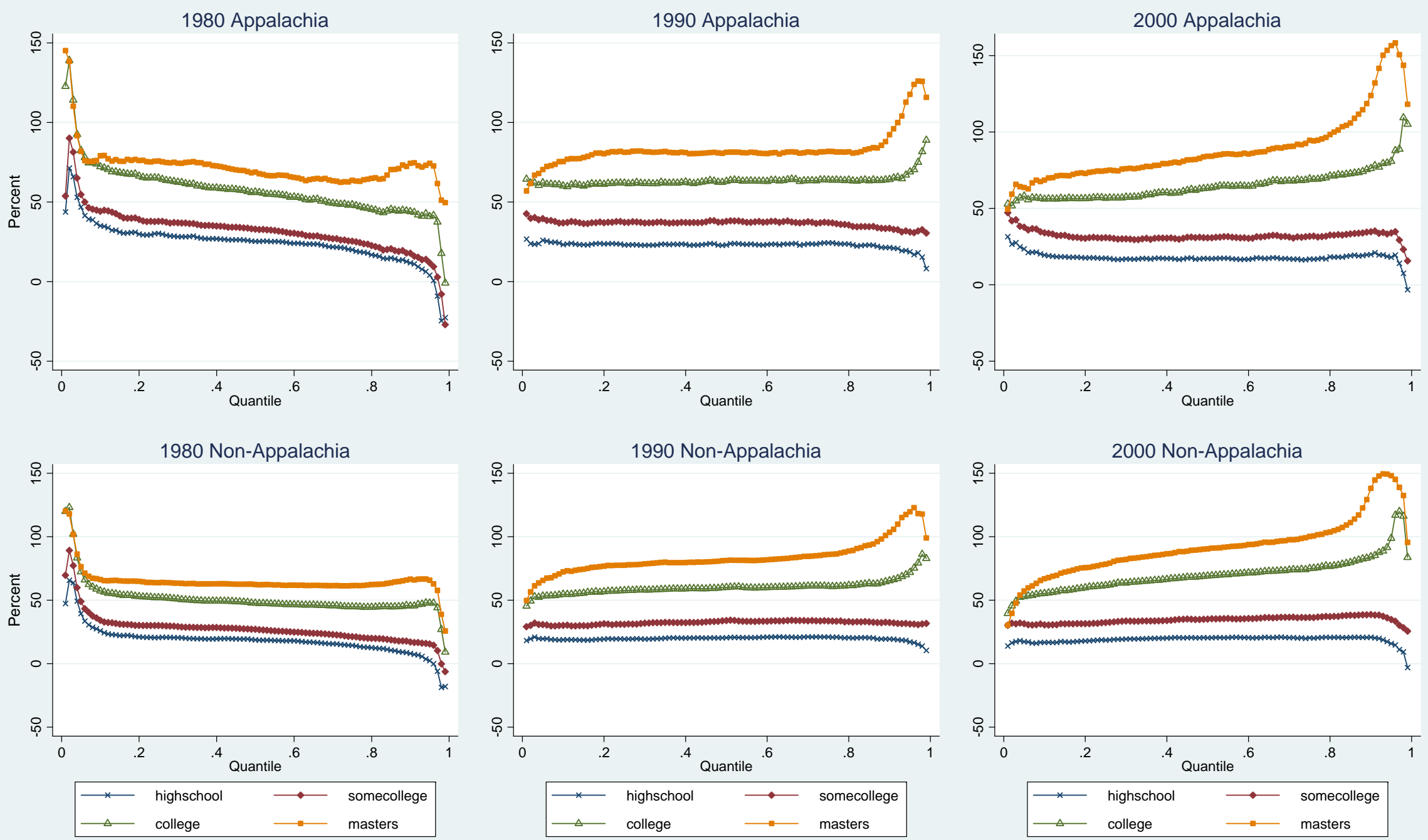


\section{Appendix Figure 3: Male Distribution Using Appalachia as Counterfactual}
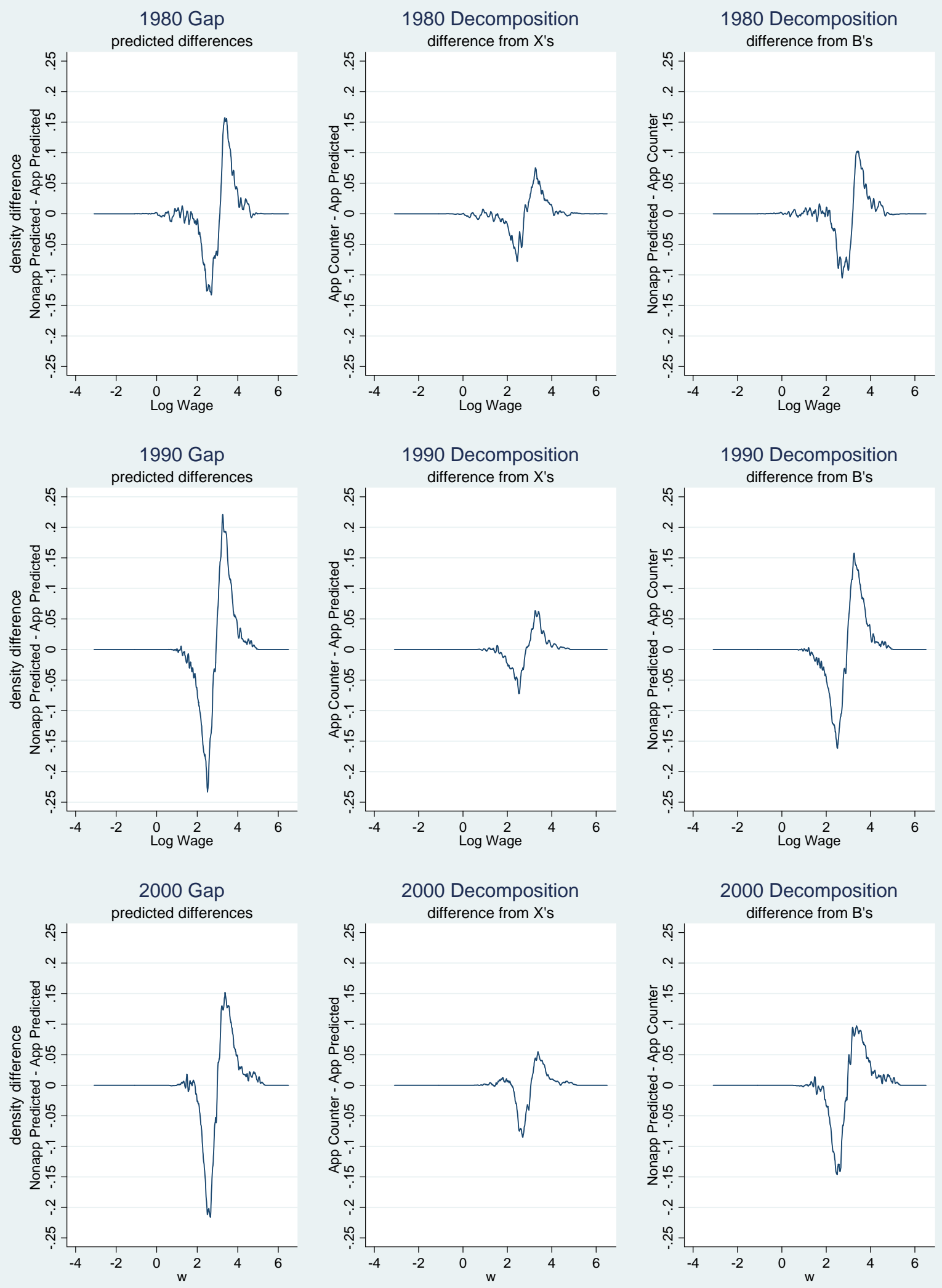


\section{Appendix Figure 4: Female Distribution Using Appalachia as Counterfactual}
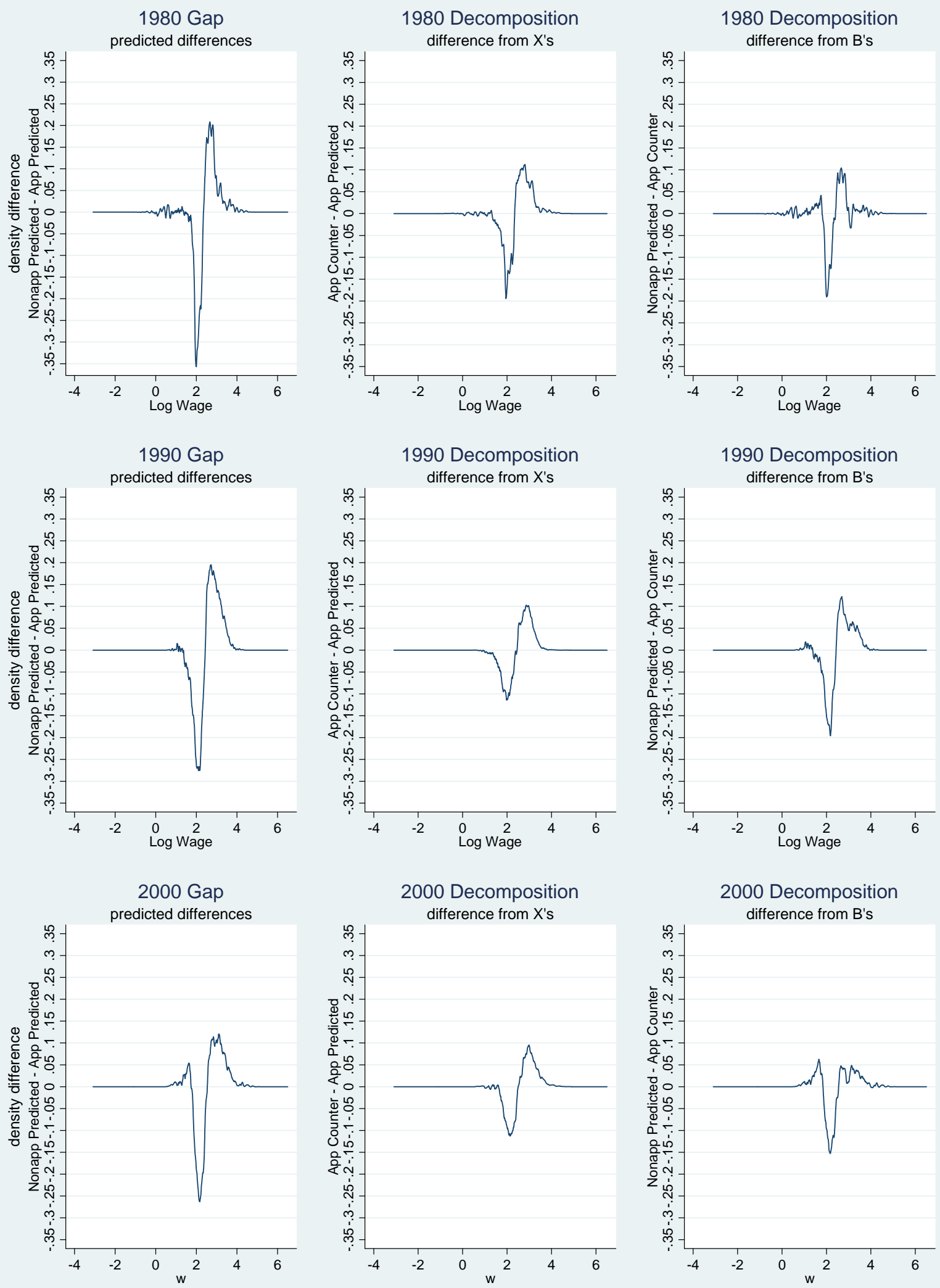


\section{Appendix Figure 5: Wage Gain of Women across Distribution}

Relative to High School Dropout with 10-20 Years Experience
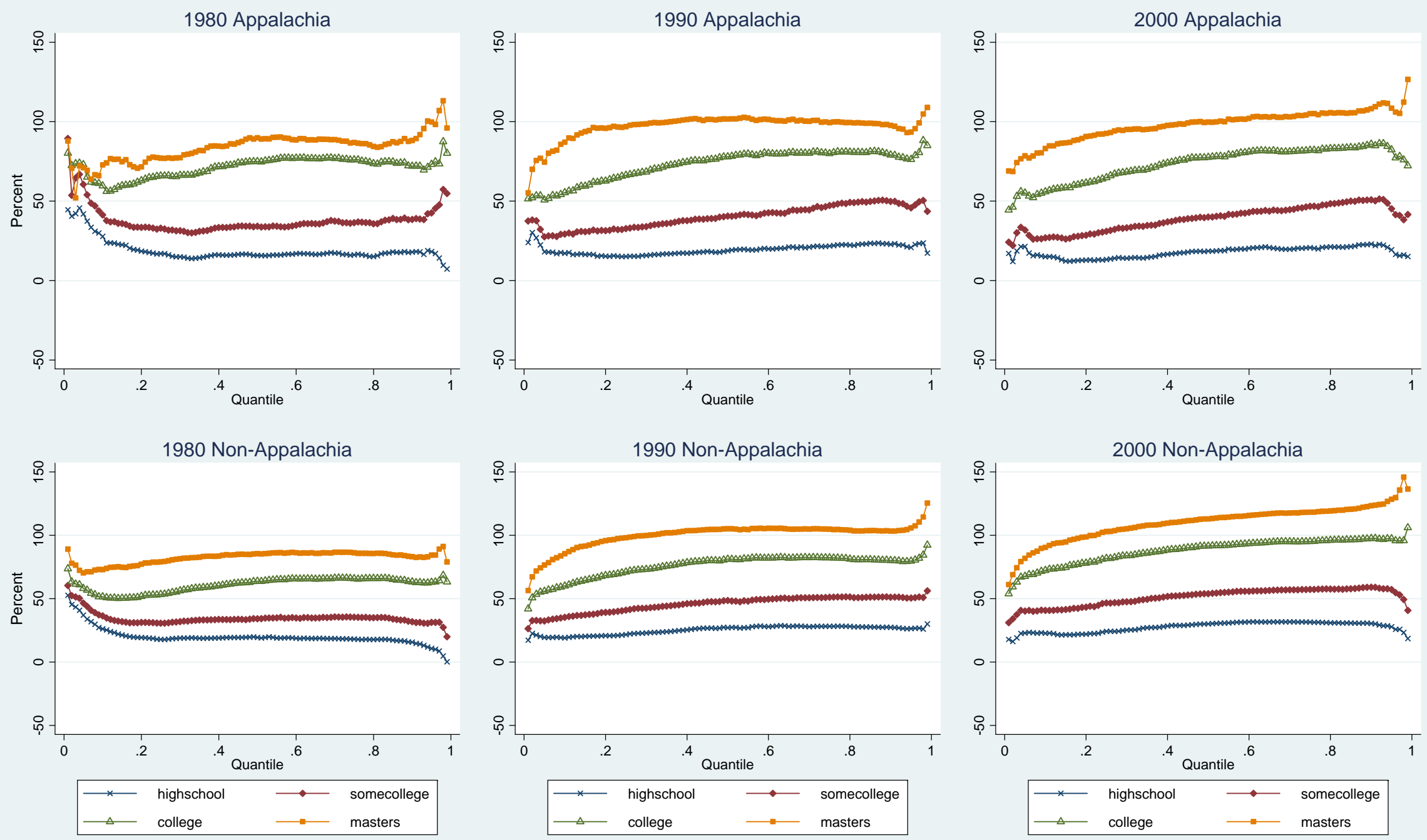


\begin{tabular}{|c|c|c|c|}
\hline & 1980 & 1990 & 2000 \\
\hline \multicolumn{4}{|l|}{ 5-Year Migration Rate (Overall) } \\
\hline \multicolumn{4}{|l|}{ Men } \\
\hline Move in to Appalachia & 0.011 & 0.011 & 0.011 \\
\hline Move out of Appalachia & 0.009 & 0.008 & 0.008 \\
\hline \multicolumn{4}{|l|}{ Women } \\
\hline Move in to Appalachia & 0.009 & 0.010 & 0.010 \\
\hline Move out of Appalachia & 0.008 & 0.008 & 0.007 \\
\hline \multicolumn{4}{|c|}{ 5-Year Migration Rate (Relative to Stayers in Appalachia) } \\
\hline \multicolumn{4}{|l|}{ Men } \\
\hline Move in to Appalachia & 0.105 & 0.104 & 0.109 \\
\hline Move out of Appalachia & 0.090 & 0.081 & 0.082 \\
\hline \multicolumn{4}{|l|}{ Women } \\
\hline Move in to Appalachia & 0.089 & 0.091 & 0.098 \\
\hline Move out of Appalachia & 0.078 & 0.074 & 0.075 \\
\hline \multicolumn{4}{|l|}{ Five-Year Stayer Rate } \\
\hline \multicolumn{4}{|l|}{ - } \\
\hline Live in Appalachia & 0.903 & 0.901 & 0.895 \\
\hline Live outside Appalachia & 0.988 & 0.989 & 0.990 \\
\hline \multicolumn{4}{|l|}{ Women } \\
\hline Live in Appalachia & 0.918 & 0.913 & 0.905 \\
\hline Live outside Appalachia & 0.989 & 0.990 & 0.991 \\
\hline \multicolumn{4}{|l|}{ Born in Appalachia } \\
\hline \multicolumn{4}{|l|}{ 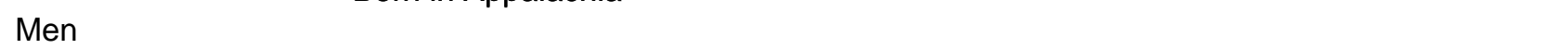 } \\
\hline Live in Appalachia & 0.926 & 0.904 & 0.861 \\
\hline Live outside Appalachia & 0.346 & 0.310 & 0.278 \\
\hline \multicolumn{4}{|l|}{ Women } \\
\hline Live in Appalachia & 0.920 & 0.900 & 0.859 \\
\hline Live outside Appalachia & 0.343 & 0.313 & 0.284 \\
\hline
\end{tabular}


Appendix Table 2: Education Attainment of Appalachians by Migration Status

\begin{tabular}{|c|c|c|c|c|c|c|}
\hline \multicolumn{7}{|c|}{ Appalachian Men } \\
\hline & 1980 stayer & 1980 mover in & 1980 mover out & 2000 stayer & 2000 mover in & 2000 mover out \\
\hline Less than high school & 0.36 & 0.17 & 0.14 & 0.16 & 0.13 & 0.08 \\
\hline High School & 0.38 & 0.28 & 0.24 & 0.44 & 0.28 & 0.24 \\
\hline Some College & 0.12 & 0.20 & 0.19 & 0.24 & 0.27 & 0.25 \\
\hline Bachelors Degree & 0.10 & 0.22 & 0.28 & 0.11 & 0.19 & 0.27 \\
\hline Masters or more & 0.04 & 0.13 & 0.15 & 0.05 & 0.13 & 0.15 \\
\hline \multicolumn{7}{|c|}{ Appalachian Women } \\
\hline & 1980 stayer & 1980 mover in & 1980 mover out & 2000 stayer & 2000 mover in & 2000 mover out \\
\hline Less than high school & 0.34 & 0.20 & 0.15 & 0.13 & 0.10 & 0.07 \\
\hline High School & 0.45 & 0.37 & 0.35 & 0.42 & 0.29 & 0.25 \\
\hline Some College & 0.11 & 0.20 & 0.20 & 0.28 & 0.32 & 0.30 \\
\hline Bachelors Degree & 0.07 & 0.18 & 0.23 & 0.11 & 0.20 & 0.25 \\
\hline Masters or more & 0.02 & 0.05 & 0.07 & 0.06 & 0.10 & 0.13 \\
\hline
\end{tabular}


Appendix Table 3: Estimated Wage Determinants for Men within and outside Appalachia

Constant 1980

\begin{tabular}{|c|c|c|c|c|c|}
\hline \multicolumn{2}{|c|}{1980} & \multicolumn{2}{|c|}{1990} & \multicolumn{2}{|c|}{2000} \\
\hline Non-Appalachia & Appalachia & Non-Appalachia & Appalachia & Non-Appalachia & Appalachia \\
\hline $2.294^{\star \star \star}$ & $2.255^{\star \star \star}$ & $2.105^{\star \star \star}$ & $2.013^{\star \star \star}$ & $2.169^{\star \star \star}$ & $2.120^{\star \star \star}$ \\
\hline$(0.009)$ & $(0.028)$ & $(0.006)$ & (0.018) & $(0.007)$ & $(0.020)$ \\
\hline $0.107^{\star \star \star}$ & $0.201^{\star \star *}$ & $0.127^{\star \star \star}$ & $0.150 * \star *$ & $0.116^{\star \star \star}$ & $0.131^{\star \star *}$ \\
\hline$(0.009)$ & $(0.027)$ & $(0.006)$ & $(0.016)$ & $(0.007)$ & $(0.019)$ \\
\hline $0.164^{* \star *}$ & $0.253^{\star \star \star}$ & 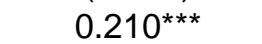 & $0.265^{\star \star \star}$ & $0.224^{\star \star \star}$ & $0.210^{\star \star \star *}$ \\
\hline$(0.009)$ & $(0.027)$ & $(0.006)$ & $(0.017)$ & $(0.007)$ & $(0.020)$ \\
\hline $0.318^{\star \star *}$ & $0.374^{\star \star \star}$ & $0.459 * \star \star$ & $0.486^{\star \star \star}$ & $0.515^{\star \star \star}$ & $0.425^{\star \star \star}$ \\
\hline (0.009) & $(0.028)$ & $(0.006)$ & $(0.017)$ & $(0.007)$ & $(0.020)$ \\
\hline $0.442^{\star \star \star}$ & $0.504^{\star \star \star}$ & $0.652^{\star \star \star}$ & $0.689 * \star \star$ & $0.698^{\star \star \star}$ & $0.607^{\star \star \star}$ \\
\hline (0.010) & $(0.032)$ & $(0.006)$ & (0.021) & $(0.007)$ & $(0.024)$ \\
\hline$-0.201^{\star \star \star}$ & 0.068 & $-0.228^{\star \star \star}$ & $-0.093^{\star \star \star}$ & $-0.216^{\star \star \star}$ & $-0.156^{\star \star \star}$ \\
\hline$(0.004)$ & (0.043) & $(0.002)$ & (0.024) & (0.002) & (0.018) \\
\hline$-0.151^{\star \star *}$ & $-0.215^{\star \star \star}$ & $-0.169 * \star \star$ & $-0.150 * \star \star$ & $-0.170^{* \star *}$ & -0.110 *** \\
\hline$(0.003)$ & $(0.013)$ & $(0.002)$ & $(0.007)$ & $(0.002)$ & $(0.006)$ \\
\hline$-0.242^{\star \star \star}$ & -0.149 & $-0.224^{\star \star \star}$ & $-0.284^{\star *}$ & $-0.212^{\star \star \star}$ & $-0.189^{*}$ \\
\hline$(0.027)$ & $(0.166)$ & $(0.011)$ & $(0.092)$ & $(0.011)$ & $(0.095)$ \\
\hline$-0.127^{\star \star \star}$ & 0.068 & $-0.145^{\star \star \star}$ & -0.016 & $-0.140^{\star \star \star}$ & $-0.086^{\star \star \star}$ \\
\hline (0.005) & (0.054) & (0.003) & (0.023) & (0.002) & (0.015) \\
\hline$-0.214^{\star \star *}$ & -0.152 & $-0.182^{\star \star \star}$ & -0.002 & $-0.238^{\star \star \star}$ & $-0.205^{\star \star \star}$ \\
\hline$(0.015)$ & (0.123) & $(0.013)$ & $(0.148)$ & (0.002) & $(0.022)$ \\
\hline $0.094^{\star \star \star}$ & $0.065^{\star}$ & $0.077^{\star \star \star *}$ & $0.097^{\star \star \star}$ & $0.039 * \star \star$ & $0.051^{* *}$ \\
\hline$(0.010)$ & $(0.027)$ & $(0.006)$ & $(0.016)$ & $(0.007)$ & $(0.020)$ \\
\hline $0.218^{\star \star \star}$ & $0.179 * \star \star$ & $0.199 * \star \star$ & $0.233^{\star \star \star}$ & $0.109 * \star \star$ & $0.175^{\star \star \star}$ \\
\hline (0.009) & (0.027) & $(0.006)$ & (0.017) & (0.007) & $(0.020)$ \\
\hline $0.309^{\star \star \star *}$ & $0.270 * \star \star$ & $0.298^{\star * *}$ & 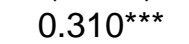 & $0.161^{\star * *}$ & $0.252^{\star \star \star}$ \\
\hline (0.009) & $(0.027)$ & $(0.006)$ & $(0.017)$ & $(0.007)$ & $(0.021)$ \\
\hline $0.323^{\star \star \star}$ & $0.270^{\star \star \star}$ & $0.316^{\star \star \star}$ & $0.326^{\star \star \star}$ & $0.160^{\star \star \star}$ & $0.287^{\star \star \star}$ \\
\hline (0.010) & $(0.030)$ & (0.007) & $(0.020)$ & (0.008) & $(0.024)$ \\
\hline $0.082^{\star \star \star}$ & 0.049 & $0.074^{\star \star \star}$ & $0.079^{\star \star \star}$ & $0.079 * \star \star$ & $0.055^{\star \star}$ \\
\hline$(0.010)$ & $(0.029)$ & $(0.006)$ & $(0.017)$ & $(0.007)$ & $(0.021)$ \\
\hline $0.075^{\star \star \star}$ & 0.023 & $0.113^{\star \star \star}$ & $0.108^{\star \star \star}$ & $0.111^{\star \star \star}$ & 0.059 ** \\
\hline$(0.010)$ & (0.029) & $(0.006)$ & (0.018) & $(0.007)$ & $(0.020)$ \\
\hline $0.043^{\star \star \star}$ & -0.014 & $0.072^{\star \star \star}$ & $0.070^{\star \star \star}$ & $0.114^{\star \star \star}$ & $0.065^{\star \star}$ \\
\hline (0.010) & (0.029) & $(0.006)$ & (0.018) & (0.007) & $(0.021)$ \\
\hline $0.070^{\star \star \star}$ & -0.037 & $0.064^{\star \star \star}$ & $0.057^{\star \star}$ & $0.109 * \star \star *$ & 0.048 \\
\hline (0.012) & (0.036) & (0.008) & $(0.022)$ & (0.009) & $(0.025)$ \\
\hline
\end{tabular}


Appendix Table 3 Men continued

Some College x Exper 10-20 1980

\begin{tabular}{|c|c|c|c|c|c|}
\hline \multicolumn{2}{|c|}{1980} & \multicolumn{2}{|c|}{1990} & \multicolumn{2}{|c|}{2000} \\
\hline Non-Appalachia & Appalachia & Non-Appalachia & Appalachia & Non-Appalachia & Appalachia \\
\hline $0.118^{\star \star \star}$ & $0.074^{*}$ & $0.119 * \star \star$ & $0.101^{\star \star \star}$ & $0.128^{\star \star \star}$ & $0.118^{\star \star \star}$ \\
\hline$(0.010)$ & $(0.031)$ & $(0.006)$ & $(0.018)$ & $(0.007)$ & $(0.021)$ \\
\hline $0.117^{\star \star \star}$ & 0.052 & $0.162^{* * *}$ & $0.124^{* * *}$ & $0.161^{\star \star \star}$ & $0.121^{\star \star \star}$ \\
\hline$(0.011)$ & $(0.032)$ & $(0.006)$ & $(0.018)$ & $(0.007)$ & $(0.021)$ \\
\hline $0.096 * \star \star$ & 0.017 & $0.122^{\star \star \star}$ & $0.076^{\star \star \star}$ & $0.155^{\star \star \star}$ & $0.109 * * *$ \\
\hline$(0.011)$ & $(0.034)$ & $(0.007)$ & $(0.019)$ & $(0.007)$ & $(0.021)$ \\
\hline $0.133^{\star \star \star}$ & 0.156 & $0.119 * * *$ & 0.009 & $0.148^{\star \star \star}$ & $0.121^{* *}$ \\
\hline$(0.032)$ & $(0.166)$ & $(0.013)$ & $(0.038)$ & $(0.012)$ & $(0.040)$ \\
\hline $0.199 * \star *$ & $0.210 * \star \star$ & $0.147^{* * *}$ & $0.146^{\star \star \star}$ & $0.192^{\star \star \star}$ & $0.230 * * \star$ \\
\hline$(0.010)$ & $(0.031)$ & $(0.006)$ & $(0.019)$ & $(0.007)$ & $(0.022)$ \\
\hline $0.225^{\star \star \star}$ & $0.204^{\star \star \star}$ & $0.196^{\star \star \star}$ & $0.184^{\star \star \star}$ & $0.164^{\star \star \star}$ & $0.196^{\star \star \star}$ \\
\hline$(0.011)$ & $(0.033)$ & $(0.007)$ & $(0.020)$ & $(0.007)$ & $(0.022)$ \\
\hline $0.158^{\star * \star}$ & $0.134^{\star * \star}$ & $0.150 * \star \star$ & $0.164^{\star * \star}$ & $0.147^{* \star *}$ & $0.199 * * *$ \\
\hline$(0.011)$ & $(0.036)$ & $(0.007)$ & $(0.024)$ & $(0.008)$ & $(0.025)$ \\
\hline $0.213^{\star \star \star}$ & $0.229 * \star \star$ & $0.187^{\star \star \star}$ & $0.142^{\star \star \star}$ & $0.228 * \star \star$ & $0.284^{\star \star \star}$ \\
\hline$(0.011)$ & $(0.038)$ & $(0.007)$ & $(0.024)$ & (0.008) & $(0.027)$ \\
\hline $0.153^{\star \star *}$ & $0.143^{\star \star \star}$ & $0.163^{\star \star \star}$ & $0.122^{* * *}$ & $0.205^{\star * \star}$ & $0.205^{\star * \star}$ \\
\hline$(0.012)$ & $(0.042)$ & (0.007) & $(0.025)$ & (0.008) & $(0.026)$ \\
\hline $0.096^{\star * \star}$ & 0.097 & $0.041^{* * *}$ & 0.017 & $0.135^{\star \star *}$ & $0.144^{* * *}$ \\
\hline$(0.015)$ & $(0.058)$ & (0.009) & $(0.031)$ & $(0.009)$ & $(0.030)$ \\
\hline $0.166^{\star \star \star}$ & $0.085^{\star \star \star}$ & $0.213^{\star \star \star}$ & $0.074^{\star \star \star}$ & $0.184^{\star \star \star}$ & $0.081^{\star \star \star}$ \\
\hline$(0.002)$ & $(0.005)$ & $(0.001)$ & $(0.003)$ & $(0.001)$ & $(0.003)$ \\
\hline $0.137^{* * *}$ & $0.175^{\star \star \star}$ & $0.167^{\star \star \star}$ & $0.202^{\star \star \star}$ & $0.185^{\star \star \star}$ & $0.184^{\star \star \star}$ \\
\hline$(0.002)$ & (0.009) & (0.001) & $(0.005)$ & (0.001) & (0.005) \\
\hline$-0.463^{* * *}$ & $-0.250 * \star \star$ & $-0.253^{\star \star \star}$ & $-0.112^{\star \star \star}$ & $-0.036^{\star \star \star}$ & $-0.097^{\star \star \star}$ \\
\hline$(0.012)$ & $(0.031)$ & $(0.009)$ & $(0.025)$ & $(0.008)$ & $(0.022)$ \\
\hline$-0.635^{\star * *}$ & $-0.215^{\star \star \star}$ & $-0.239 * * *$ & 0.020 & $-0.451^{\star \star \star}$ & $0.064^{* \star *}$ \\
\hline$(0.021)$ & $(0.025)$ & $(0.014)$ & $(0.013)$ & (0.015) & $(0.013)$ \\
\hline 7.96E+05 & 77062 & $2.06 \mathrm{E}+06$ & 1.97E+05 & $2.40 \mathrm{E}+06$ & $2.18 \mathrm{E}+05$ \\
\hline
\end{tabular}

Number of Observations

7.96E+05 
Appendix Table 3 cont: Estimated Wage Determinants for Women within and outside Appalachia

Constant

High School

Some College

Bachelors Degree

Masters or more

White, Hispanic

Black, non-Hispanic

Black, Hispanic

Other, non-Hispanic

Other, Hispanic

Potential Experience $>10$ yrs $\&<=20$ yrs

Potential Experience $>20$ yrs \& $<=30$ yrs

Potential Experience $>30$ yrs \& <= 40 yrs

Potential Experience $>40$ yrs

High School x Exper 10-20

High School x Exper 20-30

High School x Exper 30-40

High School x Exper $>40$

$\frac{1980}{\text { Non-Appalachia }}$

1980

on-Appalachia Appalachia Non-Appalachia

1990

\begin{tabular}{|c|c|}
\hline $1.873^{\star \star \star}$ & $1.959 * \star \star$ \\
\hline (0.012) & (0.033) \\
\hline $0.206^{\star * \star}$ & $0.119 * \star *$ \\
\hline (0.011) & (0.033) \\
\hline $0.357^{* * *}$ & $0.319 * * *$ \\
\hline$(0.012)$ & $(0.034)$ \\
\hline $0.568^{\star \star *}$ & $0.578 * \star *$ \\
\hline$(0.012)$ & $(0.034)$ \\
\hline $0.731^{* * *}$ & $0.769 * \star *$ \\
\hline (0.012) & (0.039) \\
\hline$-0.061^{\star \star *}$ & 0.018 \\
\hline (0.004) & $(0.050)$ \\
\hline$-0.017^{\star * *}$ & $-0.081 * * *$ \\
\hline (0.003) & $(0.012)$ \\
\hline-0.035 & -0.157 \\
\hline$(0.030)$ & $(0.159)$ \\
\hline$-0.027^{\star \star \star *}$ & 0.028 \\
\hline$(0.005)$ & $(0.044)$ \\
\hline$-0.075^{\star \star \star}$ & -0.250 \\
\hline (0.016) & $(0.344)$ \\
\hline $0.064^{* * *}$ & (0.031) \\
\hline$(0.012)$ & $(0.034)$ \\
\hline $0.115^{\star \star \star}$ & 0.030 \\
\hline (0.012) & (0.033) \\
\hline $0.138^{\star * *}$ & $0.072^{*}$ \\
\hline$(0.012)$ & (0.033) \\
\hline $0.104^{\star * *}$ & 0.019 \\
\hline$(0.012)$ & $(0.035)$ \\
\hline-0.003 & $0.082^{*}$ \\
\hline (0.012) & (0.035) \\
\hline$-0.030 *$ & 0.058 \\
\hline (0.012) & $(0.035)$ \\
\hline-0.018 & 0.038 \\
\hline (0.012) & $(0.035)$ \\
\hline $0.030 *$ & $0.097^{*}$ \\
\hline$(0.014)$ & $(0.042)$ \\
\hline
\end{tabular}

\begin{tabular}{|c|c|}
\hline on-Appalachia & Appalachia \\
\hline $1.759 * \star \star$ & $1.794^{\star \star \star}$ \\
\hline (0.008) & $(0.023)$ \\
\hline $0.206 * \star \star *$ & $0.168 * \star \star$ \\
\hline (0.007) & $(0.022)$ \\
\hline $0.392^{\star * *}$ & $0.351^{* * *}$ \\
\hline (0.008) & $(0.023)$ \\
\hline $0.698 * * *$ & $0.664^{\star * \star}$ \\
\hline (0.008) & $(0.023)$ \\
\hline $0.891^{* \star *}$ & $0.871^{\star \star \star}$ \\
\hline (0.008) & $(0.025)$ \\
\hline$-0.090^{* * *}$ & -0.032 \\
\hline (0.002) & (0.025) \\
\hline$-0.044^{\star \star *}$ & $-0.057^{* * *}$ \\
\hline$(0.002)$ & $(0.006)$ \\
\hline$-0.066^{\star \star *}$ & -0.138 \\
\hline (0.012) & (0.101) \\
\hline$-0.033^{\star \star *}$ & $-0.050 *$ \\
\hline$(0.002)$ & (0.023) \\
\hline$-0.045^{\star \star \star}$ & 0.248 \\
\hline (0.013) & (0.237) \\
\hline $0.042^{\star \star *}$ & $0.066^{\star *}$ \\
\hline (0.008) & $(0.023)$ \\
\hline $0.124^{\star \star \star}$ & $0.159 * * \star$ \\
\hline (0.008) & $(0.023)$ \\
\hline $0.170 * \star \star$ & $0.213^{\star \star *}$ \\
\hline (0.008) & $(0.022)$ \\
\hline $0.157^{* \star *}$ & $0.237^{\star * *}$ \\
\hline (0.008) & $(0.024)$ \\
\hline $0.049 * * \star$ & 0.033 \\
\hline$(0.008)$ & $(0.024)$ \\
\hline $0.035^{\star \star *}$ & 0.005 \\
\hline$(0.008)$ & $(0.023)$ \\
\hline 0.005 & -0.009 \\
\hline (0.008) & $(0.024)$ \\
\hline 0.016 & -0.021 \\
\hline (0.009) & (0.027) \\
\hline
\end{tabular}

\section{Appalachia}

2000

$\begin{array}{cc}1.779^{\star \star \star} & \text { Appalachia } \\ 1.881^{\star \star \star}\end{array}$

$0.213^{\star \star *} \quad 0.119^{\star \star *}$

(0.009) (0.029)

$0.430 * \star \star \quad 0.293^{\star * *}$

$(0.009) \quad(0.029)$

$0.777^{\star \star \star} \quad 0.609 * \star \star$

(0.009) (0.030)

$0.956^{\star \star *} \quad 0.811^{\star \star *}$

(0.009) (0.031)

$-0.122^{\star \star \star} \quad-0.069^{\star \star}$

(0.002) (0.021)

$-0.045^{\star \star \star} \quad-0.017^{\star \star}$

(0.001) (0.005)

$-0.059 * \star \star \quad 0.031$

(0.011) (0.100)

$-0.063^{\star \star \star} \quad-0.068^{\star \star \star}$

(0.002) (0.014)

$-0.138^{\star \star \star} \quad-0.064^{\star}$

(0.002) (0.028)

$0.036^{\star \star \star} \quad 0.026$

(0.009) (0.029)

0.090 *** $\quad 0.105^{\star \star \star}$

(0.009) (0.029)

$0.108^{* \star *} \quad 0.198^{\star * *}$

$(0.009) \quad(0.030)$

$0.075^{\star \star *} \quad 0.206^{\star \star *}$

$(0.010) \quad(0.032)$

$0.062^{\star \star \star} \quad 0.060$ *

$(0.010) \quad(0.030)$

$0.078^{\star \star \star} \quad 0.070$ *

(0.009) (0.030)

0.069 *** $\quad 0.023$

(0.010) (0.030)

$0.045^{\star \star \star} \quad 0.024$

(0.011) (0.033) 
Appendix Table 3 Women continued 1980

Some College x Exper 10-20

Some College x Exper 20-30

Some College x Exper 30-40

Some College $x$ Exper $>40$

Bachelors x Exper 10-20

Bachelors x Exper 20-30

Bachelors x Exper 30-40

Masters x Exper 10-20

Masters x Exper 20-30

Masters x Exper 30-40

Live in Urban Area

Married

Employment Selection

Migration Selection

Number of Observations

\begin{tabular}{|c|c|c|c|c|c|}
\hline \multicolumn{2}{|c|}{1980} & \multicolumn{2}{|c|}{1990} & \multicolumn{2}{|c|}{2000} \\
\hline Non-Appalachia & Appalachia & Non-Appalachia & Appalachia & Non-Appalachia & Appalachia \\
\hline-0.007 & $0.076^{\star}$ & $0.068^{\star \star \star}$ & $0.059 *$ & $0.080^{\star \star \star}$ & $0.098^{\star \star}$ \\
\hline$(0.013)$ & $(0.038)$ & $(0.008)$ & $(0.024)$ & $(0.009)$ & $(0.030)$ \\
\hline$-0.046^{\star * *}$ & 0.033 & $0.037^{* * *}$ & 0.008 & $0.095^{* * *}$ & $0.114^{* * *}$ \\
\hline$(0.013)$ & $(0.038)$ & $(0.008)$ & $(0.024)$ & $(0.009)$ & $(0.030)$ \\
\hline$-0.047^{* * *}$ & 0.010 & -0.011 & -0.010 & $0.075^{\star * *}$ & 0.045 \\
\hline$(0.013)$ & $(0.040)$ & $(0.008)$ & $(0.024)$ & $(0.009)$ & $(0.030)$ \\
\hline-0.047 & 0.002 & $-0.027^{*}$ & -0.020 & 0.020 & 0.041 \\
\hline$(0.030)$ & (0.093) & $(0.013)$ & $(0.040)$ & $(0.013)$ & $(0.041)$ \\
\hline $0.046^{\star \star \star}$ & $0.143^{\star \star *}$ & $0.063^{\star * \star}$ & $0.071^{* *}$ & $0.099 * * *$ & $0.127^{\star \star *}$ \\
\hline$(0.013)$ & $(0.040)$ & $(0.008)$ & $(0.025)$ & $(0.009)$ & $(0.031)$ \\
\hline $0.031 *$ & $0.098 *$ & -0.003 & 0.005 & $0.046 * * *$ & $0.119 * * *$ \\
\hline (0.013) & $(0.041)$ & $(0.008)$ & $(0.026)$ & $(0.009)$ & $(0.031)$ \\
\hline $0.040 * *$ & $0.109 *$ & $-0.062^{\star * *}$ & -0.019 & -0.006 & 0.005 \\
\hline$(0.015)$ & $(0.047)$ & $(0.009)$ & $(0.030)$ & $(0.010)$ & $(0.033)$ \\
\hline $0.099 * * *$ & 0.091 & $0.114^{\star \star \star}$ & $0.108^{\star \star \star}$ & $0.142^{\star \star \star}$ & $0.170^{\star \star *}$ \\
\hline$(0.015)$ & $(0.050)$ & (0.009) & $(0.027)$ & $(0.010)$ & $(0.032)$ \\
\hline $0.114^{* * *}$ & 0.050 & $0.053^{\star * *}$ & 0.045 & $0.113^{\star * *}$ & $0.161^{* \star *}$ \\
\hline$(0.016)$ & (0.055) & $(0.009)$ & $(0.028)$ & $(0.010)$ & $(0.032)$ \\
\hline $0.151^{\star \star \star}$ & 0.123 & $0.023^{\star}$ & 0.026 & $0.050 * * *$ & 0.007 \\
\hline (0.019) & $(0.070)$ & $(0.010)$ & $(0.034)$ & $(0.010)$ & $(0.035)$ \\
\hline $0.163^{\star \star \star}$ & $0.070 * \star \star$ & $0.237^{* * *}$ & $0.083^{* * *}$ & $0.208^{* * *}$ & $0.092^{* * *}$ \\
\hline$(0.002)$ & $(0.005)$ & $(0.001)$ & $(0.003)$ & $(0.001)$ & $(0.003)$ \\
\hline$-0.033^{\star \star \star}$ & 0.011 & $-0.020 * * *$ & $0.010^{\star \star}$ & $-0.020 * \star *$ & $0.025^{\star \star \star}$ \\
\hline$(0.002)$ & $(0.007)$ & $(0.001)$ & (0.003) & $(0.001)$ & $(0.003)$ \\
\hline 0.006 & -0.026 & $0.025^{\star * *}$ & $-0.067^{* \star *}$ & $0.237^{* * *}$ & -0.001 \\
\hline$(0.006)$ & $(0.016)$ & $(0.004)$ & (0.013) & $(0.005)$ & $(0.016)$ \\
\hline 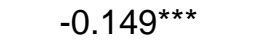 & $-0.112^{\star \star *}$ & $0.055^{\star * *}$ & $0.059 * * *$ & $-0.313^{\star * *}$ & $0.120 * \star \star$ \\
\hline$(0.026)$ & $(0.030)$ & $(0.015)$ & $(0.014)$ & $(0.016)$ & $(0.014)$ \\
\hline $6.56 \mathrm{E}+05$ & 60450 & $1.93 E+06$ & 1.83E+05 & $2.28 \mathrm{E}+06$ & $2.09 E+05$ \\
\hline
\end{tabular}




\begin{tabular}{|c|c|c|c|c|}
\hline & \multicolumn{4}{|c|}{1980} \\
\hline & \multicolumn{2}{|c|}{ Non-Appalachia } & \multicolumn{2}{|c|}{ Appalachia } \\
\hline & Employment & Stayer & Employment & Stayer \\
\hline \multirow{2}{*}{ High School } & $0.390^{\star \star \star}$ & $0.106^{\star \star}$ & $0.376^{\star \star \star}$ & $-0.134^{\star}$ \\
\hline & $(0.022)$ & $(0.041)$ & $(0.074)$ & $(0.062)$ \\
\hline \multirow[t]{2}{*}{ Some College } & $0.415^{\star \star \star}$ & -0.017 & $0.467^{* * *}$ & $-0.397 * \star \star *$ \\
\hline & $(0.022)$ & $(0.040)$ & $(0.081)$ & $(0.064)$ \\
\hline \multirow[t]{2}{*}{ Bachelors Degree } & $0.674^{\star \star \star}$ & $-0.301^{\star \star \star}$ & $0.898^{* \star \star}$ & $-0.576^{\star \star \star}$ \\
\hline & $(0.023)$ & $(0.039)$ & $(0.090)$ & $(0.063)$ \\
\hline \multirow[t]{2}{*}{ Masters or more } & $0.349^{\star \star \star}$ & $-0.305^{\star \star \star}$ & $0.390 * \star \star$ & $-0.847^{\star \star \star}$ \\
\hline & $(0.024)$ & $(0.040)$ & $(0.100)$ & $(0.067)$ \\
\hline \multirow[t]{2}{*}{ White, Hispanic } & $-0.193^{\star \star *}$ & $0.423^{\star \star *}$ & $-0.247^{* *}$ & -0.120 \\
\hline & $(0.009)$ & $(0.038)$ & (0.095) & (0.083) \\
\hline \multirow[t]{2}{*}{ Black, non-Hispanic } & $-0.431^{\star * *}$ & $0.383^{* * *}$ & $-0.128^{* * *}$ & $0.091^{\star *}$ \\
\hline & $(0.006)$ & $(0.017)$ & $(0.026)$ & $(0.029)$ \\
\hline \multirow[t]{2}{*}{ Black, Hispanic } & $-0.456^{\star \star \star}$ & 0.259 & -0.194 & -0.309 \\
\hline & $(0.045)$ & $(0.147)$ & $(0.262)$ & $(0.285)$ \\
\hline \multirow[t]{2}{*}{ Other, non-Hispanic } & $-0.352^{\star \star \star}$ & $-0.072^{*}$ & $-0.278^{*}$ & $-0.552^{\star \star \star}$ \\
\hline & $(0.012)$ & $(0.032)$ & (0.122) & $(0.066)$ \\
\hline \multirow[t]{2}{*}{ Other, Hispanic } & $-0.210 * \star \star *$ & $0.257^{*}$ & 0.614 & 0.053 \\
\hline & $(0.031)$ & (0.124) & (0.582) & $(0.286)$ \\
\hline \multirow{2}{*}{ Potential Experience $>10$ yrs \& $<=20$ yrs } & $-0.234^{\star \star \star}$ & $0.131^{\star *}$ & $-0.353^{\star \star *}$ & $0.155^{\star}$ \\
\hline & $(0.021)$ & $(0.042)$ & $(0.071)$ & $(0.064)$ \\
\hline \multirow[t]{2}{*}{ Potential Experience $>20$ yrs \& $<=30$ yrs } & $-0.370 * \star \star$ & $0.368^{\star \star *}$ & $-0.581^{\star * *}$ & $0.246^{\star \star *}$ \\
\hline & $(0.021)$ & $(0.044)$ & $(0.071)$ & $(0.065)$ \\
\hline \multirow[t]{2}{*}{ Potential Experience $>30$ yrs $\&<=40$ yrs } & $-0.548^{\star \star *}$ & $0.510^{\star * *}$ & $-0.780 * \star \star$ & $0.470 * * *$ \\
\hline & $(0.021)$ & $(0.043)$ & $(0.070)$ & $(0.065)$ \\
\hline \multirow[t]{2}{*}{ Potential Experience $>40$ yrs } & $-0.907^{\star * *}$ & $0.673^{\star * \star}$ & $-1.216^{\star \star *}$ & $0.564^{* * *}$ \\
\hline & $(0.021)$ & $(0.047)$ & $(0.070)$ & $(0.067)$ \\
\hline \multirow[t]{2}{*}{ High School x Exper 10-20 } & 0.035 & -0.058 & $0.195^{\star}$ & 0.059 \\
\hline & $(0.025)$ & $(0.046)$ & $(0.081)$ & $(0.070)$ \\
\hline \multirow{2}{*}{ High School x Exper 20-30 } & -0.005 & $-0.141^{\star *}$ & $0.199^{*}$ & 0.036 \\
\hline & $(0.025)$ & $(0.049)$ & $(0.081)$ & $(0.071)$ \\
\hline \multirow[t]{2}{*}{ High School x Exper 30-40 } & $-0.177^{\star * \star}$ & -0.098 & 0.009 & 0.041 \\
\hline & $(0.024)$ & $(0.050)$ & $(0.079)$ & $(0.074)$ \\
\hline \multirow[t]{2}{*}{ High School x Exper $>40$} & $-0.179 * \star \star$ & $-0.215^{\star \star}$ & 0.058 & 0.033 \\
\hline & $(0.027)$ & $(0.071)$ & $(0.087)$ & $(0.100)$ \\
\hline Some College x Exper 10-20 & $0.111^{* * *}$ & -0.035 & 0.139 & -0.011 \\
\hline & $(0.026)$ & $(0.047)$ & $(0.094)$ & $(0.073)$ \\
\hline Some College x Exper 20-30 & 0.017 & -0.101 & 0.086 & 0.075 \\
\hline & $(0.026)$ & $(0.052)$ & $(0.097)$ & $(0.079)$ \\
\hline Some College x Exper 30-40 & $-0.195^{\star \star \star}$ & -0.069 & -0.073 & 0.012 \\
\hline & $(0.025)$ & $(0.055)$ & $(0.094)$ & $(0.084)$ \\
\hline Some College $x$ Exper $>40$ & $-0.171^{\star *}$ & -0.203 & -0.253 & 0.380 \\
\hline & $(0.060)$ & (0.183) & $(0.234)$ & $(0.365)$ \\
\hline Bachelors x Exper 10-20 & 0.032 & $0.119 * *$ & -0.013 & 0.011 \\
\hline & $(0.029)$ & $(0.046)$ & $(0.120)$ & $(0.074)$ \\
\hline Bachelors x Exper 20-30 & -0.055 & $0.122^{*}$ & -0.021 & $0.266^{* \star *}$ \\
\hline & $(0.029)$ & (0.051) & $(0.117)$ & $(0.080)$ \\
\hline Bachelors x Exper 30-40 & $-0.281^{\star \star *}$ & $0.168^{\star \star}$ & $-0.252^{\star}$ & $0.217^{\star}$ \\
\hline & $(0.028)$ & $(0.057)$ & (0.111) & $(0.088)$ \\
\hline Masters x Exper 10-20 & $0.366^{\star * *}$ & $0.118^{*}$ & $0.486^{\star \star *}$ & $0.357^{* * *}$ \\
\hline & $(0.033)$ & $(0.050)$ & $(0.145)$ & $(0.083)$ \\
\hline
\end{tabular}




\begin{tabular}{|c|c|c|c|c|}
\hline Masters x Exper 20-30 & $\begin{array}{c}0.268^{\star \star \star} \\
(0.033)\end{array}$ & $\begin{array}{l}0.127^{*} \\
(0.058)\end{array}$ & $\begin{array}{l}0.342^{*} \\
(0.135)\end{array}$ & $\begin{array}{c}0.571^{\star \star \star} \\
(0.093)\end{array}$ \\
\hline \multirow[t]{2}{*}{ Masters x Exper 30-40 } & 0.064 & 0.064 & 0.251 & $0.620^{* \star *}$ \\
\hline & $(0.036)$ & $(0.075)$ & $(0.154)$ & $(0.131)$ \\
\hline \multirow[t]{2}{*}{ Live in Urban Area } & $0.165^{\star \star \star}$ & $0.038^{\star \star \star}$ & $0.174^{\star \star \star}$ & $0.033^{\star}$ \\
\hline & (0.005) & (0.010) & (0.015) & (0.014) \\
\hline \multirow[t]{2}{*}{ Married } & $0.503^{\star \star \star}$ & $-0.041^{* \star *}$ & $0.679 * \star *$ & 0.019 \\
\hline & $(0.006)$ & $(0.012)$ & $(0.018)$ & $(0.019)$ \\
\hline \multirow[t]{2}{*}{ State Unemployment Rate } & $-0.044^{\star \star \star}$ & 0.005 & $-0.036^{\star \star \star}$ & $0.130 * * *$ \\
\hline & $(0.002)$ & $(0.005)$ & $(0.009)$ & $(0.008)$ \\
\hline \multirow[t]{2}{*}{ Combined SSI-Food Stamp Guarantee } & $-0.100 * \star *$ & 0.015 & $0.489^{\star * \star}$ & $-0.184^{\star * *}$ \\
\hline & $(0.006)$ & $(0.016)$ & $(0.062)$ & $(0.056)$ \\
\hline \multirow[t]{2}{*}{ Combined AFDC-Food Stamp Guarantee } & $0.001 * \star \star$ & $0.002^{* \star *}$ & 0.000 & $0.001^{\star \star *}$ \\
\hline & 0.000 & 0.000 & 0.000 & 0.000 \\
\hline \multirow[t]{2}{*}{ Governor is a Democrat } & $-0.077^{\star \star \star}$ & $-0.021^{*}$ & $-0.044^{\star \star}$ & $-0.081^{\star \star \star}$ \\
\hline & $(0.005)$ & $(0.009)$ & $(0.015)$ & $(0.014)$ \\
\hline \multirow[t]{2}{*}{ State Minimum Wage } & $0.799 * \star \star$ & $-0.938^{\star \star \star}$ & & \\
\hline & $(0.109)$ & $(0.222)$ & & \\
\hline \multirow[t]{2}{*}{ EITC Phase-in Rate } & $237.127^{\star \star \star}$ & $-82.333^{\star \star \star}$ & $314.939 * \star \star$ & $73.631^{\star \star}$ \\
\hline & $(7.867)$ & $(15.561)$ & (23.718) & (23.679) \\
\hline \multirow[t]{2}{*}{ Nonlabor Income (\$1000s) } & $-0.011^{\star \star \star}$ & $0.002^{\star \star \star}$ & $-0.013^{\star \star \star}$ & $0.003^{* * *}$ \\
\hline & 0.000 & 0.000 & 0.000 & 0.000 \\
\hline \multirow[t]{2}{*}{ Number of Children } & -0.001 & $-0.040^{* \star *}$ & $-0.037^{\star \star \star}$ & $-0.018^{\star}$ \\
\hline & $(0.003)$ & $(0.006)$ & $(0.008)$ & $(0.009)$ \\
\hline \multirow[t]{2}{*}{ Number of Children under Age 5} & $-0.123^{\star \star \star}$ & $-0.020^{\star}$ & $-0.125^{\star \star \star}$ & $-0.093^{\star * \star}$ \\
\hline & $(0.006)$ & $(0.009)$ & $(0.019)$ & $(0.013)$ \\
\hline \multirow[t]{2}{*}{ Born in Appalachia } & & $-0.707^{\star \star \star}$ & & $0.917^{* * *}$ \\
\hline & & $(0.009)$ & & $(0.019)$ \\
\hline \multirow[t]{2}{*}{ Constant } & $-0.781^{*}$ & $4.266^{\star \star \star}$ & 0.098 & -0.129 \\
\hline & $(0.311)$ & $(0.633)$ & $(0.161)$ & $(0.147)$ \\
\hline Number of Observations & 843000 & 854000 & 78440 & 86872 \\
\hline
\end{tabular}


Appendix Table 4 Men Continued

\begin{tabular}{|c|c|c|c|c|}
\hline \multicolumn{5}{|c|}{1990} \\
\hline & \multicolumn{2}{|c|}{ Non-Appalachia } & \multicolumn{2}{|c|}{ Appalachia } \\
\hline & Employment & Stayer & Employment & Stayer \\
\hline \multirow[t]{2}{*}{ High School } & $0.425^{\star \star \star}$ & -0.031 & $0.465^{\star \star \star}$ & $-0.152^{\star \star \star}$ \\
\hline & $(0.014)$ & $(0.034)$ & $(0.044)$ & $(0.044)$ \\
\hline \multirow[t]{2}{*}{ Some College } & $0.631^{\star \star \star}$ & $-0.162^{\star \star \star}$ & $0.701^{\star * \star}$ & $-0.414^{\star * *}$ \\
\hline & $(0.014)$ & $(0.034)$ & $(0.049)$ & $(0.044)$ \\
\hline \multirow[t]{2}{*}{ Bachelors Degree } & $0.774^{\star * *}$ & $-0.429 * * *$ & 0.930 *** & $-0.643^{\star \star *}$ \\
\hline & $(0.015)$ & $(0.033)$ & $(0.056)$ & $(0.045)$ \\
\hline \multirow[t]{2}{*}{ Masters or more } & $0.547^{* * *}$ & $-0.444^{\star \star \star}$ & $0.742^{\star \star \star}$ & $-0.841^{\star \star \star}$ \\
\hline & $(0.017)$ & $(0.034)$ & $(0.073)$ & $(0.048)$ \\
\hline \multirow[t]{2}{*}{ White, Hispanic } & $-0.062^{\star \star *}$ & $0.277^{* \star *}$ & 0.092 & $-0.563^{\star \star \star}$ \\
\hline & $(0.005)$ & $(0.019)$ & $(0.073)$ & $(0.040)$ \\
\hline \multirow{2}{*}{ Black, non-Hispanic } & $-0.407^{* \star *}$ & $0.323^{\star \star \star}$ & $-0.219 * \star \star *$ & 0.023 \\
\hline & $(0.004)$ & $(0.010)$ & $(0.016)$ & $(0.018)$ \\
\hline \multirow[t]{2}{*}{ Black, Hispanic } & $-0.424^{\star \star \star}$ & $0.199 *$ & -0.440 & -0.333 \\
\hline & $(0.024)$ & (0.095) & $(0.311)$ & $(0.251)$ \\
\hline \multirow[t]{2}{*}{ Other, non-Hispanic } & $-0.388^{\star \star \star}$ & -0.029 & $-0.243^{\star \star \star}$ & $-0.387^{\star \star *}$ \\
\hline & $(0.006)$ & (0.018) & $(0.054)$ & $(0.035)$ \\
\hline \multirow{2}{*}{ Other, Hispanic } & $-0.140 * \star \star$ & $0.725^{\star \star}$ & -0.527 & -0.403 \\
\hline & $(0.032)$ & $(0.265)$ & $(0.404)$ & $(0.270)$ \\
\hline \multirow[t]{2}{*}{ Potential Experience $>10$ yrs $\&<=20$ yrs } & $-0.172^{\star \star \star}$ & 0.022 & $-0.306^{\star \star \star}$ & 0.036 \\
\hline & $(0.014)$ & $(0.035)$ & $(0.042)$ & $(0.045)$ \\
\hline \multirow[t]{2}{*}{ Potential Experience $>20$ yrs $\&<=30$ yrs } & $-0.374^{\star \star \star}$ & $0.180^{\star \star \star}$ & $-0.577^{\star \star \star}$ & $0.188^{\star \star \star}$ \\
\hline & $(0.014)$ & $(0.036)$ & $(0.042)$ & $(0.046)$ \\
\hline \multirow[t]{2}{*}{ Potential Experience $>30$ yrs $\&<=40$ yrs } & $-0.527^{\star \star \star}$ & $0.348^{\star \star \star}$ & $-0.712^{\star \star \star}$ & $0.281^{\star \star \star}$ \\
\hline & $(0.014)$ & $(0.037)$ & $(0.042)$ & $(0.046)$ \\
\hline \multirow[t]{2}{*}{ Potential Experience $>40$ yrs } & $-0.856^{\star \star \star}$ & $0.377^{\star \star \star}$ & $-1.105^{\star \star \star}$ & $0.326^{\star \star \star}$ \\
\hline & $(0.014)$ & $(0.038)$ & $(0.042)$ & $(0.047)$ \\
\hline \multirow{2}{*}{ High School x Exper 10-20 } & -0.004 & $0.103^{\star \star}$ & $0.104^{*}$ & $0.135^{\star \star}$ \\
\hline & $(0.015)$ & $(0.038)$ & $(0.048)$ & $(0.048)$ \\
\hline \multirow[t]{2}{*}{ High School x Exper 20-30 } & -0.021 & 0.068 & $0.113^{*}$ & 0.092 \\
\hline & $(0.016)$ & $(0.039)$ & $(0.048)$ & $(0.050)$ \\
\hline \multirow[t]{2}{*}{ High School x Exper 30-40 } & $-0.145^{\star \star *}$ & 0.059 & -0.037 & $0.137^{\star \star *}$ \\
\hline & $(0.015)$ & $(0.041)$ & $(0.047)$ & $(0.051)$ \\
\hline \multirow[t]{2}{*}{ High School x Exper $>40$} & $-0.248^{\star * \star}$ & $0.130^{*}$ & -0.075 & 0.071 \\
\hline & $(0.017)$ & $(0.053)$ & $(0.052)$ & $(0.063)$ \\
\hline Some College x Exper 10-20 & -0.021 & $0.141^{* * *}$ & 0.011 & $0.153^{\star \star}$ \\
\hline & $(0.016)$ & $(0.037)$ & $(0.054)$ & $(0.049)$ \\
\hline Some College x Exper 20-30 & $-0.038^{\star}$ & $0.091^{*}$ & $0.118^{\star}$ & $0.129 *$ \\
\hline & $(0.016)$ & $(0.039)$ & $(0.054)$ & $(0.051)$ \\
\hline Some College x Exper 30-40 & $-0.270 \star \star \star *$ & $0.092^{*}$ & $-0.172^{\star \star}$ & $0.175^{\star \star}$ \\
\hline & $(0.016)$ & $(0.041)$ & $(0.054)$ & $(0.054)$ \\
\hline Some College $x$ Exper $>40$ & $-0.422^{* * *}$ & $0.188^{*}$ & $-0.226^{* *}$ & 0.174 \\
\hline & $(0.024)$ & $(0.079)$ & $(0.083)$ & $(0.100)$ \\
\hline Bachelors x Exper 10-20 & $0.038^{\star}$ & $0.346^{\star \star *}$ & 0.109 & $0.293^{\star \star *}$ \\
\hline & $(0.018)$ & $(0.037)$ & $(0.066)$ & $(0.051)$ \\
\hline Bachelors x Exper 20-30 & 0.001 & $0.331^{\star \star \star}$ & $0.136^{*}$ & $0.235^{\star \star \star}$ \\
\hline & $(0.018)$ & $(0.040)$ & $(0.069)$ & $(0.054)$ \\
\hline Bachelors x Exper 30-40 & $-0.350 * \star \star$ & $0.315^{\star \star \star}$ & $-0.334^{\star \star *}$ & $0.294^{\star \star *}$ \\
\hline & $(0.018)$ & $(0.045)$ & $(0.067)$ & $(0.060)$ \\
\hline Masters x Exper 10-20 & $0.278^{* * *}$ & $0.290^{\star \star \star}$ & $0.302^{* * *}$ & $0.399 * \star \star$ \\
\hline & $(0.020)$ & $(0.039)$ & (0.089) & $(0.055)$ \\
\hline
\end{tabular}




\begin{tabular}{|c|c|c|c|c|}
\hline Masters x Exper 20-30 & $\begin{array}{c}0.280^{\star \star \star} \\
(0.021)\end{array}$ & $\begin{array}{c}0.345^{\star \star \star} \\
(0.042)\end{array}$ & $\begin{array}{l}0.360^{\star \star *} \\
(0.088)\end{array}$ & $\begin{array}{c}0.565^{\star \star \star} \\
(0.060)\end{array}$ \\
\hline Masters x Exper 30-40 & $\begin{array}{c}-0.057^{* *} \\
(0.022)\end{array}$ & $\begin{array}{c}0.289 \star \star \star \\
(0.051)\end{array}$ & $\begin{array}{l}-0.048 \\
(0.091)\end{array}$ & $\begin{array}{c}0.551^{\star \star *} \\
(0.072)\end{array}$ \\
\hline Live in Urban Area & $\begin{array}{c}0.122^{\star \star \star *} \\
(0.003)\end{array}$ & $\begin{array}{c}0.109 * \star \star \\
(0.006)\end{array}$ & $\begin{array}{c}0.092^{\star \star \star} \\
(0.009)\end{array}$ & $\begin{array}{c}-0.042^{\star \star \star} \\
(0.009)\end{array}$ \\
\hline Married & $\begin{array}{c}0.454^{\star \star *} \\
(0.003)\end{array}$ & $\begin{array}{c}-0.040 * \star \star \\
(0.007)\end{array}$ & $\begin{array}{c}0.562^{\star \star \star} \\
(0.011)\end{array}$ & $\begin{array}{l}0.034^{\star *} \\
(0.011)\end{array}$ \\
\hline State Unemployment Rate & $\begin{array}{c}-0.090^{* * *} \\
(0.001)\end{array}$ & $\begin{array}{c}0.060^{\star \star *} \\
(0.003)\end{array}$ & $\begin{array}{c}-0.074^{* * *} \\
(0.003)\end{array}$ & $\begin{array}{l}0.070^{\star * *} \\
(0.004)\end{array}$ \\
\hline Combined SSI-Food Stamp Guarantee & $\begin{array}{c}0.030^{\star \star \star} \\
(0.005)\end{array}$ & $\begin{array}{c}0.083^{\star \star \star} \\
(0.011)\end{array}$ & $\begin{array}{c}0.527^{\star \star \star *} \\
(0.034)\end{array}$ & $\begin{array}{c}-0.078^{\star \star} \\
(0.030)\end{array}$ \\
\hline Combined AFDC-Food Stamp Guarantee & $\begin{array}{c}-0.000 * \star \star \\
0.000\end{array}$ & $\begin{array}{c}0.001^{\star * *} \\
0.000\end{array}$ & $\begin{array}{c}-0.001^{\star * *} \\
0.000\end{array}$ & $\begin{array}{c}0.000^{\star * *} \\
0.000\end{array}$ \\
\hline Governor is a Democrat & $\begin{array}{c}0.025^{\star \star \star} \\
(0.003)\end{array}$ & $\begin{array}{c}-0.154^{\star \star \star} \\
(0.006)\end{array}$ & $\begin{array}{c}-0.100^{\star \star *} \\
(0.013)\end{array}$ & $\begin{array}{c}-0.149^{\star \star \star} \\
(0.012)\end{array}$ \\
\hline State Minimum Wage & $\begin{array}{c}-0.028^{\star \star} \\
(0.009)\end{array}$ & $\begin{array}{c}-0.082^{\star \star \star} \\
(0.020)\end{array}$ & $\begin{array}{c}-0.155^{\star \star \star} \\
(0.033)\end{array}$ & $\begin{array}{c}0.948^{\star \star \star} \\
(0.031)\end{array}$ \\
\hline EITC Phase-in Rate & $\begin{array}{c}222.621^{* * *} \\
(3.575)\end{array}$ & $\begin{array}{c}-22.357^{\star *} \\
(7.341)\end{array}$ & $\begin{array}{c}223.671^{\star * *} \\
(10.746)\end{array}$ & $\begin{array}{c}128.823^{\star \star \star} \\
(10.671)\end{array}$ \\
\hline Nonlabor Income (\$1000s) & $\begin{array}{c}-0.005^{\star \star \star} \\
0.000\end{array}$ & $\begin{array}{c}0.002^{\star * \star} \\
0.000\end{array}$ & $\begin{array}{c}-0.006^{\star \star \star} \\
0.000\end{array}$ & $\begin{array}{c}0.002^{* \star *} \\
0.000\end{array}$ \\
\hline Number of Children & $\begin{array}{c}0.000 \\
(0.002)\end{array}$ & $\begin{array}{c}-0.052^{\star \star \star} \\
(0.004)\end{array}$ & $\begin{array}{l}-0.016^{\star} \\
(0.007)\end{array}$ & $\begin{array}{c}-0.025^{\star \star \star} \\
(0.007)\end{array}$ \\
\hline Number of Children under Age 5 & $\begin{array}{c}-0.052^{\star \star \star} \\
(0.003)\end{array}$ & $\begin{array}{l}-0.011 \\
(0.006)\end{array}$ & $\begin{array}{c}-0.066^{* * *} \\
(0.011)\end{array}$ & $\begin{array}{c}-0.159 * \star \star \\
(0.008)\end{array}$ \\
\hline Born in Appalachia & & $\begin{array}{c}-0.646^{\star * \star} \\
(0.006)\end{array}$ & & $\begin{array}{c}0.887^{\star * \star} \\
(0.010)\end{array}$ \\
\hline Constant & $\begin{array}{c}1.615^{\star \star *} \\
(0.023)\end{array}$ & $\begin{array}{c}1.413^{\star \star *} \\
(0.059)\end{array}$ & $\begin{array}{l}-0.094 \\
(0.162)\end{array}$ & $\begin{array}{c}-2.828^{* \star *} \\
(0.155)\end{array}$ \\
\hline Number of Observations & 2190000 & 2210000 & 202000 & 224000 \\
\hline
\end{tabular}


Appendix Table 4 Men Continued

\begin{tabular}{|c|c|c|c|c|}
\hline \multicolumn{5}{|c|}{2000} \\
\hline & \multicolumn{2}{|c|}{ Non-Appalachia } & \multicolumn{2}{|c|}{ Appalachia } \\
\hline & Employment & Stayer & Employment & Stayer \\
\hline \multirow[t]{2}{*}{ High School } & $0.333^{\star \star \star}$ & -0.012 & $0.558^{\star \star \star}$ & -0.003 \\
\hline & $(0.015)$ & $(0.038)$ & $(0.048)$ & $(0.049)$ \\
\hline \multirow[t]{2}{*}{ Some College } & $0.652^{* \star *}$ & $-0.120 * \star$ & $0.918 * * *$ & $-0.274^{\star \star \star}$ \\
\hline & $(0.015)$ & $(0.037)$ & $(0.051)$ & $(0.049)$ \\
\hline \multirow[t]{2}{*}{ Bachelors Degree } & $0.801^{* * *}$ & $-0.382^{\star * \star}$ & $1.033^{\star \star *}$ & $-0.528^{\star \star \star}$ \\
\hline & $(0.016)$ & $(0.037)$ & $(0.056)$ & $(0.049)$ \\
\hline \multirow[t]{2}{*}{ Masters or more } & $0.638 * * *$ & $-0.409 * \star \star$ & $1.010^{\star * *}$ & $-0.848^{\star \star \star}$ \\
\hline & $(0.017)$ & $(0.038)$ & $(0.076)$ & $(0.052)$ \\
\hline \multirow[t]{2}{*}{ White, Hispanic } & $-0.064^{\star \star \star}$ & $0.216^{\star * *}$ & $0.174^{\star * *}$ & $-0.653^{\star \star \star}$ \\
\hline & $(0.005)$ & $(0.017)$ & $(0.048)$ & $(0.028)$ \\
\hline \multirow[t]{2}{*}{ Black, non-Hispanic } & $-0.423^{\star * *}$ & $0.237^{\star * \star}$ & $-0.273^{\star \star \star}$ & $-0.184^{\star \star \star}$ \\
\hline & $(0.003)$ & $(0.009)$ & $(0.014)$ & $(0.014)$ \\
\hline \multirow[t]{2}{*}{ Black, Hispanic } & $-0.347^{* * *}$ & 0.117 & -0.226 & $-0.646^{* * *}$ \\
\hline & $(0.021)$ & $(0.071)$ & (0.179) & $(0.129)$ \\
\hline \multirow[t]{2}{*}{ Other, non-Hispanic } & $-0.301^{\star * *}$ & $-0.130 * \star \star$ & $-0.257^{* * *}$ & $-0.541^{\star \star \star}$ \\
\hline & $(0.004)$ & $(0.011)$ & $(0.030)$ & $(0.021)$ \\
\hline \multirow[t]{2}{*}{ Other, Hispanic } & $-0.028^{\star * *}$ & $0.186^{\star \star \star}$ & $0.354^{\star \star *}$ & $-0.823^{\star \star \star}$ \\
\hline & $(0.005)$ & $(0.018)$ & $(0.054)$ & $(0.027)$ \\
\hline \multirow[t]{2}{*}{ Potential Experience $>10$ yrs $\&<=20$ yrs } & $-0.120 * * *$ & 0.029 & $-0.139 * *$ & 0.069 \\
\hline & $(0.015)$ & $(0.039)$ & $(0.048)$ & $(0.050)$ \\
\hline \multirow[t]{2}{*}{ Potential Experience $>20$ yrs \& $<=30$ yrs } & $-0.310^{\star \star \star}$ & $0.168^{\star \star \star}$ & $-0.413^{\star * *}$ & $0.206^{\star \star *}$ \\
\hline & $(0.015)$ & $(0.039)$ & $(0.047)$ & $(0.050)$ \\
\hline \multirow[t]{2}{*}{ Potential Experience $>30$ yrs $\&<=40$ yrs } & $-0.543^{\star \star \star}$ & $0.313^{\star \star \star}$ & $-0.691 * \star \star$ & $0.354^{\star \star \star}$ \\
\hline & $(0.015)$ & $(0.040)$ & $(0.047)$ & $(0.051)$ \\
\hline \multirow[t]{2}{*}{ Potential Experience $>40$ yrs } & $-0.820 * \star \star$ & $0.437^{* * *}$ & $-1.002^{\star \star \star}$ & $0.430 * \star *$ \\
\hline & $(0.015)$ & $(0.043)$ & $(0.047)$ & $(0.053)$ \\
\hline \multirow[t]{2}{*}{ High School x Exper 10-20 } & 0.024 & $0.081^{*}$ & -0.017 & 0.049 \\
\hline & $(0.016)$ & $(0.041)$ & $(0.052)$ & $(0.053)$ \\
\hline \multirow[t]{2}{*}{ High School x Exper 20-30 } & $0.036^{*}$ & $0.106^{*}$ & 0.024 & 0.061 \\
\hline & $(0.016)$ & $(0.042)$ & $(0.051)$ & $(0.054)$ \\
\hline \multirow[t]{2}{*}{ High School x Exper 30-40 } & $-0.051^{* *}$ & $0.120^{* *}$ & -0.048 & -0.005 \\
\hline & $(0.016)$ & $(0.043)$ & $(0.051)$ & $(0.055)$ \\
\hline \multirow[t]{2}{*}{ High School x Exper $>40$} & $-0.117^{\star \star *}$ & 0.008 & -0.101 & $-0.148^{\star}$ \\
\hline & $(0.018)$ & $(0.054)$ & $(0.055)$ & $(0.065)$ \\
\hline Some College $x$ Exper $10-20$ & 0.000 & $0.157^{\star \star \star}$ & -0.077 & 0.087 \\
\hline & $(0.017)$ & $(0.041)$ & $(0.057)$ & $(0.053)$ \\
\hline Some College x Exper 20-30 & $-0.077^{\star * \star}$ & $0.165^{\star \star \star}$ & $-0.110^{*}$ & $0.143^{\star \star}$ \\
\hline & $(0.016)$ & $(0.041)$ & $(0.055)$ & $(0.054)$ \\
\hline Some College $x$ Exper 30-40 & $-0.209 * \star \star *$ & $0.157^{* \star *}$ & $-0.213^{\star \star *}$ & 0.049 \\
\hline & $(0.016)$ & $(0.043)$ & $(0.055)$ & $(0.055)$ \\
\hline Some College $x$ Exper $>40$ & $-0.377^{\star \star \star}$ & $0.156^{*}$ & $-0.351^{\star \star *}$ & -0.046 \\
\hline & $(0.022)$ & $(0.075)$ & $(0.074)$ & $(0.087)$ \\
\hline Bachelors x Exper 10-20 & $0.044^{*}$ & $0.320 * \star \star$ & 0.061 & $0.153^{\star *}$ \\
\hline & $(0.018)$ & $(0.041)$ & $(0.067)$ & $(0.055)$ \\
\hline Bachelors x Exper 20-30 & 0.003 & $0.388^{\star \star \star}$ & -0.003 & $0.301^{\star * *}$ \\
\hline & $(0.017)$ & $(0.041)$ & $(0.062)$ & $(0.055)$ \\
\hline Bachelors x Exper 30-40 & 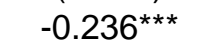 & $0.350 * \star \star$ & $-0.136^{*}$ & $0.193^{\star *}$ \\
\hline & $(0.018)$ & $(0.045)$ & $(0.063)$ & $(0.059)$ \\
\hline Masters x Exper 10-20 & $0.197^{\star * *}$ & $0.249 * \star \star$ & 0.055 & $0.399 * \star \star$ \\
\hline & $(0.020)$ & $(0.042)$ & $(0.091)$ & $(0.059)$ \\
\hline
\end{tabular}




\begin{tabular}{|c|c|c|c|c|}
\hline Masters x Exper 20-30 & $\begin{array}{c}0.214^{\star \star \star} \\
(0.019)\end{array}$ & $\begin{array}{c}0.330^{\star \star \star} \\
(0.043)\end{array}$ & $\begin{array}{l}0.202^{\star} \\
(0.084)\end{array}$ & $\begin{array}{c}0.597^{\star \star \star} \\
(0.059)\end{array}$ \\
\hline Masters x Exper 30-40 & $\begin{array}{l}-0.030 \\
(0.020)\end{array}$ & $\begin{array}{l}0.325^{\star \star \star} \\
(0.048)\end{array}$ & $\begin{array}{l}-0.182^{*} \\
(0.084)\end{array}$ & $\begin{array}{c}0.581^{\star \star \star} \\
(0.066)\end{array}$ \\
\hline Live in Urban Area & $\begin{array}{c}0.148^{\star \star \star} \\
(0.003)\end{array}$ & $\begin{array}{c}0.027^{\star \star \star} \\
(0.006)\end{array}$ & $\begin{array}{c}0.150^{\star * *} \\
(0.007)\end{array}$ & $\begin{array}{l}0.017^{\star} \\
(0.008)\end{array}$ \\
\hline Married & $\begin{array}{c}0.411^{\star \star \star} \\
(0.003)\end{array}$ & $\begin{array}{c}-0.023^{\star \star *} \\
(0.006)\end{array}$ & $\begin{array}{c}0.502^{\star \star \star} \\
(0.009)\end{array}$ & $\begin{array}{c}0.058^{\star \star \star} \\
(0.009)\end{array}$ \\
\hline State Unemployment Rate & $\begin{array}{c}-0.088^{* * *} \\
(0.002)\end{array}$ & $\begin{array}{l}0.020^{* * *} \\
(0.004)\end{array}$ & $\begin{array}{c}-0.115^{\star \star *} \\
(0.005)\end{array}$ & $\begin{array}{c}0.063^{\star * *} \\
(0.006)\end{array}$ \\
\hline Combined SSI-Food Stamp Guarantee & $\begin{array}{c}0.016^{\star \star \star} \\
(0.003)\end{array}$ & $\begin{array}{l}0.174^{\star \star \star} \\
(0.011)\end{array}$ & $\begin{array}{c}0.689 * \star \star \\
(0.031)\end{array}$ & $\begin{array}{c}-0.112^{\star \star \star} \\
(0.033)\end{array}$ \\
\hline Combined AFDC-Food Stamp Guarantee & $\begin{array}{c}-0.000^{* * *} \\
0.000\end{array}$ & $\begin{array}{c}0.001^{\star * *} \\
0.000\end{array}$ & $\begin{array}{c}-0.001^{\star \star \star} \\
0.000\end{array}$ & $\begin{array}{l}0.000 \\
0.000\end{array}$ \\
\hline Governor is a Democrat & $\begin{array}{c}0.011^{\star \star \star} \\
(0.003)\end{array}$ & $\begin{array}{c}-0.137^{\star \star \star} \\
(0.006)\end{array}$ & $\begin{array}{c}-0.027^{\star \star} \\
(0.009)\end{array}$ & $\begin{array}{c}-0.176^{\star \star \star} \\
(0.009)\end{array}$ \\
\hline State Minimum Wage & $\begin{array}{c}0.048^{\star \star \star} \\
(0.007)\end{array}$ & $\begin{array}{c}0.249 * \star \star \\
(0.019)\end{array}$ & & \\
\hline EITC Phase-in Rate & $\begin{array}{c}87.638^{\star \star \star} \\
(1.294)\end{array}$ & $\begin{array}{l}7.304^{\star} \\
(2.984)\end{array}$ & $\begin{array}{c}82.966^{\star \star \star} \\
(4.264)\end{array}$ & $\begin{array}{c}66.748^{\star \star \star} \\
(4.201)\end{array}$ \\
\hline Nonlabor Income (\$1000s) & $\begin{array}{c}-0.003^{\star \star \star} \\
0.000\end{array}$ & $\begin{array}{c}0.001^{\star \star \star} \\
0.000\end{array}$ & $\begin{array}{c}-0.005^{\star \star \star} \\
0.000\end{array}$ & $\begin{array}{c}0.000^{\star \star \star} \\
0.000\end{array}$ \\
\hline Number of Children & $\begin{array}{l}-0.002 \\
(0.002)\end{array}$ & $\begin{array}{c}-0.032^{\star * \star} \\
(0.005)\end{array}$ & $\begin{array}{c}0.000 \\
(0.008)\end{array}$ & $\begin{array}{c}-0.042^{\star \star \star} \\
(0.007)\end{array}$ \\
\hline Number of Children under Age 5 & $\begin{array}{c}-0.013^{\star \star \star} \\
(0.003)\end{array}$ & $\begin{array}{c}-0.033^{\star \star \star} \\
(0.006)\end{array}$ & $\begin{array}{l}0.023^{*} \\
(0.012)\end{array}$ & $\begin{array}{c}-0.119 * \star \star \\
(0.008)\end{array}$ \\
\hline Born in Appalachia & & $\begin{array}{c}-0.626^{\star * *} \\
(0.006)\end{array}$ & & $\begin{array}{c}0.783^{\star * \star} \\
(0.009)\end{array}$ \\
\hline Constant & $\begin{array}{c}0.960^{\star * *} \\
(0.032)\end{array}$ & $\begin{array}{c}-0.439 * * * \\
(0.095)\end{array}$ & $\begin{array}{c}-2.761^{\star * *} \\
(0.182)\end{array}$ & $\begin{array}{c}0.994^{\star \star \star} \\
(0.189)\end{array}$ \\
\hline Number of Observations & 2630000 & 2660000 & 234000 & 262000 \\
\hline
\end{tabular}


Appendix Table 5: First Stage Estimates of the Probability of Employment and Staying in Region for Women, 1980-2000

\begin{tabular}{|c|c|c|c|c|}
\hline & \multicolumn{4}{|c|}{1980} \\
\hline & \multicolumn{2}{|c|}{ Non-Appalachia } & \multicolumn{2}{|c|}{ Appalachia } \\
\hline & Employment & Stayer & Employment & Stayer \\
\hline \multirow[t]{2}{*}{ High School } & $0.479 * \star \star$ & -0.062 & $0.381^{\star \star \star}$ & -0.031 \\
\hline & $(0.015)$ & $(0.041)$ & $(0.045)$ & $(0.056)$ \\
\hline \multirow[t]{2}{*}{ Some College } & $0.719 * \star \star *$ & $-0.188^{\star \star \star}$ & $0.719 * * \star$ & $-0.348^{\star \star *}$ \\
\hline & $(0.015)$ & $(0.042)$ & $(0.049)$ & $(0.058)$ \\
\hline \multirow{2}{*}{ Bachelors Degree } & 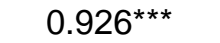 & $-0.365^{\star \star \star}$ & $1.101^{\star \star \star}$ & $-0.499 \star \star \star$ \\
\hline & $(0.015)$ & $(0.041)$ & $(0.052)$ & $(0.057)$ \\
\hline \multirow[t]{2}{*}{ Masters or more } & $1.030 * * *$ & $-0.312^{\star \star \star}$ & $1.277^{\star \star \star}$ & $-0.567^{\star \star *}$ \\
\hline & $(0.019)$ & $(0.044)$ & $(0.076)$ & $(0.067)$ \\
\hline \multirow[t]{2}{*}{ White, Hispanic } & $-0.087^{* * *}$ & $0.486^{\star \star \star}$ & -0.037 & $-0.188^{\star}$ \\
\hline & $(0.006)$ & $(0.038)$ & $(0.070)$ & (0.078) \\
\hline \multirow[t]{2}{*}{ Black, non-Hispanic } & $-0.024^{\star \star \star}$ & $0.439 * \star \star$ & $0.091^{* * *}$ & $0.174^{\star \star *}$ \\
\hline & $(0.005)$ & $(0.015)$ & $(0.018)$ & $(0.027)$ \\
\hline \multirow[t]{2}{*}{ Black, Hispanic } & $-0.178^{\star \star \star}$ & $0.399 * *$ & -0.100 & 0.106 \\
\hline & $(0.033)$ & $(0.142)$ & $(0.182)$ & $(0.275)$ \\
\hline \multirow[t]{2}{*}{ Other, non-Hispanic } & $0.019^{*}$ & -0.039 & 0.010 & $-0.469 * \star \star$ \\
\hline & $(0.008)$ & $(0.030)$ & $(0.071)$ & $(0.059)$ \\
\hline \multirow[t]{2}{*}{ Other, Hispanic } & -0.001 & $0.314^{*}$ & -0.083 & $-1.027^{\star \star \star}$ \\
\hline & $(0.023)$ & $(0.127)$ & $(0.370)$ & $(0.247)$ \\
\hline \multirow[t]{2}{*}{ Potential Experience $>10$ yrs $\&<=20$ yrs } & $-0.094^{\star \star \star}$ & 0.029 & $-0.167^{\star \star *}$ & 0.062 \\
\hline & $(0.015)$ & $(0.043)$ & $(0.045)$ & $(0.057)$ \\
\hline \multirow[t]{2}{*}{ Potential Experience $>20$ yrs $\&<=30$ yrs } & $-0.164^{\star \star \star}$ & $0.235^{\star \star \star}$ & $-0.284^{\star * *}$ & $0.250 * \star *$ \\
\hline & $(0.015)$ & $(0.044)$ & $(0.045)$ & $(0.058)$ \\
\hline \multirow[t]{2}{*}{ Potential Experience $>30$ yrs $\&<=40$ yrs } & $-0.423^{\star \star \star}$ & $0.456^{\star \star \star}$ & $-0.528 * \star \star$ & $0.539 * * \star$ \\
\hline & $(0.014)$ & $(0.044)$ & $(0.044)$ & $(0.058)$ \\
\hline \multirow[t]{2}{*}{ Potential Experience $>40$ yrs } & $-0.762^{\star \star \star}$ & $0.454^{\star * *}$ & $-0.921 * \star \star$ & $0.535^{\star \star *}$ \\
\hline & $(0.015)$ & $(0.046)$ & $(0.045)$ & $(0.060)$ \\
\hline \multirow[t]{2}{*}{ High School x Exper 10-20 } & $-0.097^{\star \star *}$ & 0.068 & -0.006 & -0.014 \\
\hline & $(0.016)$ & $(0.046)$ & $(0.049)$ & $(0.062)$ \\
\hline \multirow[t]{2}{*}{ High School x Exper 20-30 } & $-0.087^{\star * \star}$ & 0.088 & $0.102^{*}$ & 0.047 \\
\hline & $(0.016)$ & $(0.048)$ & $(0.049)$ & $(0.064)$ \\
\hline \multirow[t]{2}{*}{ High School x Exper 30-40 } & $-0.178^{\star \star \star}$ & 0.040 & -0.014 & 0.006 \\
\hline & $(0.016)$ & $(0.049)$ & $(0.048)$ & $(0.066)$ \\
\hline \multirow[t]{2}{*}{ High School x Exper $>40$} & $-0.167^{\star \star \star}$ & 0.010 & 0.079 & -0.003 \\
\hline & $(0.018)$ & $(0.060)$ & $(0.057)$ & $(0.087)$ \\
\hline Some College x Exper $10-20$ & $-0.186^{\star \star \star}$ & $0.111^{*}$ & $-0.120^{*}$ & 0.041 \\
\hline & $(0.017)$ & $(0.047)$ & $(0.057)$ & $(0.066)$ \\
\hline Some College x Exper 20-30 & $-0.197^{* \star *}$ & $0.133^{\star *}$ & -0.094 & $0.192^{\star \star}$ \\
\hline & $(0.017)$ & $(0.051)$ & $(0.059)$ & $(0.073)$ \\
\hline Some College $x$ Exper 30-40 & $-0.369 * \star \star$ & $0.121^{*}$ & $-0.259 * * \star$ & $0.178^{\star}$ \\
\hline & $(0.017)$ & (0.054) & $(0.059)$ & $(0.078)$ \\
\hline Some College $x$ Exper $>40$ & $-0.327^{\star \star \star}$ & -0.052 & -0.064 & $0.807^{\star}$ \\
\hline & $(0.042)$ & $(0.136)$ & $(0.164)$ & $(0.398)$ \\
\hline Bachelors x Exper 10-20 & $-0.266^{\star \star \star}$ & $0.273^{\star \star \star}$ & $-0.307^{\star \star \star}$ & $0.220 * \star$ \\
\hline & $(0.018)$ & $(0.048)$ & $(0.063)$ & $(0.070)$ \\
\hline Bachelors x Exper 20-30 & $-0.295^{\star \star *}$ & $0.294^{\star \star \star}$ & $-0.241^{* * *}$ & $0.463^{\star \star *}$ \\
\hline & $(0.019)$ & $(0.054)$ & $(0.067)$ & $(0.081)$ \\
\hline Bachelors x Exper 30-40 & $-0.463^{\star \star \star}$ & $0.376^{\star \star \star}$ & $-0.538^{\star \star \star}$ & $0.382^{* * *}$ \\
\hline & $(0.020)$ & $(0.066)$ & $(0.069)$ & $(0.095)$ \\
\hline Masters x Exper 10-20 & 0.036 & $0.296^{\star \star \star}$ & 0.078 & $0.429 * \star \star$ \\
\hline & $(0.026)$ & $(0.061)$ & $(0.112)$ & $(0.098)$ \\
\hline
\end{tabular}




\begin{tabular}{|c|c|c|c|c|}
\hline Masters x Exper 20-30 & $\begin{array}{l}-0.042 \\
(0.028)\end{array}$ & $\begin{array}{c}0.357^{\star \star \star} \\
(0.077)\end{array}$ & $\begin{array}{l}-0.167 \\
(0.112)\end{array}$ & $\begin{array}{c}0.524^{\star \star \star} \\
(0.116)\end{array}$ \\
\hline Masters x Exper 30-40 & $-0.219^{\star \star \star}$ & $0.337^{* *}$ & $-0.382^{\star *}$ & $0.615^{\star \star}$ \\
\hline & $(0.034)$ & $(0.121)$ & $(0.136)$ & $(0.195)$ \\
\hline Live in Urban Area & $\begin{array}{c}0.083^{\star \star \star} \\
(0.003)\end{array}$ & $\begin{array}{c}0.003 \\
(0.010)\end{array}$ & $\begin{array}{c}0.049 * \star \star \\
(0.009)\end{array}$ & $\begin{array}{l}-0.003 \\
(0.013)\end{array}$ \\
\hline Married & $\begin{array}{c}-0.199^{* * *} \\
(0.004)\end{array}$ & $\begin{array}{c}-0.036^{* * *} \\
(0.011)\end{array}$ & $\begin{array}{c}-0.204^{\star * *} \\
(0.012)\end{array}$ & $\begin{array}{c}0.026 \\
(0.017)\end{array}$ \\
\hline State Unemployment Rate & $\begin{array}{c}-0.046^{\star \star \star} \\
(0.001)\end{array}$ & $\begin{array}{l}0.013^{\star *} \\
(0.004)\end{array}$ & $\begin{array}{c}-0.120^{\star \star \star} \\
(0.006)\end{array}$ & $\begin{array}{c}0.133^{\star \star \star} \\
(0.008)\end{array}$ \\
\hline Combined SSI-Food Stamp Guarantee & $\begin{array}{c}0.015^{\star \star *} \\
(0.004)\end{array}$ & $\begin{array}{c}0.013 \\
(0.015)\end{array}$ & $\begin{array}{c}0.815^{\star \star *} \\
(0.041)\end{array}$ & $\begin{array}{c}-0.238^{\star \star *} \\
(0.053)\end{array}$ \\
\hline Combined AFDC-Food Stamp Guarantee & $\begin{array}{c}-0.000^{* \star \star} \\
0.000\end{array}$ & $\begin{array}{c}0.002^{\star \star \star} \\
0.000\end{array}$ & $\begin{array}{c}-0.001^{\star \star \star} \\
0.000\end{array}$ & $\begin{array}{c}0.001^{\star \star \star} \\
0.000\end{array}$ \\
\hline Governor is a Democrat & $\begin{array}{c}-0.022^{\star \star \star} \\
(0.003)\end{array}$ & $\begin{array}{c}-0.039^{* \star *} \\
(0.009)\end{array}$ & $\begin{array}{c}0.055^{\star \star \star} \\
(0.010)\end{array}$ & $\begin{array}{c}-0.088^{\star \star \star} \\
(0.013)\end{array}$ \\
\hline State Minimum Wage & $\begin{array}{c}0.631^{\star \star *} \\
(0.069)\end{array}$ & $\begin{array}{c}-1.113^{\star \star \star} \\
(0.218)\end{array}$ & & \\
\hline EITC Phase-in Rate & $\begin{array}{c}38.966^{\star * \star} \\
(4.479)\end{array}$ & $\begin{array}{c}-66.291^{\text {*** }} \\
(13.069)\end{array}$ & $\begin{array}{c}122.000^{\star * \star} \\
(14.384)\end{array}$ & $\begin{array}{c}32.663 \\
(20.393)\end{array}$ \\
\hline Nonlabor Income (\$1000s) & $\begin{array}{c}-0.007^{\star \star \star} \\
0.000\end{array}$ & $\begin{array}{l}0.000 \\
0.000\end{array}$ & $\begin{array}{c}-0.007^{\star \star \star} \\
0.000\end{array}$ & $\begin{array}{l}0.000 \\
0.000\end{array}$ \\
\hline Number of Children & $\begin{array}{c}-0.065^{\star \star \star} \\
(0.002)\end{array}$ & $\begin{array}{c}-0.041^{\star * *} \\
(0.005)\end{array}$ & $\begin{array}{c}-0.060^{\star \star *} \\
(0.005)\end{array}$ & $\begin{array}{c}0.000 \\
(0.008)\end{array}$ \\
\hline Number of Children under Age 5 & $\begin{array}{c}-0.478^{\star * *} \\
(0.003)\end{array}$ & $\begin{array}{c}-0.036^{\star * *} \\
(0.008)\end{array}$ & $\begin{array}{c}-0.452^{\star * *} \\
(0.011)\end{array}$ & $\begin{array}{c}-0.123^{\star \star *} \\
(0.013)\end{array}$ \\
\hline Born in Appalachia & & $\begin{array}{c}-0.675^{\star \star \star} \\
(0.009)\end{array}$ & & $\begin{array}{c}0.867^{\star \star \star} \\
(0.017)\end{array}$ \\
\hline Constant & $\begin{array}{c}-0.816^{\star \star *} \\
(0.197)\end{array}$ & $\begin{array}{l}4.902^{\star \star *} \\
(0.622)\end{array}$ & $\begin{array}{c}-0.312^{\star *} \\
(0.104)\end{array}$ & $\begin{array}{c}0.100 \\
(0.138)\end{array}$ \\
\hline Number of Observations & 1010000 & 1020000 & 96098 & 105000 \\
\hline
\end{tabular}


Appendix Table 5 Women Continued

\begin{tabular}{|c|c|c|c|c|}
\hline \multicolumn{5}{|c|}{1990} \\
\hline & \multicolumn{2}{|c|}{ Non-Appalachia } & \multicolumn{2}{|c|}{ Appalachia } \\
\hline & Employment & Stayer & Employment & Stayer \\
\hline \multirow[t]{2}{*}{ High School } & $0.537^{\star \star \star}$ & 0.038 & $0.580^{\star \star \star *}$ & $0.113^{\star \star}$ \\
\hline & $(0.011)$ & $(0.032)$ & $(0.034)$ & $(0.041)$ \\
\hline \multirow[t]{2}{*}{ Some College } & $0.904^{\star * *}$ & $-0.067^{*}$ & $1.012^{\star \star \star}$ & -0.059 \\
\hline & $(0.011)$ & $(0.031)$ & $(0.036)$ & $(0.041)$ \\
\hline \multirow[t]{2}{*}{ Bachelors Degree } & $1.136^{\star \star \star}$ & $-0.283^{\star \star \star}$ & $1.284^{\star * \star}$ & 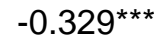 \\
\hline & $(0.012)$ & $(0.031)$ & $(0.039)$ & $(0.041)$ \\
\hline \multirow[t]{2}{*}{ Masters or more } & $1.176^{\star * *}$ & $-0.270^{\star \star \star}$ & $1.437^{* * *}$ & $-0.317^{* * *}$ \\
\hline & $(0.014)$ & (0.033) & $(0.050)$ & $(0.046)$ \\
\hline \multirow[t]{2}{*}{ White, Hispanic } & $-0.095^{\star \star \star}$ & $0.344^{\star * \star}$ & -0.086 & $-0.506^{\star * \star}$ \\
\hline & $(0.003)$ & $(0.020)$ & $(0.049)$ & $(0.040)$ \\
\hline \multirow[t]{2}{*}{ Black, non-Hispanic } & $-0.092^{\star \star \star}$ & $0.415^{\star \star \star}$ & $0.059 * \star \star$ & $0.055^{\star \star}$ \\
\hline & $(0.003)$ & $(0.010)$ & $(0.013)$ & $(0.017)$ \\
\hline \multirow[t]{2}{*}{ Black, Hispanic } & $-0.252^{\star \star \star}$ & $0.368^{\star \star \star}$ & -0.236 & $-0.492^{\star}$ \\
\hline & $(0.019)$ & $(0.105)$ & $(0.260)$ & $(0.239)$ \\
\hline \multirow[t]{2}{*}{ Other, non-Hispanic } & $-0.181^{\star \star \star}$ & -0.030 & $-0.177^{\star \star *}$ & $-0.433^{\star * *}$ \\
\hline & $(0.004)$ & $(0.017)$ & $(0.037)$ & $(0.032)$ \\
\hline \multirow[t]{2}{*}{ Other, Hispanic } & -0.033 & 0.256 & -0.378 & -0.341 \\
\hline & $(0.023)$ & $(0.131)$ & $(0.256)$ & $(0.210)$ \\
\hline \multirow[t]{2}{*}{ Potential Experience $>10 \mathrm{yrs} \&<=20 \mathrm{yrs}$} & $-0.034^{* *}$ & $0.094^{\star *}$ & -0.046 & 0.160 *** \\
\hline & $(0.011)$ & $(0.033)$ & $(0.034)$ & $(0.042)$ \\
\hline \multirow[t]{2}{*}{ Potential Experience $>20$ yrs $\&<=30$ yrs } & $-0.075^{\star \star \star}$ & $0.239 * \star \star$ & $-0.158^{\star \star \star}$ & $0.321^{\star \star *}$ \\
\hline & $(0.011)$ & $(0.034)$ & $(0.034)$ & $(0.043)$ \\
\hline \multirow[t]{2}{*}{ Potential Experience $>30$ yrs \& $<=40$ yrs } & $-0.286^{\star \star \star}$ & $0.413^{\star \star \star}$ & $-0.405^{\star \star \star}$ & $0.495^{\star \star \star}$ \\
\hline & $(0.011)$ & $(0.034)$ & $(0.034)$ & $(0.043)$ \\
\hline \multirow[t]{2}{*}{ Potential Experience $>40$ yrs } & $-0.619 * \star \star$ & $0.525^{\star \star \star}$ & $-0.736^{\star \star \star}$ & $0.599 * * *$ \\
\hline & $(0.011)$ & $(0.037)$ & $(0.035)$ & $(0.045)$ \\
\hline \multirow[t]{2}{*}{ High School x Exper 10-20 } & $-0.043^{\star \star \star}$ & 0.007 & -0.049 & -0.078 \\
\hline & $(0.012)$ & $(0.036)$ & $(0.037)$ & $(0.046)$ \\
\hline \multirow[t]{2}{*}{ High School x Exper 20-30 } & $-0.049 * * *$ & 0.012 & -0.035 & -0.052 \\
\hline & $(0.012)$ & $(0.037)$ & $(0.037)$ & $(0.047)$ \\
\hline \multirow[t]{2}{*}{ High School x Exper 30-40 } & $-0.216^{\star \star \star}$ & 0.016 & $-0.146 * \star \star$ & $-0.106^{*}$ \\
\hline & $(0.012)$ & $(0.037)$ & $(0.037)$ & $(0.047)$ \\
\hline \multirow[t]{2}{*}{ High School x Exper $>40$} & $-0.262^{\star \star \star}$ & -0.021 & $-0.188^{\star \star \star}$ & 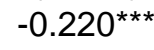 \\
\hline & $(0.013)$ & $(0.046)$ & $(0.041)$ & $(0.057)$ \\
\hline Some College $x$ Exper 10-20 & $-0.139 * \star \star$ & 0.040 & $-0.137^{\star \star \star}$ & $-0.094^{\star}$ \\
\hline & $(0.012)$ & $(0.035)$ & (0.039) & $(0.046)$ \\
\hline Some College x Exper 20-30 & $-0.150 * \star \star$ & 0.039 & $-0.086^{*}$ & -0.069 \\
\hline & $(0.012)$ & $(0.036)$ & $(0.040)$ & $(0.048)$ \\
\hline Some College $x$ Exper 30-40 & $-0.366^{\star * \star}$ & 0.057 & $-0.318^{\star * *}$ & $-0.118^{*}$ \\
\hline & $(0.012)$ & $(0.039)$ & $(0.040)$ & $(0.050)$ \\
\hline Some College $x$ Exper $>40$ & $-0.478^{\star \star *}$ & 0.154 & $-0.401^{\star \star \star}$ & -0.129 \\
\hline & $(0.019)$ & $(0.080)$ & $(0.067)$ & $(0.097)$ \\
\hline Bachelors x Exper 10-20 & $-0.258^{\star \star \star}$ & $0.248^{\star \star \star}$ & $-0.215^{\star \star \star}$ & $0.136^{\star \star}$ \\
\hline & $(0.013)$ & $(0.036)$ & $(0.045)$ & $(0.048)$ \\
\hline Bachelors x Exper 20-30 & $-0.291 * \star \star$ & $0.309 * * \star$ & $-0.281^{* * *}$ & $0.177^{\star \star \star}$ \\
\hline & $(0.014)$ & $(0.039)$ & $(0.048)$ & $(0.053)$ \\
\hline Bachelors x Exper 30-40 & $-0.586 * \star \star$ & $0.275^{\star \star \star}$ & $-0.613^{\star \star \star}$ & $0.164^{* \star}$ \\
\hline & $(0.014)$ & $(0.045)$ & $(0.051)$ & $(0.062)$ \\
\hline Masters x Exper 10-20 & 0.001 & $0.254^{\star \star \star}$ & 0.033 & $0.254^{\star \star *}$ \\
\hline & $(0.016)$ & $(0.038)$ & $(0.059)$ & $(0.054)$ \\
\hline
\end{tabular}




\begin{tabular}{|c|c|c|c|c|}
\hline Masters x Exper 20-30 & $\begin{array}{l}-0.033 \\
(0.017)\end{array}$ & $\begin{array}{c}0.350^{\star \star \star} \\
(0.044)\end{array}$ & $\begin{array}{l}-0.108 \\
(0.062)\end{array}$ & $\begin{array}{c}0.328^{\star \star \star} \\
(0.061)\end{array}$ \\
\hline Masters x Exper 30-40 & $-0.364^{\star \star \star}$ & $0.282^{\star \star \star}$ & $-0.430^{\star \star *}$ & $0.171^{*}$ \\
\hline & $(0.019)$ & $(0.058)$ & $(0.072)$ & $(0.082)$ \\
\hline Live in Urban Area & $\begin{array}{c}0.044^{\star \star \star} \\
(0.002)\end{array}$ & $\begin{array}{c}0.089 * \star \star \\
(0.006)\end{array}$ & $\begin{array}{c}0.025^{\star \star *} \\
(0.007)\end{array}$ & $\begin{array}{c}-0.049 * * \star \\
(0.008)\end{array}$ \\
\hline Married & $\begin{array}{c}-0.088^{\star * * *} \\
(0.002)\end{array}$ & $\begin{array}{c}-0.027^{\star * *} \\
(0.006)\end{array}$ & $\begin{array}{c}-0.069 * * * \\
(0.007)\end{array}$ & $\begin{array}{c}0.078^{\star \star \star *} \\
(0.009)\end{array}$ \\
\hline State Unemployment Rate & $\begin{array}{c}-0.081^{\star \star *} \\
(0.001)\end{array}$ & $\begin{array}{c}0.053^{\star \star \star} \\
(0.003)\end{array}$ & $\begin{array}{c}-0.092^{\star \star \star} \\
(0.003)\end{array}$ & $\begin{array}{c}0.070^{\star \star \star} \\
(0.004)\end{array}$ \\
\hline Combined SSI-Food Stamp Guarantee & $\begin{array}{c}-0.002 \\
(0.003)\end{array}$ & $\begin{array}{c}0.089 * \star \star \\
(0.011)\end{array}$ & $\begin{array}{c}0.437^{\star \star *} \\
(0.024)\end{array}$ & $\begin{array}{l}-0.062^{*} \\
(0.029)\end{array}$ \\
\hline Combined AFDC-Food Stamp Guarantee & $\begin{array}{l}-0.000^{\star \star \star *} \\
0.000\end{array}$ & $\begin{array}{c}0.001^{\star \star \star} \\
0.000\end{array}$ & $\begin{array}{c}-0.001^{\star \star \star} \\
0.000\end{array}$ & $\begin{array}{c}0.000^{\star \star \star \star} \\
0.000\end{array}$ \\
\hline Governor is a Democrat & $\begin{array}{l}0.006^{\star \star *} \\
(0.002)\end{array}$ & $\begin{array}{c}-0.131^{\star \star \star} \\
(0.006)\end{array}$ & $\begin{array}{c}-0.087^{\star * \star} \\
(0.009)\end{array}$ & $\begin{array}{c}-0.138^{\star \star \star} \\
(0.011)\end{array}$ \\
\hline State Minimum Wage & $\begin{array}{c}0.025^{\star \star \star} \\
(0.006)\end{array}$ & $\begin{array}{c}-0.083^{* * *} \\
(0.019)\end{array}$ & $\begin{array}{c}-0.420^{\star \star *} \\
(0.023)\end{array}$ & $\begin{array}{l}0.929 * \star \star \\
(0.030)\end{array}$ \\
\hline EITC Phase-in Rate & $\begin{array}{c}102.044^{\star * *} \\
(2.143)\end{array}$ & $\begin{array}{c}0.129 \\
(6.146)\end{array}$ & $\begin{array}{c}145.952^{\star * \star} \\
(6.930)\end{array}$ & $\begin{array}{c}120.473^{\star \star *} \\
(9.126)\end{array}$ \\
\hline Nonlabor Income (\$1000s) & $\begin{array}{c}-0.004^{\star \star \star} \\
0.000\end{array}$ & $\begin{array}{c}0.000^{\star \star * *} \\
0.000\end{array}$ & $\begin{array}{c}-0.004^{\star \star \star} \\
0.000\end{array}$ & $\begin{array}{c}-0.001^{\star \star \star} \\
0.000\end{array}$ \\
\hline Number of Children & $\begin{array}{c}-0.085^{\star \star \star} \\
(0.001)\end{array}$ & $\begin{array}{c}-0.053^{\star \star *} \\
(0.004)\end{array}$ & $\begin{array}{c}-0.095^{\star \star \star} \\
(0.004)\end{array}$ & $\begin{array}{l}-0.009 \\
(0.006)\end{array}$ \\
\hline Number of Children under Age 5 & $\begin{array}{c}-0.361^{\star * \star} \\
(0.002)\end{array}$ & $\begin{array}{c}-0.025^{\star \star \star} \\
(0.006)\end{array}$ & $\begin{array}{c}-0.341^{\star * *} \\
(0.007)\end{array}$ & $\begin{array}{c}-0.168^{\star \star \star} \\
(0.008)\end{array}$ \\
\hline Born in Appalachia & & $\begin{array}{c}-0.648^{\star \star \star} \\
(0.006)\end{array}$ & & $\begin{array}{c}0.878^{\star \star \star} \\
(0.010)\end{array}$ \\
\hline Constant & $\begin{array}{l}1.089^{\star \star \star} \\
(0.017)\end{array}$ & $\begin{array}{c}1.391^{\star \star \star} \\
(0.057)\end{array}$ & $\begin{array}{c}0.866^{\star \star *} \\
(0.118)\end{array}$ & $\begin{array}{c}-2.966^{\star \star \star} \\
(0.148)\end{array}$ \\
\hline Number of Observations & 2520000 & 2540000 & 237000 & 260000 \\
\hline
\end{tabular}


Appendix Table 5 Women Continued

\begin{tabular}{|c|c|c|c|c|}
\hline \multicolumn{5}{|c|}{2000} \\
\hline & \multicolumn{2}{|c|}{ Non-Appalachia } & \multicolumn{2}{|c|}{ Appalachia } \\
\hline & Employment & Stayer & Employment & Stayer \\
\hline \multirow[t]{2}{*}{ High School } & $0.354^{\star \star \star}$ & -0.031 & $0.442^{\star \star \star}$ & 0.031 \\
\hline & $(0.013)$ & $(0.041)$ & $(0.042)$ & $(0.053)$ \\
\hline \multirow[t]{2}{*}{ Some College } & $0.779 \star \star \star *$ & $-0.112^{\star *}$ & $0.873^{\star \star *}$ & $-0.139 \star *$ \\
\hline & $(0.013)$ & $(0.040)$ & $(0.042)$ & $(0.052)$ \\
\hline \multirow[t]{2}{*}{ Bachelors Degree } & $0.969 * \star \star$ & $-0.308^{\star \star \star}$ & $1.203^{\star \star *}$ & $-0.420 * \star \star *$ \\
\hline & $(0.013)$ & $(0.040)$ & $(0.045)$ & $(0.052)$ \\
\hline \multirow[t]{2}{*}{ Masters or more } & $0.995^{\star * \star}$ & $-0.357^{\star \star \star}$ & $1.382^{\star \star \star}$ & $-0.528 * * *$ \\
\hline & $(0.014)$ & $(0.040)$ & (0.053) & $(0.054)$ \\
\hline \multirow[t]{2}{*}{ White, Hispanic } & $-0.140 * \star \star$ & $0.257^{* * *}$ & -0.017 & $-0.581^{* \star *}$ \\
\hline & $(0.004)$ & $(0.018)$ & $(0.039)$ & $(0.030)$ \\
\hline \multirow[t]{2}{*}{ Black, non-Hispanic } & $-0.080 * \star \star$ & $0.336^{\star * \star}$ & $0.033^{\star \star}$ & $-0.109 * \star \star$ \\
\hline & $(0.003)$ & $(0.008)$ & $(0.011)$ & $(0.013)$ \\
\hline \multirow[t]{2}{*}{ Black, Hispanic } & $-0.178^{\star \star \star}$ & $0.140^{\star}$ & -0.032 & $-0.788^{\star \star \star}$ \\
\hline & $(0.018)$ & $(0.067)$ & (0.147) & $(0.113)$ \\
\hline \multirow[t]{2}{*}{ Other, non-Hispanic } & $-0.203^{\star \star \star}$ & $-0.136^{\star \star \star}$ & $-0.181^{\star \star \star}$ & $-0.521 * \star \star$ \\
\hline & $(0.003)$ & $(0.011)$ & $(0.023)$ & $(0.019)$ \\
\hline \multirow[t]{2}{*}{ Other, Hispanic } & $-0.086^{\star \star \star}$ & $0.313^{\star * \star}$ & 0.017 & $-0.756^{\star \star \star}$ \\
\hline & $(0.004)$ & $(0.020)$ & $(0.047)$ & $(0.033)$ \\
\hline \multirow[t]{2}{*}{ Potential Experience $>10$ yrs $\&<=20$ yrs } & $-0.146 * \star \star$ & 0.022 & $-0.113^{\star \star}$ & 0.043 \\
\hline & $(0.013)$ & $(0.042)$ & $(0.043)$ & $(0.054)$ \\
\hline \multirow[t]{2}{*}{ Potential Experience $>20$ yrs $\&<=30$ yrs } & $-0.198^{\star \star \star}$ & $0.149 * \star \star$ & $-0.307^{\star \star \star}$ & $0.231^{* \star *}$ \\
\hline & $(0.013)$ & $(0.042)$ & $(0.042)$ & $(0.054)$ \\
\hline \multirow[t]{2}{*}{ Potential Experience $>30$ yrs \& $<=40$ yrs } & $-0.388 * * \star$ & $0.276^{\star \star \star}$ & $-0.577^{\star \star \star}$ & $0.348^{\star \star *}$ \\
\hline & $(0.013)$ & $(0.043)$ & $(0.042)$ & $(0.054)$ \\
\hline \multirow[t]{2}{*}{ Potential Experience $>40$ yrs } & $-0.695^{\star \star \star}$ & $0.376^{\star \star \star}$ & $-0.880^{* \star *}$ & $0.411^{* \star *}$ \\
\hline & $(0.013)$ & $(0.045)$ & $(0.043)$ & $(0.056)$ \\
\hline \multirow[t]{2}{*}{ High School x Exper 10-20 } & $0.111^{\star \star *}$ & 0.075 & 0.040 & 0.017 \\
\hline & $(0.014)$ & $(0.045)$ & $(0.046)$ & $(0.057)$ \\
\hline \multirow[t]{2}{*}{ High School x Exper 20-30 } & $0.124^{\star \star \star}$ & $0.109^{*}$ & $0.184^{\star \star \star}$ & 0.015 \\
\hline & $(0.014)$ & $(0.045)$ & $(0.045)$ & $(0.057)$ \\
\hline \multirow[t]{2}{*}{ High School x Exper 30-40 } & $0.044^{\star \star}$ & $0.127^{\star \star}$ & $0.127^{\star *}$ & -0.001 \\
\hline & $(0.014)$ & $(0.046)$ & $(0.045)$ & $(0.058)$ \\
\hline \multirow[t]{2}{*}{ High School x Exper $>40$} & -0.002 & 0.076 & 0.083 & -0.069 \\
\hline & $(0.015)$ & $(0.053)$ & $(0.048)$ & $(0.065)$ \\
\hline Some College x Exper 10-20 & 0.004 & $0.134^{\star \star}$ & -0.017 & 0.019 \\
\hline & $(0.014)$ & $(0.044)$ & $(0.046)$ & $(0.056)$ \\
\hline Some College x Exper 20-30 & -0.016 & $0.174^{\star * \star}$ & 0.079 & 0.024 \\
\hline & $(0.014)$ & $(0.044)$ & $(0.046)$ & $(0.057)$ \\
\hline Some College x Exper 30-40 & $-0.123^{\star \star \star}$ & $0.129 * \star$ & 0.010 & -0.052 \\
\hline & $(0.014)$ & $(0.045)$ & $(0.046)$ & $(0.057)$ \\
\hline Some College $x$ Exper $>40$ & $-0.243^{\star \star \star}$ & 0.074 & -0.037 & -0.037 \\
\hline & $(0.019)$ & $(0.066)$ & $(0.063)$ & $(0.086)$ \\
\hline Bachelors x Exper 10-20 & $-0.117^{\star * \star}$ & $0.302^{\star \star \star}$ & $-0.221^{\star \star \star}$ & $0.199 * \star \star$ \\
\hline & $(0.014)$ & $(0.044)$ & $(0.050)$ & $(0.057)$ \\
\hline Bachelors x Exper 20-30 & $-0.068^{\star * \star}$ & $0.403^{\star \star \star}$ & $-0.118^{*}$ & $0.312^{\star * *}$ \\
\hline & $(0.014)$ & $(0.045)$ & $(0.050)$ & $(0.059)$ \\
\hline Bachelors x Exper 30-40 & $-0.256^{\star \star *}$ & $0.380^{* \star *}$ & $-0.290 * \star \star *$ & $0.197^{* *}$ \\
\hline & $(0.015)$ & $(0.048)$ & $(0.052)$ & $(0.062)$ \\
\hline Masters x Exper 10-20 & $0.091^{\star \star *}$ & $0.333^{\star \star \star}$ & -0.035 & $0.393^{\star * *}$ \\
\hline & $(0.016)$ & $(0.046)$ & $(0.062)$ & $(0.062)$ \\
\hline
\end{tabular}




\begin{tabular}{|c|c|c|c|c|}
\hline Masters x Exper 20-30 & $\begin{array}{c}0.164^{\star \star \star} \\
(0.016)\end{array}$ & $\begin{array}{c}0.452^{\star \star \star} \\
(0.046)\end{array}$ & $\begin{array}{c}0.024 \\
(0.059)\end{array}$ & $\begin{array}{c}0.515^{\star \star \star} \\
(0.062)\end{array}$ \\
\hline Masters x Exper 30-40 & $\begin{array}{c}-0.101^{\star \star \star} \\
(0.017)\end{array}$ & $\begin{array}{c}0.377^{\star \star \star} \\
(0.052)\end{array}$ & $\begin{array}{c}-0.324^{\star \star \star} \\
(0.064)\end{array}$ & $\begin{array}{c}0.413^{\star \star \star} \\
(0.071)\end{array}$ \\
\hline Live in Urban Area & $\begin{array}{c}0.038^{\star \star \star} \\
(0.002)\end{array}$ & $\begin{array}{c}0.007 \\
(0.006)\end{array}$ & $\begin{array}{c}0.055^{\star \star \star} \\
(0.006)\end{array}$ & $\begin{array}{l}0.021^{\star *} \\
(0.007)\end{array}$ \\
\hline Married & $\begin{array}{c}-0.121^{\star \star *} \\
(0.002)\end{array}$ & $\begin{array}{l}0.019 * \star \\
(0.006)\end{array}$ & $\begin{array}{c}-0.035^{* * *} \\
(0.007)\end{array}$ & $\begin{array}{c}0.128^{\star \star *} \\
(0.008)\end{array}$ \\
\hline State Unemployment Rate & $\begin{array}{c}-0.099^{\star * \star} \\
(0.001)\end{array}$ & $\begin{array}{c}0.019 * \star \star \\
(0.004)\end{array}$ & $\begin{array}{c}-0.102^{* * *} \\
(0.004)\end{array}$ & $\begin{array}{c}0.072^{\star \star \star} \\
(0.006)\end{array}$ \\
\hline Combined SSI-Food Stamp Guarantee & $\begin{array}{c}0.025^{\star \star \star} \\
(0.003)\end{array}$ & $\begin{array}{c}0.186^{\star \star \star} \\
(0.011)\end{array}$ & $\begin{array}{c}0.649 \star \star \star \\
(0.025)\end{array}$ & $\begin{array}{c}-0.136^{\star \star \star} \\
(0.032)\end{array}$ \\
\hline Combined AFDC-Food Stamp Guarantee & $\begin{array}{c}-0.000^{\star \star *} \\
0.000\end{array}$ & $\begin{array}{l}0.001^{\star \star *} \\
0.000\end{array}$ & $\begin{array}{c}-0.000^{\star * \star *} \\
0.000\end{array}$ & $\begin{array}{l}0.000 \\
0.000\end{array}$ \\
\hline Governor is a Democrat & $\begin{array}{c}-0.012^{\star \star \star} \\
(0.002)\end{array}$ & $\begin{array}{c}-0.120^{\star \star *} \\
(0.006)\end{array}$ & $\begin{array}{l}-0.008 \\
(0.007)\end{array}$ & $\begin{array}{c}-0.177^{\star \star \star} \\
(0.009)\end{array}$ \\
\hline State Minimum Wage & $\begin{array}{l}0.041^{\star \star \star} \\
(0.005)\end{array}$ & $\begin{array}{c}0.235^{\star \star \star} \\
(0.019)\end{array}$ & & \\
\hline EITC Phase-in Rate & $\begin{array}{c}52.459^{\star \star \star} \\
(0.841)\end{array}$ & $\begin{array}{c}13.094^{\star \star \star} \\
(2.526)\end{array}$ & $\begin{array}{c}72.940 \star \star \star \star \\
(2.895)\end{array}$ & $\begin{array}{c}63.198^{\star \star \star} \\
(3.593)\end{array}$ \\
\hline Nonlabor Income (\$1000s) & $\begin{array}{c}-0.003^{\star \star \star} \\
0.000\end{array}$ & $\begin{array}{l}0.000 \\
0.000\end{array}$ & $\begin{array}{c}-0.003^{\star \star \star} \\
0.000\end{array}$ & $\begin{array}{c}-0.001^{\star \star \star} \\
0.000\end{array}$ \\
\hline Number of Children & $\begin{array}{c}-0.083^{\star \star \star} \\
(0.001)\end{array}$ & $\begin{array}{c}-0.040^{\star \star \star} \\
(0.004)\end{array}$ & $\begin{array}{c}-0.093^{\star * \star} \\
(0.005)\end{array}$ & $\begin{array}{c}-0.034^{\star \star \star} \\
(0.006)\end{array}$ \\
\hline Number of Children under Age 5 & $\begin{array}{c}-0.323^{\star \star *} \\
(0.002)\end{array}$ & $\begin{array}{c}-0.028^{\star * \star} \\
(0.006)\end{array}$ & $\begin{array}{c}-0.321^{* \star *} \\
(0.007)\end{array}$ & $\begin{array}{c}-0.137^{\star * \star} \\
(0.008)\end{array}$ \\
\hline Born in Appalachia & & $\begin{array}{c}-0.616^{\star \star \star} \\
(0.005)\end{array}$ & & $\begin{array}{c}0.781^{\star \star \star} \\
(0.008)\end{array}$ \\
\hline Constant & $\begin{array}{c}0.716^{\star * *} \\
(0.025)\end{array}$ & $\begin{array}{c}-0.401^{* * *} \\
(0.096)\end{array}$ & $\begin{array}{c}-2.811^{* * *} \\
(0.147)\end{array}$ & $\begin{array}{l}1.071^{\star * \star} \\
(0.184)\end{array}$ \\
\hline Number of Observations & 2930000 & 2950000 & 265000 & 293000 \\
\hline
\end{tabular}

